MICHELLE SOPPER

\title{
REGIME JURÍDICO DO BÔNUS DE SUBSCRIÇÃO
}

\author{
Dissertação de Mestrado
}

Orientador: Professor Dr. José Alexandre Tavares Guerreiro

UNIVERSIDADE DE SÃO PAULO

FACULDADE DE DIREITO

São Paulo - SP 


\section{MICHELLE SOPPER}

\section{REGIME JURÍDICO DO BÔNUS DE SUBSCRIÇÃO}

Dissertação apresentada a Banca Examinadora do Programa de Pós Graduação em Direito, da Faculdade de Direito da Universidade de São Paulo, como exigência parcial para obtenção de título de Mestre em Direito, na área de concentração Direito Comercial, sob a orientação do Professor Dr. José Alexandre Tavares Guerreiro.

UNIVERSIDADE DE SÃO PAULO

FACULDADE DE DIREITO

São Paulo - SP

2015 
Agradeço ao meu orientador, Professor Dr. José Alexandre Tavares Guerreiro, por todos os ensinamentos oportunizados, e o apoio fundamental da Juliana Wallauer, da Erica Kisslinger e da Ana Paula Yurgel que fizeram a diferença nessa empreitada.

Em especial, agradeço aos meus pais, Laerte e Karin, pela compreensão e pelo suporte em todos os momentos. 


\section{SUMÁRIO}

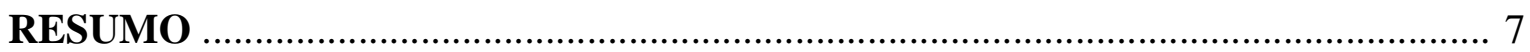

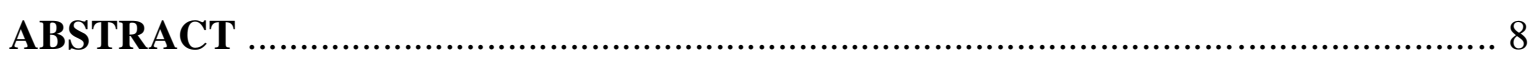

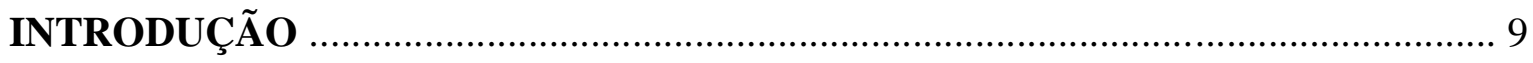

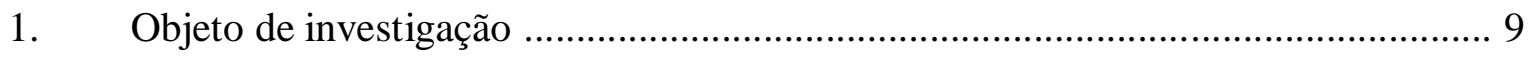

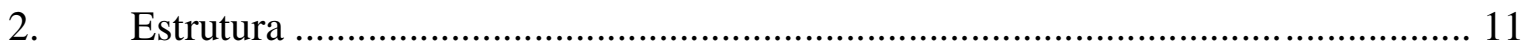

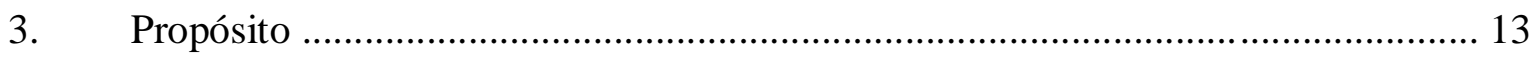

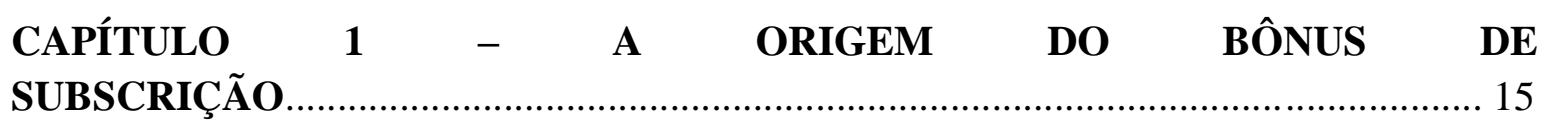

1. Origem do instituto no direito norte-americano ............................................ 15

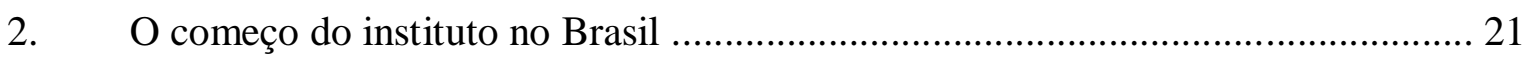

\section{CAPÍTULO 2 - CARACTERIZAÇÃO E NATUREZA JURÍDICA DO BÔNUS DE} SUBSCRIÇÃO

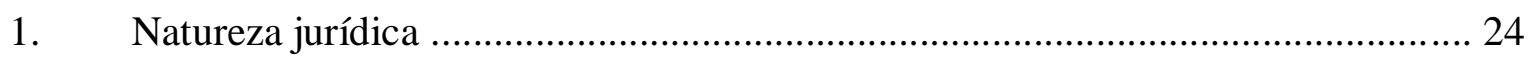

1.1. O bônus de subscrição como valor mobiliário ......................................... 24

1.2. O bônus de subscrição como título de crédito ......................................... 27

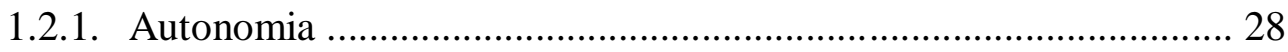

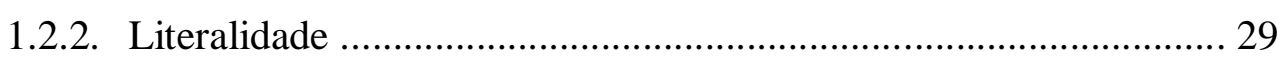

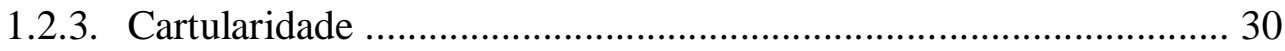

1.2.4. Classificação dos títulos de crédito ............................................ 32

1.3. A dupla natureza jurídica do bônus de subscrição .................................... 33

1.4. Aplicabilidade das disposições do Código Civil ao bônus de subscrição .. 34

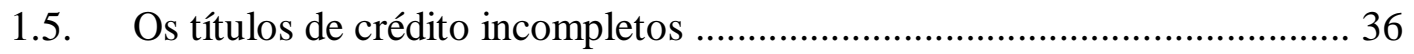


2. Características do bônus de subscrição ................................................................ 41

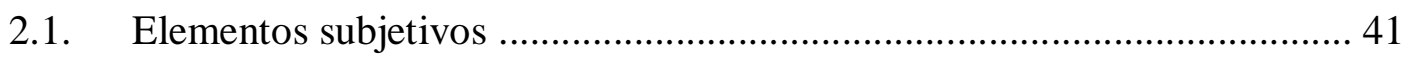

2.1.1. Companhia de capital autorizado ............................................... 42

2.1.2. Assembleia Geral Extraordinária .................................................. 43

2.1.3. Conselho de administração ............................................................. 44

2.1.4. Conselho fiscal ......................................................................... 46

2.1.5. Investidor .............................................................................. 48

2.1.6. Comissão de Valores Mobiliários ..................................................... 48

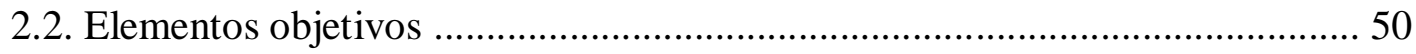

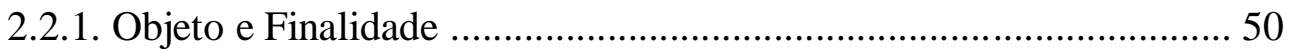

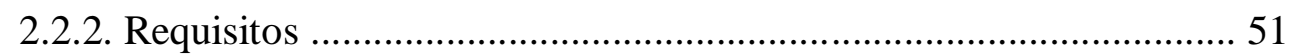

2.2.2.1. Deliberação da assembléia geral ou do conselho de administração ............................................................................ 51

2.2.2.2. Preço de emissão do bônus de subscrição .......................... 52

2.2.2.3. Prazo para exercício do bônus de subscrição ...................... 55

2.2.2.4. Preço de subscrição da ação .............................................. 57

2.2.2.5. Qualificação e quantidade das novas ações ....................... 59

2.2.3. Elementos facultativos do bônus de subscrição .............................. 61

2.2.3.1. Cláusula de ajustamento ..................................................... 61

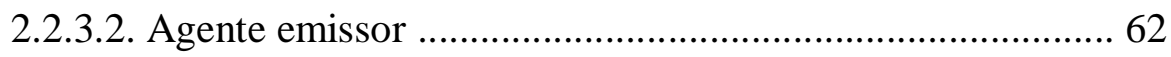

2.2.3.3. Certificado de bônus de subscrição ................................... 63

2.3. Modalidades de emissão do bônus de subscrição ........................................... 64

2.3.1. Emissão para alienação a investidores ............................................. 65

2.3.2. Emissão para atribuição a subscritores de ações ou debêntures ....... 65

2.4. Da negociação e transferência do bônus de subscrição ................................. 66

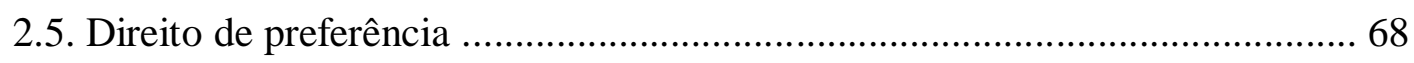

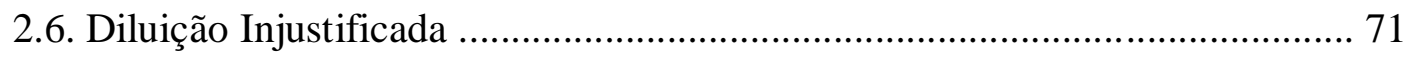

2.7. Restrições à circulação de ações da companhia ............................................... 73

CAPÍTULO 3 - EXERCÍCIO DO BÔNUS DE SUBSCRIÇÃO …............................ 75 
1. Aumento de capital mediante subscrição de ações ...................................................... 76

2. Modalidades de pagamento do preço de subscrição ...................................................... 81

3. Inadimplemento pela companhia: execução específica de obrigação de fazer ............... 82

CAPÍTULO 4 - INSTITUTOS AFINS AO BÔNUS DE SUBSCRIÇÃO .................. 90

1. Opção de compra de ações outorgada a empregados, administradores e prestadores de serviço à companhia 90

2. Opção de compra de ações negociada em bolsa de valores ........................................... 96

3. Debênture conversível em ação .................................................................................. 98

CAPÍTULO 5 - O BÔNUS DE SUBSCRIÇÃO NA PRÁTICA SOCIETÁRIA ...... 104

1. A negociação do bônus de subscrição na BM\&FBovESPA ........................................... 104

2. O uso do bônus de subscrição para manutenção de posição acionária ......................... 107

3. O bônus de subscrição como instrumento de diluiçãa ................................................ 108

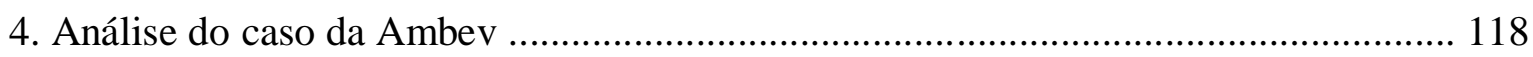

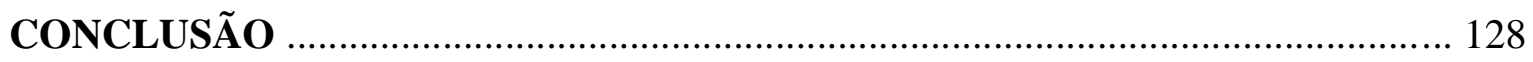

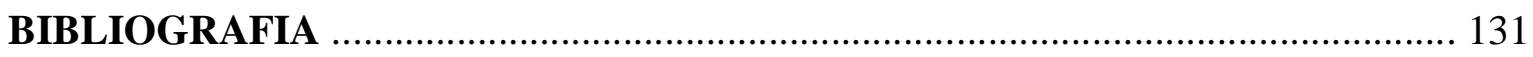

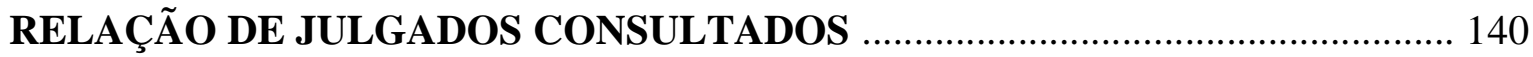




\section{RESUMO}

Michelle Sopper, Regime Jurídico do Bônus de Subscrição, 2015, 140 folhas, Mestrado - Faculdade de Direito, Universidade de São Paulo, São Paulo, 2015.

Este trabalho tem como objeto o estudo do regime jurídico do bônus de subscrição e de sua aplicação na prática societária. $\mathrm{O}$ instituto, que tem sua origem no direito norteamericano, assumiu contornos próprios com a sua introdução no direito brasileiro por meio da Lei $n^{\circ}$ 6.404/1976. O bônus de subscrição consiste em um título negociável emitido por companhia aberta ou fechada em regime de capital autorizado e confere ao seu titular o direito de subscrever ações da sociedade emissora nas condições e no prazo estabelecidos quando da emissão do bônus de subscrição. Na primeira parte do trabalho, foi analisada a natureza jurídica de título de crédito e de valor mobiliário do bônus de subscrição e relacionadas as implicações decorrentes dessa categorização. A seguir, foram traçadas as principais características que moldam o objeto do estudo, bem como dos institutos jurídicos que possuem traços de similaridades no contexto do mercado de capitais. A investigação abrangeu, ainda, os aspectos relacionados ao exercício do bônus de subscrição e a tutela jurisdicional pela execução específica cabível em caso de violação do direito incorporado pelo título. Por fim, foi examinada a aplicação do bônus de subscrição na prática societária por meio do estudo de caso concreto em que a utilização do título suscitou questionamento perante a Comissão de Valores Mobiliários e de negócios jurídicos envolvendo a emissão de bônus de subscrição.

Palavras-chaves: bônus de subscrição - sociedade anônima - regime de capital autorizado - aumento de capital - título de crédito - valor mobiliário 


\section{ABSTRACT}

Michelle Sopper, Regime Jurídico do Bônus de Subscrição, 2015, 140 pages, Master - Faculty of Law, University of São Paulo, São Paulo, 2015.

This study explores the legal framework of stock purchase warrant and its employment in corporate practice. This institution was originatd in the North American Law and took specific outlines with its introduction in Brazilian law by Act 6.404 of 1976. The stock purchase warrant consists of a negotiable instrument issued by open or closed company subject to authorized capital systematic which gives the holder the right to subscribe company's stock under the conditions and term established by its issuance. In the first part of the work, we examined the legal nature of negotiable instument and securities of the stock purchase warrants and related implications arising from such categorization. In the following part, the main features that shape the object of study were outlined, as well as other legal institutions that have similar traces in the capital market context. The study also covered aspects related to the exercise of stock purchase warrants and judicial protection applicable through specific execution in case of violation of the right embodied by the title. Finally, we examined the use of stock purchase warrants in the corporate practice through case brought before the Securities and Exchange Commission and in legal transactions involving the issuance of warrants.

Keywords: stock purchase warrants - corporation - authorized capital - capital raise negotiable instrument - security 


\section{INTRODUÇÃO}

\section{Objeto de investigação}

O objeto do presente estudo é o regime jurídico do bônus de subscrição, o qual abrange os princípios, regras e características que orientam a constituição e a aplicação do bônus de subscrição. Este, por sua vez, corresponde a um título emitido pela sociedade anônima e, nesse contexto, funciona como um instrumento típico da economia moderna cujo principal objetivo é auxiliar na realização da atividade produtiva. Por meio deste tipo societário, a companhia - para usar a terminologia da Lei de Sociedades Anônimas ${ }^{1}$ - é que se estabelece (i) a responsabilidade limitada dos sócios, a qual decorre da existência distinta da pessoa jurídica da de seus membros, e (ii) a divisão do capital da sociedade em participações cuja titularidade pode ser negociada. Com base nesses pressupostos, a sociedade anônima capta recursos para o financiamento de sua atividade ${ }^{2}$.

Diante das necessidades impostas pelo desenvolvimento de sua operação, a sociedade anônima tem evoluído em complexidade e, ao longo dos anos, tem sido aparelhada de institutos que lhe conferem o dinamismo necessário para acompanhar a evolução do mercado. Sob o aspecto da captação de recursos, a sociedade anônima dispõe de diferentes mecanismos, os quais não se restringem apenas ao aporte inicial realizado quando da sua fundação.

$\mathrm{Na}$ constituição da companhia, os acionistas fundadores contribuem com dinheiro ou bens suscetíveis de avaliação em espécie e recebem ações que representam parte do capital social da sociedade. Frequentemente, esse primeiro investimento é insuficiente para atender a todas as necessidades da empresa, de modo que, ao longo de sua existência, a companhia demanda novas entradas de recursos para que atinja e expanda seus objetivos.

Posteriormente à constituição, a capitalização da companhia pode se dar a partir de

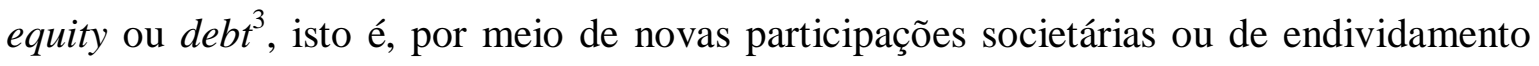

\footnotetext{
${ }^{1}$ Neste estudo, todas as referências à "Lei de Sociedades Anônimas" ou "lei acionária" dizem respeito à Lei $\mathrm{n}^{\mathrm{o}}$ 6.404/76. E, considerando que o trabalho trata sobre regime jurídico conferido ao bônus de subscrição pela Lei de Sociedades Anônimas, todos os dispositivos citados neste trabalho se referem à Lei ${ }^{\circ}$ 6.404/76, exceto quando expressamente indicado outro texto normativo

${ }^{2}$ ASCARELLI, Tullio. Problemas das Sociedades Anônimas e Direito Comparado. São Paulo: Saraiva, 1945, p. 335.

${ }^{3}$ ROMANO, Roberta. Foundations of Corporate Law. New York: Foundation Press, 1993, p. 119.
} 
(emissão de títulos de dívida). Neste estudo, trataremos da primeira espécie de captação de recursos, mais especificamente aquela realizada por meio do bônus de subscrição.

O bônus de subscrição é um título negociável que confere ao seu titular o direito de subscrever ações da companhia em data futura, de acordo com preço de subscrição previamente estabelecido ou com base em critérios estipulados quando da emissão do título pela companhia. O exercício do bônus de subscrição se dá mediante a manifestação de vontade do titular nesse sentido e o pagamento do preço de subscrição de ações. Em contrapartida, a companhia deve emitir o número de ações correspondentes e registrá-las em nome do titular.

Instituto típico e exclusivo das sociedades anônimas de capital autorizado ${ }^{4}$, o bônus de subscrição é um instrumento autônomo com natureza jurídica de título de crédito ${ }^{5}$ e de valor mobiliário ${ }^{6}$. Por operar somente no âmbito da companhia de capital autorizado, o bônus de subscrição consiste em uma ferramenta ágil de captação de recursos pela sociedade, na medida em que no estatuto social da sociedade anônima de capital autorizado já há autorização para aumento de capital independentemente de reforma estatutária e, portanto, a operação prescinde de deliberação para aumento de capital, desde que o aumento se circunscreva ao limite estatutário estabelecido.

Assim, em virtude da referida agilidade para a realização de aumento de capital, a sociedade tem condições de melhor aproveitar uma conjuntura de mercado favorável, a qual pode não perdurar até consecução de todos os procedimentos necessários à concretização do aumento de capital se este fosse efetivado por meio de deliberação de assembléia geral. O regime do capital autorizado, portanto, permite que a companhia se capitalize por meio de deliberação do conselho de administração, se tal competência for a ele delegada ${ }^{7}$ pelo estatuto social.

\footnotetext{
${ }^{4}$ GUERREIRO, José Alexandre Tavares. Regime Jurídico do Capital Autorizado. São Paulo: Saraiva, 1984, p. 116.

${ }^{5}$ CINTRA, Maria Lúcia Borges de Araújo. Aspectos Jurídicos do Bônus de Subscrição. São Paulo, 1980, Dissertação (Mestrado em Direito Comercial), Faculdade de Direito, Universidade de São Paulo, p. 57.

6 TEIXEIRA, Egberto Lacerda; GUERREIRO, José Alexandre Tavares. Das Sociedades Anônimas no Direito Brasileiro, São Paulo: José Bushatsky Editor, 1979, p. 324.

${ }^{7}$ ERCKLENTZ, Enno. Modern German Corporation Law. New York: Oceana Publications, 1979, p. 384.
} 


\section{Estrutura}

Este estudo foi estruturado de modo a cobrir a análise tanto de aspectos intrínsecos como extrínsecos ao bônus de subscrição com o objetivo de formar um panorama abrangente e completo tanto do instituto estudado como das possíveis intersecções com outros institutos e também dos efeitos práticos decorrentes de sua prática.

Como ponto de partida, abordaremos, no primeiro capítulo, a origem do bônus de subscrição no direito norte-americano, sistema jurídico de onde surgiram as primeiras referências sobre a emissão, por companhias, de títulos que conferiam o direito de subscrição de ações e que, posteriormente, foram regulamentados pela legislação estadual de diversas unidades dos Estados Unidos da América.

Também nesse capítulo trataremos sobre a introdução de uma versão simplificada desse título no Brasil e como, em decorrência do desenvolvimento do mercado de capitais do país, o bônus de subscrição adquiriu, em 1976, a posição atual de instituto autônomo, sujeito a regras próprias e independentes de outros instrumentos que compõem a estrutura de financiamento das sociedades anônimas. Esse pequeno recuo histórico tem como objetivo lançar as bases sobre as quais se desdobrarão os capítulos subsequentes.

No segundo capítulo, desenvolvemos o exame da natureza jurídica do bônus de subscrição, a qual corresponde ao seu enquadramento como título de crédito e como valor mobiliário. Em virtude da classificação do bônus como título de crédito, foram abordadas questões decorrentes da aplicação do Código Civil de 2002 ao objeto de estudo, considerando que, diferentemente do anterior, esse diploma legal passou a tratar sobre a matéria atinente aos títulos de créditos, sendo pertinente tratar sobre a possibilidade de serem aplicadas as regras do Código Civil ao bônus de subscrição e, ainda, deste encampar a modalidade do título de crédito incompleto.

A parte seguinte do capítulo dedicamos à análise pormenorizada dos elementos subjetivos e objetivos e das características do bônus de subscrição. Nesse ponto descrevemos os fundamentos que permeiam o instituto, assim como os requisitos necessários para a sua emissão.

No terceiro capítulo, abordamos o exercício do bônus de subscrição, o qual envolve a decisão do titular de se tornar acionista da companhia emissora mediante o pagamento do preço de subscrição definido previamente. A companhia, por sua vez, deve emitir as ações e registrá-las em nome do titular ou determinar a sua escrituração pela instituição financeira contratada. Em virtude da possibilidade de descumprimento desta obrigação 
pela sociedade em detrimento do investidor, apresentamos a execução específica, regulada pelos artigos 461 e 644 do Código de Processo Civil, como a tutela jurisdicional adequada para remediar o inadimplemento da companhia.

Com o objetivo de aprimorar a caracterização do objeto de estudo, no quarto capítulo, realizamos um breve estudo comparativo deste e com outros instrumentos jurídicos que compartilham afinidades com o bônus de subscrição, quais sejam, a opção de compra outorgada a administradores, empregados e prestadores de serviços, a opção de compra negociada em bolsa e a debênture conversível em ação.

A escolha desses instrumentos para fins de comparação foi norteada pela capacidade que todos possuem de possibilitar seus titulares se tornarem acionistas de sociedade anônima. Além disso, a opção de compra de ações destinada a empregados e prestadores de serviços compartilha com o bônus de subscrição a restrição legal que apenas admite a sua emissão na vigência do regime de capital autorizado, bem como a raiz comum no direito norte-americano.

A confrontação proporcionada pela análise conjunta dos mencionados institutos, conforme entendemos, ajuda no processo de compreensão das características do bônus de subscrição e de eventuais pontos que deixam de ser confrontados quando os instrumentos jurídicos são analisados isoladamente.

O quinto capítulo dedicamos à pesquisa do uso do bônus de subscrição na prática societária do mercado de capitais. Ainda que não seja extensa a utilização do instituto, nessa parte final do trabalho, apresentamos o quadro atual e histórico de negociação do bônus de subscrição perante a BM\&FBOVESPA. Em seguida, analisamos os negócios jurídicos firmados no âmbito de companhias fechadas que, ao invés de objetivarem a capitalização da empresa, funcionam como sistemas de regulação da participação de acionistas e investidores ou para equilibrar posições acionárias de acordo com o cumprimento de metas de investimento ou com as mudanças decorrentes de operações de fusões e aquisições.

Por fim, analisamos a questão envolvendo a emissão de bônus de subscrição pela Companhia de Bebidas das Américas - AmBev que resultou em uma Consulta apresentada perante a Comissão de Valores Mobiliários (Processo CVM n SP2002/0474). A referida consulta oportunizou o debate acerca do bônus de subscrição e da interpretação dos critérios para determinação do preço de subscrição das ações decorrentes do seu exercício. Após o julgamento da controvérsia pela autarquia, a questão foi submetida ao Poder Judiciário e, atualmente encontra-se sub judice, em razão da pendência de julgamento do 
Recurso Especial interposto pela companhia perante a Quarta Turma do Superior Tribunal de Justiça (REsp n $1.348 .956 /$ RJ).

\section{Propósito}

Alguns anos após a edição da Lei das Sociedades Anônimas foram produzidos estudos $^{8}$ com o objetivo de traçar as características do bônus de subscrição e apresentar o instituto em sua versão autônoma. Estes trabalhos possuem grande relevância para a presente monografia, no entanto, em virtude do momento em que foram elaborados, não contemplam modificações provocadas por leis posteriores, nem puderam se aprofundar nos aspectos práticos do bônus de subscrição.

Desse modo, por meio deste estudo, buscamos realizar uma análise contemporânea do regime jurídico do bônus de subscrição em face da atual legislação e doutrina, expondo seus atributos e potencialidades como instrumento de captação de recursos para a sociedade de capital autorizado. Em virtude das mudanças ocorridas no ordenamento jurídico desde a implementação do título no direito brasileiro, procuramos adequar a sua sistemática às leis posteriores que restringiram sua emissão à forma nominativa e identificar eventuais relações com a regulamentação dos títulos de crédito pelo Código Civil de 2002.

Objetivamos também neste trabalho o exame da aplicação do instituto na prática societária, trazendo para a investigação dados relacionados à negociação do bônus de subscrição e informações sobre os desafios que esse título ocasiona para operadores do direito, companhias e investidores. Para tanto, utilizamos os subsídios disponibilizados pela BM\&FBOVESPA que possibilitaram verificar a relevância da negociação do título no mercado de capitais, realizamos estudo de caso sobre a emissão de bônus de subscrição pela Companhia de Bebidas das Américas - Ambev $^{9}$ e analisamos contratos societários envolvendo o foco deste trabalho. A pesquisa acerca da utilização desse título mostrou-se

\footnotetext{
${ }^{8}$ CINTRA, Maria Lúcia Borges de Araújo. Aspectos Jurídicos do Bônus de Subscrição. São Paulo, 1980, Dissertação (Mestrado em Direito Comercial), Faculdade de Direito, Universidade de São Paulo; GUERREIRO, José Alexandre Tavares. Regime Jurídico do Capital Autorizado. São Paulo: Saraiva, 1984; ARAGÃO, Paulo Cezar. Opções de Compra de Ações e Bônus de Subscrição. In: Revista dos Tribunais, v. 631, p. 63, maio, 1988; e KOHLER, Claudio. Bônus de Subscrição. In: Revista dos Tribunais. São Paulo, v. 641, março, 1989.

${ }^{9}$ Processo CVM no SP 2002/0474 e Apelação Cível nº 0047299-63.2003.8.19.0001 (TJRJ), em trâmite perante o Superior Tribunal de Justiça por força do REsp n ${ }^{\circ} 1.348 .956$.
} 
frutífera em oportunizar o questionamento de características importantes do bônus de subscrição e sua aplicabilidade frente às necessidades da prática, de modo a possibilitar o reconhecimento dos limites que devem atuar sobre o instituto. 


\section{CAPÍTULO 1 - A ORIGEM DO BÔNUS DE SUBSCRIÇÃO}

\section{Origem do instituto no direito norte-americano ${ }^{10}$}

Antes de tratar sobre o surgimento do bônus de subscrição nos Estados Unidos da América, é necessário tecer alguns comentários sobre a terminologia do instituto no direito norte-americano, tendo em visa as diferentes nomenclaturas dadas ao título, que, no direito brasileiro, possui denominação específica e típica: bônus de subscrição.

Fundado no case law ${ }^{11}$, o direito norte-americano possui maior flexibilidade terminológica, como é o caso do título em estudo que, na legislação dos EUA, é indicado como rights ${ }^{12}$, e, na doutrina, pode ser encontrado como stock option ou stock purchase warrant $^{13}$. Em linhas gerais, por meio destas diferentes expressões, o bônus de subscrição é apresentado como um direito de subscrição de ações negociável por meio do qual a companhia se compromete a entregar valores mobiliários mediante a apresentação de certificado e de pagamento de determinada quantia (consideration) antes ou na data estipulada para o exercício do título.

No direito norte-americano, o bônus de subscrição assume contornos maleáveis, na medida em que o stock purchase warrant pode incorporar o direito do seu titular subscrever ações, por prazo determinado ou indeterminado, onde o preço das ações a que o título dá direito é definido pelo conselho de administração ou pela maioria dos votos dos acionistas, quando não tiver valor nominal. A legislação norte-americana, nesse caso, não apresenta critérios para que se estabeleça o preço das ações, como ocorre no direito brasileiro $^{14}$.

\footnotetext{
${ }^{10}$ A proposta do presente capítulo é apresentar algumas notas históricas sobre o surgimento do bônus de subscrição, indicando as principais referências trazidas pela doutrina norte-americana acerca da origem do instituto. Assim, o objetivo consiste em fornecer informações sobre o contexto do nosso objeto de estudo e não um cotejamento histórico exaustivo do bônus de subscrição no direito norte-americano.

${ }^{11}$ Em termos simplificados, case law é o sistema jurídico que extrai princípios e regras jurídicas a partir de decisões judiciais derivadas de casos individuais, cf. West's Encyclopedia of American Law. 2. ed., Minneapolis: West Group Publishing, 1997.

${ }^{12}$ Cf. $\$ 157$ do Delaware Code.

${ }^{13}$ BOGEN, Jules I. Corporation Finance. New York: Alexander Hamilton Institute, 1958, p. 151: "Stock purchase warrants. Instead of making use of the conversion feature, corporations sometimes sell bonds or preferred stock with stock purchase warrants attached. These warrants permit the senior security holder to buy common shares for actual cash at stated prices while retaining the security he originally purchased. In other words, these warrants give security holder the privilege of investing in the enterprise additional capital for which he gets common stock".

${ }^{14}$ A fixação do preço de subscrição de ações no direito norte-americano não possui as restrições apresentadas na Lei de Sociedades Anônimas brasileira (art. 170, $\S 1^{\circ}$ ). De acordo com o disposto no Delaware Code,
} 
A doutrina brasileira, ao tratar sobre a origem norte-americana do bônus de subscrição, também utiliza esses termos, especialmente o stock option que, conforme já foi referido, é bastante ambíguo ${ }^{15}$, podendo tanto significar bônus de subscrição como opção de compra de ações destinada a administrador, empregado, ou prestador de serviço à companhia $^{16}$. Além disso, stock option pode significar a opção onerosa de comprar ou vender ações em determinado período com base em preço previamente estabelecido, seja ela negociada, ou não, na bolsa de valores.

Diante dessa terminologia múltipla e intercambiável, para diferenciar quando a doutrina e a lei norte-americanas utilizam a expressão stock option como bônus de subscrição ou como opção de compra, é necessário atentar para o elemento subjetivo do negócio jurídico, porquanto no caso do bônus de subscrição é a companhia quem emite o título que permite ao investidor titularizar ações. Porém, na opção de compra, a contratação é celebrada entre um acionista e um investidor, hipótese em que o direito de adquirir ações refere-se àquelas detidas pelo primeiro.

Em relação à opção de compra outorgada a administradores e empregados, a diferenciação também pode ser feita pelo elemento subjetivo, pois a outorga não se destina a investidores, mas às pessoas designadas na lei ("officers and employees of the corporation or of any of its subsidiaries" ${ }^{\prime 17}$ ). Assim, diante da pluralidade de nomenclaturas

quando as ações não tiverem valor nominal é suficiente que a determinação do preço seja definida pelo conselho de administração ou pelo voto da maioria dos acionistas com ações em circulação, nos termos do $\S 157$ (d) combinado com o $\$ 153$ (b): " $§ 153$ Consideration for stock.

(a) Shares of stock with par value may be issued for such consideration, having a value not less than the par value thereof, as determined from time to time by the board of directors, or by the stockholders if the certificate of incorporation so provides.

(b) Shares of stock without par value may be issued for such consideration as is determined from time to time by the board of directors, or by the stockholders if the certificate of incorporation so provides. (...)

15 Stock option também pode se referir às opções negociadas pelas bolsas de valores: "an exchange-traded stock option in the United States is an American-style option contract to buy or sell 100 shares of the stock. Details of the contract - the expiration date, the strike price, what happens when dividends are declared, how large a position investors can hold, and so on - are specified by the exchange" HULL, John C., Options, futures and other derivatives, 7. ed., Pearson Prentice Hall: Upper Saddle River (New Jersey), 2009, p. 185. No Brasil, essa acepção de stock option é tratada como "opções” ou também como "puts e call”, negócios oferecidos pela bolsa de valores, não se caracterizando por ser um títulos de emitido pela companhia, conforme CARVALHOSA, Modesto. Comentários à lei de sociedades anônimas, vol. 2, 5. Ed., São Paulo: Saraiva, 2011, p. 51.

${ }^{16}$ Cf. RADIN, Stephen A. The Business Judgement Rule: Fiduciary of Corporate Directors. vol. I, 6. ed., Wolters Kluwer Law \& Business/Aspen Publisher, 2009, p. 1039: "Stock options are a frequently used form of director and officer compensation". Vide também CINTRA, Maria Lúcia Borges de Araújo. Aspectos Jurídicos do Bônus de Subscrição, p. 54: "o bônus de subscrição e a opção de compra de ações, originaramse de um único instituto do direito norte americano: a stock option" CARVALHOSA, Modesto. Comentários à lei de sociedades anônimas, vol. 2, p. 59: "as stock options foram trazidas para o nosso direito por meio de dois diferentes institutos: a opção de compra, especialmente criada para atender aos interesses dos administradores, empregados e contratantes, com respeito às emissões de capital da companhia, e os bônus de subscrição (...)"

${ }^{17}$ Cf. $\$ 157$ do Delaware Code. 
e de significados, com o objetivo de reduzir a ambiguidade terminológica no presente estudo, utilizaremos preferencialmente a expressão stock purchase warrant para designar o bônus de subscrição.

De acordo com Carvalhosa, utilizando a denominação stock option, o bônus de subscrição é fruto da prática societária norte-americana que posteriormente passou a ser reconhecida pelas legislações estaduais dos EUA, especialmente nos estados de Delaware e de New York ${ }^{18}$. Porém, antes de ser positivado, o título é encontrado na doutrina norteamericana quando esta trata de bonds with detachable or non-detachable stock purchase warrant $^{19}$. Nessa época (final do século XIX) o bônus de subscrição era utilizado de modo ocasional, especialmente em reorganizações financeiras ${ }^{20}$.

O stock purchase warrant consistia em uma vantagem adicional agregada à obrigação (bond) com a função de aumentar a atratividade do instrumento financeiro ao permitir que seu titular subscrevesse ações de emissão da companhia devedora.

A partir de 1920, bonds with stock purchase warrant passam a ser utilizadas como meio de financiamento normal, mas ainda nessa época eram anexados apenas a convertible bonds. As convertible bonds, por sua vez, são obrigações que podem ser convertidas em ações ou mesmo em obrigações emitidas em outras condições. A conversão em ações tem por objetivo permitir que o titular, a sua escolha, permaneça como credor ou torne-se acionista.

Em 1924, as sociedades passam a emitir non convertible bonds com stock purchase warrant ou simplesmente stock warrant, cuja vantagem consistia em incorporar o direito de subscrever ações a determinadas condições e prazo. A subscrição de ações ocorria em numerário e não tinha por efeito extinguir o crédito do titular, contrariamente ao que ocorre na hipótese de convertible bonds ${ }^{21}$.

\footnotetext{
${ }^{18}$ CARVALHOSA, Modesto. Comentários à lei de sociedades anônimas, vol. 2, p. 51.

${ }^{19}$ Com a finalidade de evitar que o investidor deprima a cotação de valores mobiliários aos quais são atribuídos bônus de subscrição, a prática norte-americana desenvolveu os non-detachable stock purchase warrants, os quais não permitem que o investidor venda os valores mobiliários e permaneça apenas com o bônus de subscrição, cf. BOGEN, Jules I. Corporation Finance, p. 155. A lei brasileira é omissa sobre a possibilidade de bônus de subscrição não destacáveis em relação às ações ou debêntures aos quais foram atribuídos. Parece-nos, desse modo, que é possível a aplicação do modelo ao direito pátrio, considerando a ausência de proibição legal e o fato de que tal prática, fundamentalmente, não viola outras disposições e princípios que regem a matéria, e que a atribuição do bônus de subscrição não isenta o investidor do pagamento do preço de subscrição das ações.

${ }_{20}$ ROSSET, Paul René. Les Titres Américains, R. Pichon \& Durand-Auzias: Paris, 1931, p. 126: "Les obligations avec warrant de souscription, de même que les obligations convertibles, ont leur origine aux États-Unis d'Amérique; elles sont cepedent beaucoup plus récentes que celles-ci. Si elles ont étés employée depuis longtemps à titre occasionnel, lors de réorganization financières, ce n'est que dans 1920, sauf erreur, qu'on reccours à elles comme moyen de financement normal; (...)".

${ }^{21}$ ROSSET, Paul René. Les Titres Américains, pp. 127-129.
} 
Posteriormente, em virtude da necessidade de financiamento de grandes empreendimentos em serviços essenciais e ferrovias, o stock purchase warrant evoluiu e se tornou um instrumento autônomo, distanciando-se de bonds, debêntures e ações preferenciais com rendimentos fixos e limitados para uma posição mais próxima aos securities com mais possibilidade especulativa.

O stock purchase warrant, portanto, passou a ser emitido independentemente de outros valores mobiliários ou como um direito destacável ou não destacável. Na última hipótese, para que fosse possível exercer o direito de subscrever ações, era necessário apresentar, juntamente com o stock warrant, também o valor mobiliário ao qual este estava atrelado $^{22}$. Essa mudança ocorreu durante o período pós Primeira Guerra Mundial, em que os investidores passaram a se interessar mais por ações ordinárias em virtude do cenário econômico então vigente que combinava inflação da moeda americana, elevação do preço de ações ordinárias e aumento do preço de commodities, todos esses fatores intensificados pelos lucros dos tempos de guerra ${ }^{23}$.

Segundo estudo conduzido por Clifford Charles Keith, no período de 8 meses (de 01 de junho de 1928 a 31 de janeiro de 1929), 45\% dos títulos anunciados na seção financeira do The New York Times nos EUA por sociedades do setor industrial e de public utility eram acompanhados por stock purchase warrants e/ou permitiam a conversão em ações, indicando um volume expressivo de utilização do instituto ${ }^{24}$. Esses títulos ofereciam como vantagem aos investidores a combinação das qualidades protetivas dos bonds contra flutuações de curto prazo do mercado, bem como a oportunidade de, no longo prazo, auferir ganhos de capital por meio da titularização de ações ordinárias.

De acordo com o uso da época, a doutrina definia o bônus de subscrição como " $a$ corporate instrument by whose provisions the corporation binds itself to deliver shares profits stock to the holder at his election upon payment to it by the holder of a specified sum of money per share, at or within a time, on conditions set forth in the instrument" ${ }^{25}$.

\footnotetext{
${ }^{22}$ CARY, William L.; EISENBERG, Melvin Aron. Cases and Materials on Corporations, 5. Ed., Mineola: Foundation Press, 1980, p. 1146: "stock warrants may be issued in conjunction with a senior security in lieu of a conversion feature, or the may sold alone for cash. They are contract rights to buy a stated number of shares of a security (typically common stock) at a stated price for a stated period. If issued with another security they may be detachable (and thus sold independently) or non- detachable"

${ }_{23}$ GARNER, Russel D., FORSYTHE, Alfred S., Stock Purchase Warrants and Rights. In: Southern California Law Review, vol. 4, 1930-1931, p. 269 - 270

${ }^{24}$ KEITH, Clifford Charles. Convertible Securities and Stock Purchase Warrants. In: Rocky Mountain Law Review, vol. 2, 1929-1930, p. 17.

${ }^{25}$ BERLE JUNIOR., Adolf Augustus. Studies in the Law of Corporation Finance, Chicago: Callaghan, 1928, p. 131.
} 
O Delaware Statute, de 1929, que positivou o stock purchase warrant, simplesmente permitia a sua emissão. A superficialidade da legislação, além se ser um traço do sistema jurídico de common law, tem relação com a forma que as sociedades eram reguladas no final do século XIX. Até 1875, à parte de raras exceções, nos EUA, predominava o sistema de constituição de sociedades por meio de atos legislativos especiais (special act of the legislature). Esse método levou a abusos e escândalos que culminaram na modificação da Constituição de diversos estados norte-americanos a fim de que as sociedades pudessem ser criadas apenas mediante sujeição a leis gerais ${ }^{26}$.

$\mathrm{O}$ estado norte-americano de New Jersey adotou o que é considerado o primeiro estatuto liberal de sociedades, pouco tempo depois o estado de Delaware replicou diversos dispositivos para criar o seu próprio estatuto. Em 1915 o estatuto de Delaware já era considerado moderno e liberal. Em virtude deste conjunto normativo, mais favorável às empresas, Delaware é o estado mais procurado para registro de sociedades ${ }^{27}$.

Assim, os stock purchase warrants foram incorporados ao direito americano pela Delaware Corporation $\mathrm{Law}^{28}$ que atualmente integra o Delaware Code, um corpo de leis do estado de Delaware que trata de temas abrangentes como agricultura, transporte, educação, eleições e até o objeto do nosso estudo, encontrado no Título 8 (Corporations), onde são estabelecidas as regras para sociedades. Mais especificamente, o $§ 157^{29}$ dispõe

${ }^{26}$ CARY, William L. Cases and Materials on Corporations, 4 ed., Mineola: The Foundation Press, 1969, p. 9: "shall not be created by special act, except for municipal purposes, and in cases where, in the judgement of the Legislature the objects of the corporation cannot be attained under general laws".

27 Além de ser um dos ordenamentos jurídicos pioneiros em acolher as necessidades das companhias em termos de regulamentação societária, o Estado de Delaware é ainda o estado norte-americano líder na escolha como sede das companhias por oferecer cortes judiciais com larga experiência e credibilidade no julgamento de questões societárias, cf. MUNHOZ, Eduardo Secchi. A importância do sistema de solução de conflitos para o direito societário: limites do instituto da arbitragem. In: YARSHELL, Flávio Luiz; PEREIRA, Guilherme Setoguti J. Processo Societário, São Paulo: Quartier Latin, 2012, p. 83.

28 MARTINS, Fran. Comentários à Lei das Sociedades Anônimas. 4 ed., rev. e atual., Rio de Janeiro: Forense, 2010, p. 286.

${ }^{29} \S 157$. Rights and options respecting stock.

(a) Subject to any provisions in the certificate of incorporation, every corporation may create and issue, whether or not in connection with the issue and sale of any shares of stock or other securities of the corporation, rights or options entitling the holders thereof to acquire from the corporation any shares of its capital stock of any class or classes, such rights or options to be evidenced by or in such instrument or instruments as shall be approved by the board of directors.

(b) The terms upon which, including the time or times which may be limited or unlimited in duration, at or within which, and the consideration (including a formula by which such consideration may be determined) for which any such shares may be acquired from the corporation upon the exercise of any such right or option, shall be such as shall be stated in the certificate of incorporation, or in a resolution adopted by the board of directors providing for the creation and issue of such rights or options, and, in every case, shall be set forth or incorporated by reference in the instrument or instruments evidencing such rights or options. In the absence of actual fraud in the transaction, the judgment of the directors as to the consideration for the issuance of such rights or options and the sufficiency thereof shall be conclusive.

(c) The board of directors may, by a resolution adopted by the board, authorize 1 or more officers of the corporation to do 1 or both of the following: (i) designate officers and employees of the corporation or of any 
sobre a possibilidade de uma companhia emitir direitos ou opções que garantam ao seu titular a possibilidade de adquirir da companhia ações, conforme instrumento aprovado pelo conselho de administração.

De acordo com o $\$ 157$, esses “direitos ou opções” (rights or options) emitidos pela companhia podem ter prazo limitado ou ilimitado ${ }^{30}$, devendo constar o preço das ações (ou a fórmula para determiná-lo) no certificado ou resolução do conselho de administração que estabelecer a criação e emissão destes direitos ou opções. Exceto no caso de fraude, a decisão dos membros do conselho de administração relativa ao preço de emissão dos direitos ou opções será definitiva. O bônus de subscrição pode ser emitido por companhias abertas e fechadas, porém são as primeiras que mais comumente encontram utilidade para o instituto ${ }^{31}$.

No subitem (c) do referido dispositivo, a lei autoriza que os direitos ou opções podem ou não ser concedidos a administradores ou empregados. Isso significa que o $§ 157$ do Delaware Code constitui também fundamento jurídico para o instituto da opção de compra de ações, o qual também será objeto de análise no Capítulo 4.

Berle e Means, em A Sociedade Moderna e a Propriedade Privada, criticavam a previsão do instituto no Delaware Corporation Law na medida em que este admitia a criação de stock purchase warrant sem a necessidade dos títulos serem registrados publicamente e com base em condições discricionariamente definidas por conselheiros da sociedade, em número ilimitado e a qualquer tempo. Os autores identificaram nessa flexibilidade para emissão de bônus de subscrição o enfraquecimento da posição dos antigos acionistas em decorrência da diluição experimentada pela subscrição de novas ações, as quais conferem aos novos acionistas parcela do aumento de valor da companhia mediante o pagamento das ações fixado em montante inferior ${ }^{32}$.

of its subsidiaries to be recipients of such rights or options created by the corporation, and (ii) determine the number of such rights or options to be received by such officers and employees; provided, however, that the resolution so authorizing such officer or officers shall specify the total number of rights or options such officer or officers may so award. The board of directors may not authorize an officer to designate himself or herself as a recipient of any such rights or options.

(d) In case the shares of stock of the corporation to be issued upon the exercise of such rights or options shall be shares having a par value, the consideration so to be received therefore shall have a value not less than the par value thereof. In case the shares of stock so to be issued shall be shares of stock without par value, the consideration therefor shall be determined in the manner provided in $\$ 153$ of this title.

${ }^{30}$ FOLK, III, Ernest L., The Delaware General Corporation Law: a commentary and analysis. Boston: Little, Brown, 1972, p. 128.

${ }^{31}$ ISRAELS, Carlos L. Corporate Practice, 3 ed., revisado por Alan M. Hoffman, New York: Practising Law Institute, 1974, p. 35.

32 BERLE JUNIOR., Adolf Augustus; MEANS, Gardiner Coit. The Modern Corporation and Private Propriety. New York: Macmillan, 1940, p. 151: "These instruments have not been subject to legal scrutiny. 
Com a finalidade de construir um corpo jurídico mais uniforme das leis societárias, que no direito norte-americano é de competência do legislativo estadual ${ }^{33}$, em 1950 foi editado o Model Business Corporation Act pela American Bar Association, instituição que corresponde no Brasil à Ordem dos Advogados do Brasil. No Model Business Corporation Act, o bônus de subscrição é regulado pelo $\$ 6.24^{34}$ que segue basicamente os contornos do Delaware Code, onde a redação abrange tanto esse título como a opção de compra destinada a administradores e empregados.

Atualmente, a doutrina norte-americana define o stock purchase warrant como valor mobiliário que permite o titular adquirir, do emissor, antes do término do prazo estabelecido, ações com base em preço fixado em dinheiro. A desvantagem é que o bônus de subscrição exige uma perspectiva de valorização da companhia para que o titular possa exercer o bônus ${ }^{35}$.

\section{O começo do instituto no Brasil}

No Brasil, a origem do bônus de subscrição está relacionada com a previsão do cupão destacável ${ }^{36}$ que incorporava o direito de subscrever ações, nos termos do art. 44,

Under the Delaware law, they need not be made matters of public record, their terms are at the discretion of the Directors, their number is unlimited; and they may be issued at any time. (...)".

33 E. NORMAN VEASEY, On Corporate Codification: A Historical Peek At The Model Business Corporation Act And The American Law Institute Principles Through The Delaware Lens, disponível em http://www.law.duke.edu/journals/lcp.

${ }^{34} \S 6.24$ Share Options

(a) A corporation may issue rights, options, or warrants for the purchase of shares or other securities of the corporation. The board of directors shall determine (i) the terms upon which the rights, options, or warrants are issued and (ii) the terms, including the consideration for which the shares or other securities are to be issued. The authorization by the board of directors for the corporation to issue such rights, options, or warrants constitutes authorization of the issuance of the shares or other securities for which the rights, options or warrants are exercisable.

(b) The terms and conditions of such rights, options or warrants, including those outstanding on the effective date of this section, may include, without limitation, restrictions or conditions that:

(1) preclude or limit the exercise, transfer or receipt of such rights, options or warrants by any person or persons owning or offering to acquire a specified number or percentage of the outstanding shares or other securities of the corporation or by any transferee or transferees of any such person or persons, or

(2) invalidate or void such rights, options or warrants held by any such person or persons or any such transferee or transferees.

${ }^{35}$ JOHNSON JUNIOR., Charles J.; MCLAUGHLIN, Joseph. Corporate Finance and the Securities Laws. $3^{\mathrm{a}}$ ed. New York: Aspen Publishers, 2004, p. 897.

${ }^{36}$ CARVAlHOSA, Modesto. Comentários à lei de sociedades anônimas, vol. 2, p. 47: "Era o cupão um título de crédito destacável, originário das debêntures conversíveis em ações, negociável de forma autônoma. Consequentemente, a transferência desse título outorgava ao seu possuidor direito autônomo de subscrever ações da companhia. Ao proceder à transmissão do direito contido no cupão, o titular da debênture perdia o direito adicional de subscrever ações. O sistema funcionava, portanto, de modo semelhante ao conhecimento de depósito e respectivo warrant. O titular da debênture conversível somente poderia subscrever ação se 
$\S 8^{\circ 37}$ da Lei $n^{\circ} 4.728$, de 1965 . Essa lei tinha como função regulamentar o mercado de capitais após a reforma bancária ocorrida em $1964^{38}$ que culminou com a criação do Banco Central do Brasil por meio da Lei ${ }^{\circ} 4.595$.

$\mathrm{O}$ artigo 44 da Lei $\mathrm{n}^{\circ} 4.728$ estabelecia que as sociedades anônimas poderiam emitir debêntures ou obrigações que possibilitavam a sua conversão em posição acionária. Com base no parágrafo $8^{\circ}$ do mesmo dispositivo legal, era facultada a emissão de um instrumento denominado cupão destacável que admitia a negociação em separado desse direito de subscrever ações. Alternativamente, o direito de subscrição podia ser transferido mediante averbação no próprio título ou no livro de registro da companhia.

É interessante notar que as características do cupão destacável são similares aos dos bonds with detachable stock purchase warrant, a versão anterior não integralmente autônoma do stock purchase warrant que, na prática norte-americana, também conferia ao seu titular a possibilidade de negociar o direito de converter-se em acionista da sociedade emissora das obrigações adquiridas.

Posteriormente, a Lei das Sociedades Anônimas (Lei no 6.404/1976) conferiu autonomia ao bônus de subscrição ao deixar de tratá-lo simplesmente como cupão destacável das debêntures conversíveis em ação. O instituto passou a ser regulado pelos artigos 75 a 79 com a denominação específica de bônus de subscrição ${ }^{39}$.

De acordo com a Exposição de Motivos da Lei $n^{\circ}$ 6.404/76, a introdução desse novo instituto tinha como objetivo oferecer às companhias mais uma forma de "mobilização de recursos em certas conjunturas do mercado" e, dentro deste escopo, fornecer um instrumento financeiro que auxilie na colocação de valores mobiliários. Esse é o caso quando o bônus de subscrição é atribuído à subscrição de debêntures e ações como vantagem especial (art. 77).

Diferentemente da versão precursora, o bônus de subscrição foi designado como instituto privativo das sociedades anônimas de capital autorizado. Na modelagem atual, o

exibisse, juntamente com o título, o cupão. Se não o fizesse, pressupunha-se que o direito autônomo representado pelo cupão havia sido negociado".

${ }^{37}$ Lei ${ }^{\circ}$ 4.728/65: Art. 44. As sociedades anônimas poderão emitir debêntures ou obrigações, assegurando aos respectivos titulares o direito de convertê-las em ações do capital da sociedade emissora. (...)

$\$ 8^{\circ} \mathrm{O}$ direito à subscrição de capital poderá ser negociado ou transferido separadamente da debênture conversível em ação, desde que seja objeto de cupão destacável ou sua transferência seja averbada pela sociedade emissora, no próprio título e no livro de registro, se for o caso.

${ }^{38}$ SOUZA JUNIOR, Francisco Satiro de. Regime Jurídico das Opções Negociadas em Bolsas de Valores, São Paulo, 2002. Tese (Doutorado em Direito Comercial), Faculdade de Direito, Universidade de São Paulo, p. 69.

${ }^{39} \mathrm{O}$ direito francês adotou a mesma nomenclatura: "bons de souscription autonome", cf. HOVASSE, Henri. Les Augmentations de Capital a Souscription Conditionelle. Paris: Economica, 1988, p. 105. 
título pode ser alienado ou atribuído pela companhia e confere ao seu titular o direito de subscrever ações mediante o pagamento do preço do exercício.

A vantagem do bônus de subscrição, conforme será aprofundado no próximo capítulo, é o fato deste permitir que a sociedade emissora prefixe um preço para as ações que serão futuramente subscritas, tendo o titular do instrumento, se decidir exercer o direito, a obrigação de pagar apenas o preço estabelecido anteriormente e não o preço em que as ações estejam sendo negociadas nesse momento posterior ${ }^{40}$.

Aqui, diferentemente do direito norte-americano, a tipificação do bônus de subscrição na lei acionária afasta a possibilidade de confusão terminológica com outros instrumentos financeiros das sociedades anônimas.

Desde a sua introdução no sistema jurídico pátrio, o bônus de subscrição tem apresentado uma importância pequena como instrumento de captação de recursos às sociedades anônimas. Em dezembro de 2014, apenas cinco companhias tiveram bônus de subscrição admitidos à negociação na BM\&FBOVESPA ${ }^{41}$. Não obstante, conforme será tratado no Capítulo 5, a prática societária desenvolveu usos alternativos para esse título, que são emitidos privadamente por companhias fechadas como instrumento de organização da participação acionária ou como forma de equilibrar a posição de acionista e investidores em operações de fusões e aquisições.

\footnotetext{
${ }^{40}$ MARTINS, Fran. Comentários à Lei das Sociedades Anônimas, p. 286.

${ }^{41}$ Em 09/12/2014, estavam admitidos à negociação na BM\&FBOVESPA bônus de subscrição relativos à BR Pharma (BPHA11), Indusval (IDVL11), Iochpe-Maxion (MYPK11), Kepler Weber (KEPL11) e Tectoy (TOYB13).
} 


\section{CAPÍTULO 2 - CARACTERIZAÇÃO E NATUREZA JURÍDICA DO BÔNUS DE SUBSCRIÇÃO}

\section{Natureza jurídica}

Neste capítulo abordaremos os elementos constitutivos do bônus de subscrição e suas principais características. Para possibilitar esse estudo, iniciaremos com a investigação sobre a natureza jurídica do instituto, a qual deverá nortear a sua posterior caracterização e determinar o sistema de normas aplicáveis ao título.

De acordo com a doutrina brasileira, o bônus de subscrição possui uma dupla natureza jurídica: de título de crédito e de valor mobiliário. Por essa razão, ambas as qualificações serão abordadas, dada a sua relevância para traçar o perfil do bônus de subscrição.

\subsection{O bônus de subscrição como valor mobiliário}

No sistema jurídico brasileiro, a primeira inserção da expressão valores mobiliários ocorreu na Lei $\mathrm{n}^{\circ}$ 4.728/65. A categoria dos valores mobiliários era composta inicialmente por uma lista de instrumentos financeiros que mais tarde passaram a sujeitar-se às normas da Lei $\mathrm{n}^{\circ} 6.385 / 76$, a qual trata fundamentalmente da regulação do mercado de valores mobiliários e da instituição da Comissão de Valores Mobiliários.

A lei de 1976 inicialmente enumera diversos instrumentos no art. $2^{\circ}$ e afasta de seu alcance normativo as exceções listadas no $§ 1^{\circ}$ do mencionado dispositivo. Em 2001, com a edição da Lei $n^{\circ} 10.303$, com nítida inspiração no direito norte-americano no que tange ao tratamento dos securities, foi ampliada a abrangência dos instrumentos considerados como valores mobiliários para incluir, no rol do art. $2^{\circ}$, o inciso IX, de modo que nessa categoria passam a fazer parte "quaisquer outros títulos ou contratos de investimento coletivo, que gerem direito de participação, de parceria ou de remuneração, inclusive resultante de prestação de serviços, cujos rendimentos advêm do esforço do empreendedor ou de terceiros" quando ofertados publicamente. 
O objetivo dessa alteração legislativa foi dar maior flexibilidade à matéria e permitir que a lei abarcasse, também, contratos com derivativos e commodities ${ }^{42}$. A partir de então, considera-se que o rol do art. $2^{\circ}$ passou a ser meramente exemplificativo com a possibilidade de englobar outros instrumentos financeiros não nominalmente indicados.

Quanto ao enquadramento do bônus de subscrição como valor mobiliário, a resposta é simples, pois está expresso de forma direta no inciso I do artigo $2^{\circ}$ da pela Lei $\mathrm{n}^{\circ}$ 6.385/76:

"Art. 2 São valores mobiliários sujeitos ao regime desta Lei:

I - as ações, debêntures e bônus de subscrição;"

A designação na lei, entretanto, não é suficiente para extrair um conceito de valor mobiliário e, com isso, estabelecer os parâmetros que regem essa categoria. A identificação do instituto nesse universo indica que o bônus de subscrição está entre os instrumentos submetidos à regulação das normas atinentes aos valores mobiliários e à fiscalização exercida pela Comissão de Valores Mobiliários, no âmbito de sua competência. A definição sobre os valores mobiliários tampouco é encontrada na lei que disciplina o mercado de capitais e que regulamenta o Conselho Monetário Nacional e o Banco Central $\left(\right.$ Lei $\left.\mathrm{n}^{\circ} 4.728 / 65\right)$.

$\mathrm{Na}$ sua redação original, o inciso II do art. $2^{\circ}$ da Lei $\mathrm{n}^{\circ} 6.385 / 76$ conferia ao Conselho Monetário Nacional a possibilidade de atribuir tal natureza jurídica a outros títulos. Essa discricionariedade dada ao Conselho Monetário Nacional foi removida da referida norma por meio da Lei $\mathrm{n}^{\circ} 10.303$, de 2001, que deu nova redação ao artigo e ampliou a competência regulatória da Comissão de Valores Mobiliários para alcançar derivativos, contratos futuros, opções, entre outros, formando um sistema típico, porém aberto.

Tal alteração foi importante, porém não suficiente para uma conceituação dos valores mobiliários, cuja importância reside na necessidade de se firmar as bases de uma rede de proteção a investidores, companhias e acionistas, conferindo maior eficiência ao

\footnotetext{
${ }^{42}$ EIZIRIK, Nelson L. GAAL, Ariádna B., PARENTE, Flávia, HENRIQUES, Marcus de Freitas. Mercado de Capitais: Regime Jurídico. 3 ed., rev. e ampl., Rio de Janeiro: Renovar, 2011, p. 56.
} 
mercado de capitais e oferecendo maior segurança jurídica por meio da regulação das operações envolvendo os valores mobiliários ${ }^{43}$.

Assim, para uma melhor compreensão sobre o que significa essa categoria jurídica, é necessário recorrer à doutrina. Segundo Mattos Filho, valores mobiliários são títulos que incorporam investimentos oferecidos ao público, sobre os quais o investidor não tem controle direto e cuja contribuição pode ocorrer em dinheiro, bens ou serviços, na expectativa de lucro, não sendo necessária a emissão do título para a materialização da relação obrigacional, seja em nível associativo, a título de empréstimos ou como aplicação especulativa ${ }^{44}$.

A partir desta definição é possível identificar a função do valor mobiliário, cuja emissão e negociação permitem às sociedades acessarem a poupança popular ${ }^{45}$ como fonte de obtenção de recursos e financiamento. Diante disso, e dos exemplos que a Lei $\mathrm{n}^{\circ}$ 6.385/76 fornece, temos que as principais características dos valores mobiliários são (i) não possuírem valor intrínseco, na medida em que dependem de fatores externos ao instrumento como, por exemplo, liquidez e lucratividade; (ii) serem emitidos e ofertados aos investidores para negociação no mercado secundário por número indeterminado de vezes, isto é, não servem para consumo ou uso; (iii) terem aptidão de circular e natureza fungível, diferindo, porém, quanto ao direito que atribuem a seus titulares e às diferentes finalidades a que visam atender ${ }^{46}$.

Em que pese não haver dúvida acerca da classificação do bônus de subscrição como valor mobiliário em virtude da tipificação legal, as características apresentadas para essa classificação afastam a noção de que, na hipótese do bônus de subscrição ser emitido por companhia fechada, este perderia a sua natureza de valor mobiliário. Isso porque a capacidade de negociá-lo publicamente depende apenas do registro da companhia como

\footnotetext{
${ }^{43}$ SOUZA JUNIOR, Francisco Satiro de. Regime Jurídico das Opções Negociadas em Bolsas de Valores, p. 65.

${ }^{44}$ MATTOS FILHO, Ary Oswaldo de. O Conceito de Valor Mobiliário. In: Revista de Administração de Empresas, Rio de Janeiro: Fundação Getúlio Vargas, n. 25, abr./jun, p. 47. Em outras palavras, "o valor mobiliário é materializado por um título que é o suporte do direito. O título nominativo comprova a inscrição no registro de transferência, que faz presumir a propriedade do titular com força probante absoluta. (...) Em sua nova acepção, a palavra título designa um valor escritural sem individualidade”, cf. EIZIRIK, Nelson. A Lei das S/A Comentada, vol. I, p. 122. Para Carlos Osório de Castro, a propósito da conceituação no direito português, "valor mobiliário é o direito ou a posição enquanto incorporada num título ou representada por uma inscrição em conta - é aquela substância sob esta particular forma" e que possui especial aptidão para a circulação através de negócios. A sua fungibilidade permite a negociação no mercado de capitais. CASTRO, Carlos Osório de. Valores Mobiliários: Conceitos e Espécies. 2. ed., Porto: Universidade Católica Portuguesa, 1998, p. 11-12.

${ }^{45}$ EIZIRIK, Nelson. A Lei das S/A comentada, vol. I, p. 53.

${ }^{46}$ EIZIRIK, Nelson. GAAL, Ariádna B., PARENTE, Flávia, HENRIQUES, Marcus de Freitas. Mercado de Capitais: Regime Jurídico. 3 ed., rev. e ampl., Rio de Janeiro: Renovar, 2011, p. 25-26.
} 
sociedade aberta perante a Comissão de Valores Mobiliários e do registro de oferta pública do título perante a mesma autarquia. Ou seja, não há alteração de seus elementos constitutivos.

Logo, a distribuição pública de valores mobiliários não confere a natureza jurídica aos títulos negociados, mas serve como critério para determinar, nos termos do art. $4^{\circ}$ da Lei $\mathrm{n}^{\circ}$ 6.404/1976, se a companhia é fechada ou aberta e a sua sujeição às regras da Comissão de Valores Mobiliários.

Assim, ainda que emitido por companhia fechada, o bônus de subscrição continua a ostentar a posição de valor mobiliário, considerando que o instituto se identifica com os elementos caracterizadores dessa categoria citados pela doutrina, atendendo à função de financiar a sociedade emissora sob a forma de instrumento negociável sujeito ao risco do investimento que permite ao titular tornar-se acionista mediante pagamento do preço estabelecido.

\subsection{O bônus de subscrição como título de crédito}

Os títulos de crédito atendem a uma necessidade histórica de permitir a circulação de riquezas com maior eficiência, propiciando o desenvolvimento econômico da sociedade em geral. É um instrumento importante tanto no contexto do renascimento europeu como no atual mundo globalizado dada a sua aptidão de promover o progresso econômico, a ampliação das possibilidades de integração de recursos e o destino de investimentos.

Conforme ensina Tullio Ascarelli ${ }^{47}$, o direito brasileiro adotou a teoria da criação em relação aos títulos de crédito. Isso significa dizer que o fundamento da obrigação cambiária é criação do título, de modo que é admitido que o título tenha entrado em circulação até mesmo contra a vontade do emitente, como se verifica do disposto no art. 905, parágrafo único, do Código Civil brasileiro ${ }^{48}$.

A relação jurídica criada pelo título de crédito entre credor e devedor é de natureza contratual, de modo que, nesse âmbito, são as admitidas defesas pessoais asseguradas pelo

\footnotetext{
${ }^{47}$ ASCARELLI, Tullio. Teoria Geral dos Títulos de Crédito, Campinas: Servanda, 2009, pp. 425-426 e 431: "A declaração cambiária é perfeita com a simples criação do título. Que ele saia das mãos do devedor é uma conditio juris para a eficácia da obrigação, mas o negócio é perfeito desde a criação do título e, portanto, a exceção de falta de emissão não pode ser oposta validamente ao terceiro possuidor de boa-fé".

${ }^{48}$ Código Civil, Art. 905. O possuidor de título ao portador tem direito à prestação nele indicada, mediante a sua simples apresentação ao devedor.

Parágrafo único. A prestação é devida ainda que o título tenha entrado em circulação contra a vontade do emitente.
} 
direito e as garantias contra vícios de origem. O mesmo não ocorre em relação ao terceiro com o qual foi negociado o título, cuja relação jurídica com o devedor tem caráter de declaração unilateral manifestada pelo devedor no sentido de obrigar-se ao portador do título $^{49}$.

Em relação ao bônus de subscrição, a lei não o define como título de crédito, porém a doutrina é contundente acerca da sujeição do instrumento à teoria dos títulos de crédito ${ }^{50}$. Não obstante a assertiva doutrinária, a investigação científica exige a demonstração, de modo que, nesse ponto, os esforços serão concentrados em verificar o atendimento do bônus de subscrição aos requisitos dos títulos de crédito.

Os títulos de crédito são caracterizados como documento (suporte físico ou não) necessário para exercitar um direito literal e autônomo no qual é mencionado ${ }^{51}$. Essa definição foi adotada pelo Código Civil de 2002, em seu art. 887 (“O título de crédito, documento necessário ao exercício do direito literal e autônomo nele contido, somente produz efeito quando preencha os requisitos da lei”). Partindo deste conceito legal, para melhor apreender as implicações da natureza dos títulos de crédito, é preciso que nos detenhamos rapidamente sobre cada um de seus elementos essenciais, que integram a norma legal: autonomia, literalidade e cartularidade.

\subsubsection{Autonomia}

A autonomia deve ser entendida em relação ao propósito do título de crédito, o qual permite a transferência segura e eficaz dos direitos que nele estão inseridos ${ }^{52}$. Isso significa

\footnotetext{
${ }^{49}$ RIZZARDO, Arnaldo. Títulos de Crédito. Rio de Janeiro: Forense, 2006, p. 83.

${ }^{50}$ GUERREIRO, José Alexandre Tavares. Regime Jurídico do Capital Autorizado, p. 122. No mesmo sentido, BULGARELLI, Waldirio. Títulos de Crédito, 11. ed., São Paulo: Atlas, 1995, p. 102; CINTRA, Maria Lúcia Borges de Araújo. Aspectos Jurídicos do Bônus de Subscrição, p. 90, EIZIRIK, Nelson L. GAAL, Ariádna B., PARENTE, Flávia, HENRIQUES, Marcus de Freitas. Mercado de Capitais: Regime Jurídico, p. 80: "o bônus de subscrição representa, inequivocadamente, um direito de crédito de seu titular, consistente no direito de exigir a prestação do devedor, nele especificada. (...) Embora seja caracterizado como título de legitimação, na medida em que legitima seu proprietário a tornar-se acionista da companhia, a doutrina é unânime em afirmar que o bônus de subscrição possui natureza jurídica de título de crédito".

${ }^{51}$ VIVANTE, Cesare. Trattato di diritto commerciale. vol. III, Milano: Casa Editrice Dottor Francesco Vallardi. Milão, 1924, p. 123: "Il titolo di credito à un documento necessario per esercitareil diritto letterale e autonomo che vi à menzionato". Em sentido contrário: COMPARATO, Fábio Konder. Novos Ensaios e Pareceres de Direito Empresarial. Rio de Janeiro: Forense, 1981, p. 17 "o título de crédito é, sempre, um documento e esse seu indefectível substrato material determina um regime jurídico muito especial, notadamente em matéria da posse ou de literalidade das obrigações nele mencionadas (o chamado "direito cartular')".

${ }^{52}$ PESSOA, Ana Paula Gordilho. Breves reflexões sobre os títulos de crédito no novo código civil. In: PENTEADO, Mauro Rodrigues (coord.), Títulos de Crédito, São Paulo: Walmar, 2004, p. 39.
} 
que outras questões atinentes ao negócio jurídico originário não aderem ao título. Dito de outro modo, após a transferência do título, seu titular passa a ter direito autônomo que não depende da relação anterior criada entre devedor e credor original, de modo que exceções atinentes a essa relação não podem ser atribuídas aos cessionários de boa-fé ${ }^{53}$.

A autonomia é mencionada na redação do art. 887 do Código Civil, que inaugura a parte destinada aos títulos de crédito no referido diploma legal e tem como função oferecer segurança ao cessionário e, desse modo, incentivar a circulação do título e os direitos por ele incorporados.

Identifica-se o elemento da autonomia no bônus de subscrição na medida em que o direito de subscrever ações, contido no título, é independente do negócio jurídico que lhe deu causa. A autonomia, portanto, significa que a irregularidade verificada em relação a uma obrigação contida no título não afetará a eficácia das demais obrigações ${ }^{54}$. A autonomia em relação às obrigações também se aplica à autonomia da titularidade, de modo que as transferências anteriores são irrelevantes para o exercício do direito que encerra.

Nesse sentido, a propriedade do bônus de subscrição denota uma aquisição a título originário que independe das relações entre a companhia emissora e os anteriores detentores do título, pondo a salvo o adquirente de boa-fé em relação aos titulares anteriores $^{55}$.

\subsubsection{Literalidade}

Etimologicamente a literalidade está associada à ideia de "letra", objeto comumente associado ao papel. Entretanto, essa vinculação da palavra não significa que os títulos de crédito devem ser expressos em papel. Em lingüística, segundo ensina Newton de Lucca, a literalidade "significa a capacidade do signo de ser tomado em si mesmo e não como referência a outra coisa" ${ }^{n 6}$. Assim, a literalidade indica que o direito representado pelo título está limitado ao conteúdo e sua extensão indicados no suporte que o sustenta. Este como se analisará no tópico atinente à cartularidade - poderá ser informatizado. A noção

\footnotetext{
${ }^{53}$ BULGARELLI, Waldirio. Títulos de Crédito, p. 59.

${ }^{54}$ RIZZARDO, Arnaldo. Títulos de Crédito, p. 14.

${ }^{55}$ EIZIRIK, Nelson. A Lei das S/A comentada, vol. I, p. 458

${ }^{56}$ DE LUCCA, Newton. Aspectos da teoria geral dos títulos de crédito. São Paulo: Livraria Pioneira, 1979, p. 48.
} 
de confinar o direito pertinente à literalidade do instrumento serve para proteger os direitos do titular legitimado, de modo que a preocupação do credor deve restringir-se à segurança que o documento, emitido mediante caracteres de computador, é capaz de guardar ${ }^{57}$.

A literalidade, portanto, informa que o título compreende o conteúdo, a extensão e as modalidades do direito nele encerrado de modo decisivo e, com isso, desempenha a função constitutiva em relação à declaração cartular ${ }^{58}$. Ou seja, está presente a literalidade do título quando os seus termos abrangem de modo completo as regras pelas quais credor e devedor estão obrigados e a falta de outros critérios não comprometem a mobilização do crédito, uma de suas principais finalidades.

A característica da literalidade, no contexto do bônus de subscrição, delimita a obrigação da companhia em subscrever novas ações no prazo e no preço estipulados, garantindo ao adquirente do título esses mesmos direitos no mercado secundário. São irrelevantes, portanto, as causas que geraram a emissão do bônus de subscrição.

Desse modo, relativamente ao bônus de subscrição, a literalidade se verifica na medida em que as "condições de exercício do direito devem estar expressamente fixados no título ou na deliberação do órgão componente (assembleia geral ou conselho de administração) que aprovou a sua emissão (art. 79),"59.

\subsubsection{Cartularidade}

Historicamente, o requisito da cartularidade estava vinculado à necessidade do título de crédito ser instrumentalizado em papel. Porém, a evolução tecnológica que teve lugar há diversas décadas implicou no avanço e no desenvolvimento da teoria dos títulos de crédito para além do suporte físico. A doutrina e a lei, suplantando esse paradigma, já repeliram qualquer limitação do título ao meio em papel, podendo seu suporte se constituir de qualquer coisa que dê a conhecer um fato ${ }^{60}$, admitindo o meio eletrônico como instrumento a propiciar a circulação de riquezas e de conhecimento ${ }^{61}$.

\footnotetext{
${ }^{57}$ PESSOA, Ana Paula Gordilho. Breves reflexões sobre os títulos de crédito no novo código civil, p. 39.

${ }^{58}$ ASCARELLI, Tullio, Teoria geral dos títulos de crédito, p. 49

${ }^{59}$ EIZIRIK, Nelson. A Lei das S/A comentada, vol. I, p. 459.

${ }^{60}$ PESSOA, Ana Paula Gordilho. Breves reflexões sobre os títulos de crédito no novo código civil, p. 40.

${ }^{61}$ Em sentido contrário, Luis Felipe Spinelli argumenta que "a disciplina dos títulos de créditos pressupõe a existência física do documento. Ademais, a cártula, justamente documento palpável, é algo único, sem viabilidade de reprodução, o que dá a segurança que se precisa para a circulação/mobilização do crédito (garantindo-se, assim, a autonomia das obrigações e a literalidade da declaração cambial, o que conduz à
} 
A cartularidade, assim, decorre dos elementos anteriores da autonomia e da literalidade e corresponde à necessidade de exibição do título para exercer os direitos nele contido, conforme se denota da redação do $\S 3^{\circ 62}$ do art. 889 do Código Civil. O dispositivo legal demonstra que paradigma do papel foi substituído por tecnologia capaz de permitir a identificação da origem do documento e do seu emissor, a fim de garantir a segurança indispensável à transferência de dados e à atividade negocial ${ }^{63}$.

Especificamente em relação ao bônus de subscrição, a característica da cartularidade pode ser identificada com a previsão legal de emissão de certificado ou com a prática corrente que utiliza o sistema de registro ou escrituração. No que se refere ao certificado do bônus de subscrição, o art. $79^{64}$ explicita os elementos que lhe são fundamentais, porém, não o exige como instrumento essencial para a emissão do título ou para exercício dos direitos nele incorporados. Em realidade, a emissão de certificado é facultativa, motivo pelo qual a falta de tal formalidade em nada afeta a cartularidade do bônus de subscrição.

Essa posição é confirmada pela mudança da Lei das Sociedades Anônimas que restringiu a emissão de bônus de subscrição à modalidade nominativa. Inicialmente a Lei $n^{\circ}$ 6.404/1976 admitia a emissão de ações endossáveis e ao portador, porém, em 1990, foi publicada a Lei n ${ }^{\circ} 8.021$ que alterou a redação do art. 20 da Lei de Sociedades Anônimas, estabelecendo a emissão exclusiva de ações nominativas. Posteriormente, em 1997, foi promulgada a Lei $n^{\circ} 9.457$ que adequou as demais disposições da lei acionária à anterior vedação legal que impossibilitou as sociedades de emitirem ações nominativas. Com isso, a forma nominativa também passou a ser obrigatória para o bônus de subscrição.

Em decorrência da referida mudança, de forma ainda mais contundente, passou a ser irrelevante a emissão de certificado do bônus de subscrição, tendo em vista que a

inoponibilidade das exceções)", cf. SPINELLI, Luis Felipe. Os títulos de crédito eletrônicos e as suas problemáticas nos planos teórico e prático. In: Revista do Ministério Público do Rio Grande do Sul, Porto Alegre, n. 67, set./dez., 2010, p. 133.

${ }^{62}$ Código Civil, Art. 889 (...) $\$ 3^{\circ}$ O título poderá ser emitido a partir dos caracteres criados em computador ou meio técnico equivalente e que constem da escrituração do emitente, observados os requisitos mínimos previstos neste artigo.

${ }^{63}$ PESSOA, Ana Paula Gordilho. Breves reflexões sobre os títulos de crédito no novo código civil, p. 42.

${ }^{64}$ Art. 79. O certificado de bônus de subscrição conterá as seguintes declarações:

I - as previstas nos números I a IV do artigo 24;

II - a denominação "Bônus de Subscrição";

III - o número de ordem;

IV - o número, a espécie e a classe das ações que poderão ser subscritas, o preço de emissão ou os critérios para sua determinação;

$V$ - a época em que o direito de subscrição poderá ser exercido e a data do término do prazo para esse exercício;

$V I$ - o nome do titular;

VII - a data da emissão do certificado e as assinaturas de dois diretores. 
transferência de títulos nominativos se opera por meio de sistema de registro ou escrituração $^{65}$. O registro se dá pela inscrição em livro específico, enquanto a forma escritural é aquela em que o lançamento do título é feito por instituição depositária dos livros da sociedade (art. 100, $\S 2^{\circ}$ ).

Assim, sendo possível outras formas de representação que permitem a circulação do direito encerrado pelo título com a segurança capaz de impedir que mais de uma pessoa se declare proprietária do mesmo título, não é exigível que o bônus de subscrição tenha como suporte físico o papel. Nesse ponto, as modalidades registrária e escritural atendem ao objetivo essencial da cartularidade nos títulos de crédito, pois conferem segurança e certeza à circulação dos direitos por eles representados ${ }^{66}$.

\subsubsection{Classificação dos títulos de crédito}

De acordo com o direito que incorporam, os títulos de crédito podem ser classificados em (i) títulos de crédito próprios ou stricto sensu, (ii) títulos de participação e (iii) títulos que conferem direito de propriedade. Isto é, os títulos de créditos não são apenas aqueles que "conferem direito de crédito", essa categoria jurídica abrange todo o gênero de títulos que desempenham a função de corporificar direitos.

O título de crédito próprio ou em sentido estrito é aquele que encerra uma operação de crédito (letras de câmbio, notas promissórias, cheques, títulos da dívida pública, debênture). Por essa qualidade, estão fortemente vinculados ao elemento pessoal do emissor, pois é com base na confiança em relação ao pagamento que haverá a circulação com maior ou menor facilidade. O título de participação, como o próprio nome denota, confere ao seu titular o direito de participação, como é o caso das ações em relação à sociedade que as emitiu.

O título de crédito que contempla direitos de propriedade (conhecimento de transporte, depósito em armazéns gerais), não confere um crédito propriamente dito ao titular, mas o legitima em relação à propriedade da coisa a que se refere. Esse é o caso do bônus de subscrição, o qual legitima o seu titular a contratar a subscrição de ações da sociedade emissora $^{67}$. Não obstante as singularidades que distinguem cada espécie acima

\footnotetext{
${ }^{65}$ CARVALHOSA, Modesto. Comentários à lei de sociedades anônimas, vol. II, p. 65.

${ }^{66}$ EIZIRIK, Nelson. A Lei das S/A comentada, vol. I, p. 457.

67 CARVAlHOSA, Modesto. Comentários à Lei das Sociedades Anônimas, vol. II, p. 61. Em sentido contrário, segundo Maria Lúcia Cintra, o bônus de subscrição se caracteriza por ser "um título que confere a
} 
descrita, elas reúnem elementos comuns (autonomia, literalidade e cartularidade), os quais são os requisitos que garantem a esse conjunto a natureza de título de crédito.

Desse modo, considerando as características apresentadas (autonomia, literalidade e cartularidade) e as diferentes espécies que permeiam a classe dos títulos de crédito, é possível concluir que o bônus de subscrição possui natureza jurídica de título de crédito, pois, ainda que não esteja relacionado a uma operação de crédito pecuniário propriamente dita, ele legitima o seu titular ao direito de subscrever ações que circula segundo regime próprio $^{68}$.

A reforçar a qualidade de título de crédito do bônus de subscrição devemos mencionar a possibilidade deste instrumento ser objeto de penhor, caução, usufruto, fideicomisso, alienação fiduciária em garantia, cláusula de inalienabilidade e incomunicabilidade, por força do que dispõe o art. 78, parágrafo único. Este dispositivo determina a aplicação das seções V a VII do capítulo III da Lei de Sociedades Anônimas, dentre as quais está incluída a seção que regulamenta a "constituição de direito reais e outros ônus" (artigos 39 e 40).

Do mesmo modo em que é determinada a propriedade do bônus de subscrição, os gravames que incidirem sobre o bônus de subscrição deverão ser averbados nos livros correspondentes, sejam eles da companhia emissora ou da instituição depositária, conforme a modalidade escritural ou registraria do bônus de subscrição.

\subsection{A dupla natureza jurídica do bônus de subscrição}

Da simplificada síntese que apresentamos acima em relação aos valores mobiliários e aos títulos de crédito, é possível concluir que ambas as naturezas jurídicas permeiam o bônus de subscrição. Seja como título de crédito ou como valor mobiliário, são encontrados no bônus de subscrição todos os requisitos indispensáveis indicados pela doutrina e pela lei para o seu enquadramento nestas classificações, de modo que o bônus de subscrição deve ser entendido sob sua perspectiva de título negociável em massa que confere o direito a uma determinada participação acionária.

seu titular o direito a uma prestação consubstanciada em uma obrigação de fazer, qual seja, a de aumentar o capital e emitir ações para possibilitar a conclusão de um contrato de subscrição". Segundo entende, não confere, desse modo, direito de disposição sobre coisa ou representativo de mercadoria, tampouco atribui direito de participação nem direito a um crédito pecuniário stricto sensu como meio de representar quantia em dinheiro, cf. CINTRA, Maria Lucia Borges de Araújo. Aspectos jurídicos dos bônus de subscrição, p. 60.

${ }^{68}$ EIZIRIK, Nelson. A Lei das S/A comentada, vol. I, p. 124. 
Para Bulgarelli, é possível a coexistência da natureza de título de crédito e de valor mobiliário em um mesmo instrumento, porque essas duas categorias jurídicas possuem liame lógico ${ }^{69}$, considerando as diferentes referências ${ }^{70}$ encontradas ao longo da Lei $\mathrm{n}^{\circ}$ 6.404/76 relativamente à teoria dos títulos de crédito, ao mesmo tempo em que esta regulamenta diversos valores mobiliários, especialmente o bônus de subscrição.

Assim, enquanto título de crédito, o bônus de subscrição se reveste dos elementos essenciais a esta categoria jurídica promovendo a incorporação do direito de subscrever ações em um documento (físico ou não) e capaz de gerar obrigações e permitir a circulação desse direito. Na qualidade de mobiliário, insere-se em uma classe de títulos negociados em massa. E, ao desempenhar este papel, incide sobre ele todo um arcabouço jurídico destinado a proteger investidores, companhias e acionistas.

\subsection{Aplicabilidade das disposições do Código Civil ao bônus de subscrição}

O Código Civil de 2002 inclui, em seu Título VIII ("Dos Títulos de Crédito"), regras gerais aplicáveis aos títulos de crédito. Assim, considerando a definição do bônus de subscrição como título de crédito, é possível questionar a respeito da aplicabilidade das disposições do diploma civil ao instituto.

Analisando as normas que passaram a fazer parte do código de 2002 que não possuem correspondência no código de 1916, percebe-se um avanço de unificação do que é chamado pela dogmática de direito civil e comercial em uma única lei abrangendo as matérias de título de crédito e de sociedades. A despeito disso, em ambos os casos, foi expressamente respeitado o âmbito de aplicação das leis específicas, na medida em que há um dispositivo indicando expressamente a supletividade do Código Civil no tocante às sociedades anônimas (art. 1.089 ${ }^{71}$ ) e aos títulos de crédito (art. 903).

No caso dos títulos de crédito, o intuito da codificação foi o de criar uma disciplina geral cuja aplicação fosse meramente supletiva e, diante da eventual falta de regras

\footnotetext{
${ }^{69}$ BULGARELLI, Waldirio. Títulos de Crédito, p. 99 e, na p. 102, acrescenta que os valores mobiliário "são títulos de massa, títulos negociáveis e títulos societários. Participam e devem integrar-se à teoria dos títulos de crédito, não só para que se mantenha a unidade conceitual e sistemática, mas também porque estão impregnados, senão de todo, ao menos, de vários requisitos característico dos títulos de crédito".

${ }^{70}$ Como, por exemplo, quando os valores mobiliários são tratados na lei das sociedades anônimas como títulos (artigos 46, 55, 75, 101, etc, assim como na Lei $\mathrm{n}^{\circ}$ 6.385/76), transferíveis por endosso (antes da reforma realizada pela Lei $\mathrm{n}^{\circ}$ 8.021/1990 que os limitou à forma nominativa), passíveis de serem gravados por usufruto, alienação fiduciária (art. 40) ou funcionarem com garantia, caução e penhor (art. 39).

${ }^{71}$ Código Civil, Art. 1.089. A sociedade anônima rege-se por lei especial, aplicando-se-lhe, nos casos omissos, as disposições deste Código.
} 
especiais na legislação específica, permitir a emissão de títulos de crédito atípicos (art. 887 e 889 do Código Civil) com circulação assegurada pelas disposições estipuladas pelas regras gerais ${ }^{72}$, e afastada a legislação geral quando esta contrariar a lei cambiária ${ }^{73}$.

Assim, o bônus de subscrição, dada a sua natureza de título de crédito, se sujeita às normas do Código Civil, porém estas são absolutamente limitadas pelas regras específicas (lei das sociedades anônimas e leis que regulamentam os mercados de capitais e os valores mobiliários). O mesmo ocorre com a sociedade anônima, único tipo social habilitado à emissão de bônus de subscrição (desde que sob o regime de capital autorizado), para o qual o Código Civil não fornece regras gerais, reservando-se a função supletiva para os casos omissos na lei específica.

Como título de crédito, o bônus de subscrição encontra nas regras do Código Civil normas aplicáveis como, por exemplo, os artigos 358 e 893. Segundo este último, a transferência do título implica também a de todos os direitos que lhe são inerentes. Em outros dispositivos que tratam dos títulos de crédito, o Código Civil é explícito no sentido de respeitar suas particularidades, como o art. 896 que refere sobre a reivindicação de portador de boa-fé com a pertinente ressalva: "na conformidade das normas que disciplinam a sua circulação".

Assim, se o bônus de subscrição não pode ser emitido ao portador, fica claro que a regra do art. 896 do Código Civil não é aplicável à espécie. E, ainda que não houvesse ressalva no texto legal, pela própria natureza dos títulos de crédito - os quais possuem regras específicas em legislação esparsa - a lei geral não poderia se sobrepor ao direito cambiário $^{74}$. Consequentemente, com base nas características do bônus de subscrição que serão abordadas abaixo, é incompatível com o instituto o art. 890 do Código Civil que considera como não escrita a cláusula de juros, por exemplo. O objetivo desta norma é estipular que o valor incorporado no título seja determinado e retirar qualquer incerteza sobre a importância devida ${ }^{75}$. No caso do bônus de subscrição o preço de subscrição das ações pode ser indeterminado, já que, de acordo com o art. 79, V da Lei 6.404/76, não há

\footnotetext{
72 ADAMEK, Marcelo Vieira von. Títulos de crédito incompletos (títulos típicos e atípicos). O art. 891. In: PENTEADO, Mauro Rodrigues (coord.), Títulos de Crédito, São Paulo: Walmar, 2004, p. 267.

73 PESSOA, Ana Paula Gordilho. Breves reflexões sobre os títulos de crédito no novo código civil, pp. 47-48.

${ }^{74}$ BULGARELLI, Waldirio. Títulos de Crédito, p. 54: “os títulos de crédito são constitutivos de um direito distinto da sua causa, e por isso, as normas que os regem, chamadas em seu conjunto de direito cambial ou cambiário, são específicas e, em alguns casos constituem até mesmo derrogações do direito comum."

${ }^{75}$ RIZZARDO, Arnaldo. Títulos de Crédito, p. 75: "A cláusula que prevê juros, importando em não se admitir sua inclusão nos títulos de crédito. Conterão eles valores certos, de modo a afastar qualquer dúvida sobre o montante devido, que já deverá estar inserido na cártula".
} 
exigência para que conste um valor fixo, devendo apenas conter os critérios capazes de determinar o preço das ações.

Assim, a lei de sociedades anônimas, por sua especialidade ao tratar do bônus de subscrição, afasta a aplicação de regras do mencionado art. 890, não podendo se cogitar sobre a inviabilidade do preço contido no título prever a incidência de juros. A corroborar com nosso entendimento, vale citar os artigos $48^{76}$ e $49^{77}$ do Decreto $n^{\circ}$ 57.663/66 que admitem a aplicação de juros para a letra de câmbio.

Em virtude dessa função subsidiária do Código Civil, questões como a limitação de juros imposta pelo art. 406, vinculada ao direito das obrigações, são inaplicáveis ao bônus de subscrição, na medida em que corresponde a instituto amparado por regras próprias que levam em conta a sua estrutura e funcionamento, incompatíveis com a mencionada restrição. Pela mesma razão não se pode cogitar da aplicabilidade do disposto no art. $591^{78}$ do Código Civil, que se refere ao contrato de mútuo e, desse modo, constitui matéria estranha ao bônus de subscrição.

Quanto à regra que possibilita a transferência de título nominativo por endosso (art. 923 do Código Civil), esta também não é aplicável ao bônus de subscrição, pois a transmissão da propriedade deve ser feita, necessariamente, de acordo com o disposto nas Seções V a VII do Capítulo III da Lei de Sociedades Anônimas que tratam sobre certificados, propriedade, circulação, constituição de direitos reais e outros ônus sobre as ações (art. 78, parágrafo único). Ou seja, a emissão de bônus de subscrição deve ser registrada no Livro de Registro de Bônus de Subscrição ou por meio de escrituração realizada por agente emissor (art. 101).

\subsection{Os títulos de crédito incompletos}

Considerando a natureza jurídica de título de crédito do bônus de subscrição e o fato de serem admitidos pela legislação, pela doutrina e pela prática os títulos de crédito incompletos, é pertinente perquirir sobre a possibilidade da emissão do bônus de

\footnotetext{
${ }^{76}$ Decreto $\mathrm{n}^{\circ}$ 57.663/66, Art. 48. O portador pode reclamar daquele contra quem exerce o seu direito de ação:

$1^{\circ}$. O pagamento da letra não aceita não paga, com juros se assim foi estipulado;

$2^{\circ}$. Os juros à taxa de 6 por cento desde a data do vencimento; (...)

${ }^{77}$ Decreto ${ }^{\circ} 57.663 / 66$, Art. 49. A pessoa que pagou uma letra pode reclamar dos seus garantes:

$1^{\circ}$. A soma integral que pagou;

$2^{\circ}$. Os juros da dita soma, calculados à taxa de 6 por cento, desde a data em que pagou; (...)

78 Código Civil, Art. 591. Destinando-se o mútuo a fins econômicos, presumem-se devidos juros, os quais, sob pena de redução, não poderão exceder a taxa a que se refere o art. 406, permitida a capitalização anual.
} 
subscrição sem parte de seus elementos típicos, isto é, incompleto, considerando as particularidades societárias que cercam o instituto.

Para tanto, começaremos a tratar da noção do que caracteriza um título de crédito completo. Segundo Marcelo von Adamek, o título de crédito completo pode ser compreendido como "aquele que, no momento de sua emissão, reúne todos os requisitos essenciais e supletivos ditados pela respectiva lei de regência"79. Em sentido oposto, título de crédito incompleto é aquele emitido sem reunir todos os seus requisitos. Porém, esse critério ainda não deixa claro quais são os requisitos dispensáveis e quais são os essenciais à existência de um título de crédito, ainda que incompleto.

No âmbito dos títulos de crédito incompletos, a doutrina os divide entre títulos de crédito incompletos (stricto sensu) e título em branco, cuja diferença repousa na presença, no caso do segundo, de um acordo de preenchimento do título ${ }^{80}$. Todavia, por ser este um critério subjetivo de difícil aferição, não pode ser levado em conta para a finalidade da investigação que ora se busca. Assim, são títulos de crédito incompletos aqueles emitidos sem todos os requisitos de sua espécie, porém que reúnem os requisitos mínimos elementares da fattispecie cambiária: a assinatura cambiariamente utilizável e instrumento com cláusula cambiária ${ }^{81}$.

Nesse caso, o título de crédito incompleto já é título de credito, porém ineficaz. Faltando-lhe os requisitos mínimos do título, “o negócio jurídico não deixa de existir, permanecendo válido e assegurando o exercício dos direitos que dele emanam" 82 . Logo, não produz os efeitos típicos dos títulos de crédito, mas poderá servir para desencadear efeitos probatórios.

Havendo título de crédito incompleto, considera-se que o seu portador possui mandato implícito para completar o documento com base no acordo existente entre este e o emitente. $^{83}$ Logo, ainda que faltantes determinadas informações necessárias à

\footnotetext{
${ }^{79}$ ADAMEK, Marcelo Vieira von. Títulos de crédito incompletos (títulos típicos e atípicos). O art. 891, p. 271.

${ }^{80}$ ADAMEK, Marcelo Vieira von. Títulos de crédito incompletos (títulos típicos e atípicos). O art. 891, p. 272: "No título em branco, o signatário intencionalmente omite, para que seja posteriormente preenchido, um ou mais requisitos; e, para suprir essas omissões voluntárias, existe um acordo regulando a forma de preenchimento. O título em branco, portanto, seria um título de formação sucessiva, colocado em circulação pela vontade do próprio signatário. Por outro lado, no título incompleto em sentido estrito, faltam um ou mais requisitos e, para suprir essas omissões, não há regras ou parâmetros definidos pelo signatário, pois o título, assim incompleto, foi colocado em circulação sem ou contra a sua vontade, de forma intempestiva".

${ }^{81}$ ADAMEK, Marcelo Vieira von. Títulos de crédito incompletos (títulos típicos e atípicos). O art. 891, p. 275.

${ }^{82}$ RIZZARDO, Arnaldo. Títulos de Crédito, p. 127.

${ }^{83}$ LUCCA, Newton de. Comentários ao novo código civil, vol. XII, Rio de Janeiro: Forense, 2003, p. 169170: "Entende-se, portanto - no âmbito da teoria geral dos documentos -, que o portador de um título de
} 
operacionalização do instrumento financeiro, este gera obrigações cambiárias para o subscritor frente a terceiro de boa-fé, tendo em vista a possibilidade de completá-los com base no que as partes acertaram antecipadamente.

A partir da descrição acerca dos títulos de crédito incompletos e do seu funcionamento, cabe verificar se tal modalidade é aplicável ao bônus de subscrição. Para tanto, é necessário recorrer às regras que regem o bônus de subscrição e analisar se estas também oferecem a mesma flexibilidade admitida em relação aos títulos de crédito em geral.

De acordo com a lei acionária, a criação do bônus de subscrição depende de deliberação pelo órgão societário competente, conforme determinar o estatuto social da companhia emissora. Observando-se apenas este primeiro requisitos para a emissão de bônus de subscrição, já se nota a enorme diferença em relação à exigência para emissão desse título. Enquanto outros títulos de crédito exigem tão somente a capacidade civil, a lei acionária requer o preenchimento de diversos preceitos para que o elemento subjetivo de emissão do bônus seja atendido. Isso se deve em decorrência do objeto das normas que regem o bônus de subscrição, as quais visam proteger não apenas relações jurídicas entre credor, devedor e terceiros, mas todo o universo relacionado às sociedades e ao mercado de capitais, onde os títulos negociados implicam não apenas direitos, deveres e obrigações, mas também encadeamentos sistêmicos que impactam tanto os participantes do mercado, como aqueles que não atuam diretamente nele.

Por esse motivo, não é possível, por exemplo, a emissão de bônus de subscrição sem a determinação do preço de subscrição de ações de modo que este pudesse ser "preenchido" pelo investidor, ainda que todas as demais exigências para a emissão do bônus de subscrição tivessem sido atendidas. Isso porque a competência para definir esse critério, conforme a lei acionária, é exclusiva dos órgãos da companhia autorizados pelo estatuto social, não podendo ser conferida a terceiro. A explicação para tal limitação decorre dos efeitos que o preço das ações de uma companhia produz sobre direitos patrimoniais e políticos dos acionistas, no âmbito interno da sociedade. E, tratando-se de companhia aberta, o preço das ações pode ter repercussão sobre outros ativos, tanto da sociedade emissora como de outras companhias participantes do mercado.

crédito em branco recebeu mandato implícito para preenchê-lo de conformidade com os ajustes celebrados entre ele e o signatário do título. Se houver eventual abuso de preenchimento, sempre haverá a possibilidade de oposição do signatário e o tomador imediato, mas militará em favor deste último a presunção de veracidade das cláusulas lançadas no título.” 
Assim, não é possível aplicar a noção de título de crédito incompleto aos bônus de subscrição, porquanto os requisitos elementares a esse tipo ("instrumento com cláusula cambiária" e "assinatura cambiariamente utilizável”) são insuficientes para que o título seja considerado um bônus de subscrição e possa gerar efeitos como tal.

Além disso, o bônus de subscrição necessita de providências de caráter formal que não possuem correspondência nos títulos de crédito em geral como, por exemplo, a exigência de registro ou escrituração, usualmente dispensável aos títulos de crédito. É o que nos alerta Carvalhosa, para quem "o direito de subscrição não existe sem o título registrado, custodiado ou lançado (artigos 34, 41 e 100 - bônus nominativos ou escriturais); o direito de subscrição não pode ser exigido sem o registro ou lançamento dos bônus à companhia, para que esta o satisfaça" ${ }^{~}{ }^{4}$. Isto é, para a válida existência do bônus de subscrição, não basta a emissão com os elementos mínimos como é admitido aos títulos de crédito incompletos.

A confirmar nosso entendimento, vale citar que, ao longo de toda a lei acionária inúmeras são as referências que exigem a presença de todos os seus requisitos para que a propriedade dos valores mobiliários produza efeitos perante terceiros (competência dos órgãos societários, quorum de aprovação de deliberações, aprovação de assembleia de avaliação para constituição da companhia), incluindo o competente registro ou escrituração $^{85}$, de modo que a sistemática admitida para a circulação e produção de efeitos dos títulos de crédito incompletos não é aplicável ao bônus de subscrição.

A impossibilidade da emissão de bônus de subscrição incompleto também está relacionada com a sua natureza de valor mobiliário, considerando que título em questão corresponde a uma categoria que se destina à circulação em massa e que, portanto, tem potencial para atingir não apenas as partes envolvidas no negócio jurídico, mas outros participantes do mercado não diretamente relacionado à emissão em tela. Assim, é pertinente que as regras incidentes sobre o bônus de subscrição sejam mais rígidas que aquelas referentes aos títulos de crédito, as quais admitem a sua circulação sob a modalidade incompleta.

Logo, diante das particularidades que envolvem a emissão do bônus de subscrição, não é possível considerá-lo emitido quando faltarem seus requisitos essenciais, tais como a deliberação do órgão competente determinando a sua emissão, o prazo para o seu exercício, o preço de emissão (ou a especificação de que o título será atribuído

\footnotetext{
${ }^{84}$ CARVALHOSA, Modesto. Comentários à lei de sociedades anônimas, vol. II, p. 63.

${ }^{85}$ A título exemplificativo, vide artigos $31,35,58, \S 5^{\circ}, 142, \S 1^{\circ}$ da Lei $n^{\circ} 6.404 / 76$.
} 
gratuitamente), o preço de subscrição das novas ações ou os critérios para determiná-lo, a quantificação e a qualificação das ações a serem subscritas.

Por outro lado, os elementos do certificado do bônus de subscrição, referidos no inciso I do art. 79 que remete ao art. 24 , I a $\mathrm{IV}^{86}$, não são indispensáveis à emissão do bônus de subscrição. A omissão de informações sobre "sede e prazo de duração" da companhia, "valor do capital social, a data do ato que o tiver fixado" ou "o limite da autorização, em número de ações ou valor do capital social", no nosso entender, não prejudica o reconhecimento do bônus de subscrição e dos direitos que este incorpora.

Isso não significa que essas informações não tem relevância na emissão do título. Certamente, haverá maior nível de transparência e segurança jurídica caso todos esses dados sejam fornecidos ao investidor em bônus de subscrição. Contudo, para a finalidade de traçar um paralelo com os títulos de crédito incompletos e identificar os elementos mínimos e indispensáveis para a emissão de bônus de subscrição, entendemos que são suficientes (i) a deliberação da assembleia geral ou do conselho de administração de sociedade anônima sob o regime de capital autorizado determinado a sua emissão e fixando (ii) o preço de emissão ou se serão atribuídos gratuitamente, (iii) o prazo para o seu exercício, (iv) o preço de subscrição das novas ações ou os critérios para determiná-lo e (v) a quantificação e a qualificação das ações a serem subscritas.

Ademais, cabe ressaltar que a lei de sociedades anônimas não prevê a hipótese de complementação do bônus de subscrição na falta de seus requisitos como ocorre com nota promissória, em relação à qual há determinação legal indicando como sanar omissões. Em conformidade com o art. $76^{87}$ da Lei Uniforme de Genebra, internalizado no direito pátrio pelo Decreto $n^{\circ} 57.663 / 66$, se não for determinado o prazo de pagamento, considera-se que

\footnotetext{
${ }^{86}$ Art. 24. Os certificados das ações serão escritos em vernáculo e conterão as seguintes declarações: I - denominação da companhia, sua sede e prazo de duração;

II - o valor do capital social, a data do ato que o tiver fixado, o número de ações em que se divide e o valor nominal das ações, ou a declaração de que não têm valor nominal;

III - nas companhias com capital autorizado, o limite da autorização, em número de ações ou valor do capital social;

IV - o número de ações ordinárias e preferenciais das diversas classes, se houver, as vantagens ou preferências conferidas a cada classe e as limitações ou restrições a que as ações estiverem sujeitas;

${ }^{87}$ Decreto $\mathrm{n}^{\circ}$ 57.663/66, Art. 76 - O título em que faltar algum dos requisitos indicados no artigo anterior não produzirá efeito como nota promissória, salvo nos casos determinados das alíneas seguintes.

A nota promissória em que não se indique a época do pagamento será considerada pagável à vista.

$\mathrm{Na}$ falta de indicação especial, lugar onde o título foi passado considera-se como sendo o lugar do pagamento e, ao mesmo tempo, o lugar do domicílio do subscritor da nota promissória.

A nota promissória que não contenha indicação do lugar onde foi passada considera-se como tendo-o sido no lugar designado ao lado do nome do subscritor.
} 
a nota promissória foi emitida à vista. A mesma lógica é encontrada no art. $10^{88}$ da Lei Uniforme, a qual admite a possibilidade de letra incompleta e define os limites de sua eficácia.

\section{Características do bônus de subscrição}

Identificada a dupla natureza jurídica do bônus de subscrição, enquanto título de crédito e valor mobiliário, é possível passar ao exame das características desse instrumento jurídico. Iniciaremos descrevendo as partes que compõe as relações jurídicas suscitadas desde a emissão até a sua negociação, identificando os órgãos e instituições que de alguma forma participam ou tem competência para atuar em matéria de bônus de subscrição.

Em seguida, analisaremos a composição do bônus de subscrição (objeto e finalidade), as relações jurídicas e os institutos implicados na sua emissão (direito de preferência, diluição injustificada), assim como elementos facultativos que comumente fazem parte do título.

\subsection{Elementos subjetivos}

De acordo com os artigos 75 e 76 da Lei de Sociedades Anônimas, o bônus de subscrição pode ser emitido pela assembleia geral ou pelo conselho de administração da companhia sob o regime de capital autorizado.

Compõem a relação jurídica que envolve a emissão e o exercício do bônus de subscrição, de um lado, a companhia emissora, por meio de seus órgãos e, de outro, os investidores em bônus de subscrição. Os acionistas da companhia emissora poderão participar na relação se decidirem exercer o direito de preferência quando da emissão do bônus de subscrição. Caberá ao conselho fiscal da companhia fiscalizar a proposta de emissão e à Comissão de Valores Mobiliários supervisionar a distribuição pública desses valores mobiliários, caso realizada por companhia aberta.

\footnotetext{
${ }^{88}$ Decreto $^{\circ}$ 57.663/66, Art. 10 - Se uma letra incompleta no momento de ser passada tiver sido completada contrariamente aos acordos realizados não pode a inobservância desses acordos ser motivo de oposição ao portador, salvo se este tiver adquirido a letra de má-fé ou, adquirindo-a, tenha cometido uma falta grave.
} 


\subsubsection{Companhia de capital autorizado}

A sociedade anônima se submete ao regime de capital autorizado quando seu estatuto social contém autorização para aumento de capital independentemente de reforma estatutária, consoante art. $168^{89}$ da Lei de Sociedades Anônimas. Segundo ensina Guerreiro, o sistema de capital autorizado consiste em uma faculdade à disposição das sociedades anônimas que pode ser implementada desde a sua constituição ou posteriormente por meio de reforma estatutária. Nessa ocasião, podem ser conferidos ao conselho de administração poderes para aumentar o capital dentro dos limites estabelecidos no estatuto ou a competência pode ser mantida sob a responsabilidade da própria assembléia geral ${ }^{90}$.

Para que se torne eficaz, o art. 168 determina que a autorização deve especificar (i) o limite de aumento (em valor do capital ou em número de ações) e as espécies e classes das ações que poderão ser emitidas; (ii) o órgão competente para deliberar sobre as emissões, (iii) as condições a que podem estiar sujeitas as emissões; (iv) os casos ou as condições em que os acionistas terão direito de preferência para subscrição, ou de inexistência desse direito.

A quantidade de bônus de subscrição que poderá ser emitida pela companhia está sujeita ao número e ao valor das ações referidas no limite estabelecido de capital autorizado, cabendo ao órgão competente da companhia assegurar-se de que a restrição está sendo observada quando da emissão dos títulos ${ }^{91}$.

Esse limite potencial para aumento de capital é justamente a vantagem do capital autorizado para a companhia, na medida em que confere aos titulares de bônus de

\footnotetext{
89 Art. 168. O estatuto pode conter autorização para aumento do capital social independentemente de reforma estatutária.

90 GUERREIRO, José Alexandre Tavares, Regime jurídico do capital autorizado, p. 81. Para aprofundamento sobre a importância do capital social e o regime de capital autorizado, a obra citada aprofunda ainda mais os conceitos que envolvem esses institutos, como se verifica do seguinte trecho extraído da p. 33: "Constituiria simplificação inexata afirmar que, no regime de capital fixo, em que a cifra pertinente consta do estatuto e só pode ser alterada por resoluções da assembleia geral dos acionistas, a origem dos poderes de que se trata restaria concentrada em mãos dos próprios acionistas, ao passo que no regime de capital autorizado, aquela cifra seria mutável, independentemente de reforma estatutária, por deliberação dos órgãos de administração. Para perfeita compreensão do regime de capital autorizado, essa distinção tão sumária quão imperfeita, necessita ser elaborada a partir da própria estrutura jurídica da sociedade anônima conforme se apresenta nas diversas legislações. Tal exame, por sua vez, há de tomar como pressuposto a verificação de que, na estrutura jurídica da sociedade anônima, encontra-se inserida uma organização de poderes, segundo uma idéia finalística."

91 EIZIRIK, Nelson. A Lei das S/A comentada. vol. I, p. 464 e MARTINS, Fran. Comentários à Lei das Sociedades Anônimas, p. 289: "Não se referiu a lei à quantidade de bônus que podem ser emitidos pela sociedade mas esses, naturalmente, deverão corresponder no máximo ao número de ações em que pode ser aumentado o capital".
} 
subscrição (e de outros títulos que conferem direito de subscrição de ações) uma garantia maior em termos de disponibilidade para emissão de novas ações e de que a sua subscrição independerá da convocação dos acionistas para efetivar os procedimentos de aumento de capital $^{92}$.

\subsubsection{Assembleia Geral Extraordinária}

A assembleia geral é o órgão que formalmente expressa a vontade da companhia. Em que pese a lei deixar a cargo desse órgão competências para deliberações de grande relevância na companhia, este não age com soberania, conquanto reparte com os demais órgãos da sociedade as competências necessárias à operacionalização da sua atividade, sob o princípio da separação dos poderes ${ }^{93}$.

É de responsabilidade da assembléia geral, por exemplo, definir as regras e a forma de operação da companhia, em sentido análogo ao funcionamento do poder legislativo (se a sociedade anônima fosse comparada a um país), "na medida em que lá, como aqui, estabelecem-se os quadros jurídicos - estatuto, forma societária, conteúdo patrimonial, no caso da sociedade anônima, e lei, no caso do Estado - dentro dos quais deve se desenrolar a sociedade" ${ }^{94}$. Na prática de muitas sociedades, contudo, as questões a serem submetidas para deliberação dos acionistas são antecipadamente debatidas por meio de reuniões prévias e submetidas à assembleia geral apenas para homologação.

A assembleia geral possui caráter exclusivamente deliberativo e reúne todos os acionistas, com ou sem direito a voto ou com voto restrito. Trata-se do lugar onde o acionista pode exercer o direito de voz. A deliberação resultante da assembleia geral é ato unilateral da companhia, embora decorrente de manifestação de vontade conjunta dos acionistas $^{95}$.

Como afirmado inicialmente, somente a sociedade anônima de capital autorizado pode emitir bônus de subscrição. Internamente, a lei confere à assembleia geral

\footnotetext{
${ }^{92}$ PINTO JUNIOR, Mario Englert. A capitalização da companhia, In: FINKELSTEIN, Maria Eugênia Reis e PROENÇA, José Marcelo Martins (coords.). Sociedades Anônimas, 2. ed., São Paulo: Saraiva, 2011, p. 269. "O detentor do título conversível somente terá segurança quanto à efetividade da conversão se as novas ações prometidas pela companhia não estiverem sujeitas a nenhum ato posterior de vontade dos acionistas para serem criadas. Nesse sentido, a disponibilidade de limite para emissão de novas ações funciona como reserva de estoque em favor do detentor do título conversível".

${ }^{93}$ GUERREIRO, José Alexandre Tavares, Regime jurídico do capital autorizado, p. 34-35.

${ }^{94}$ SALOMÃO FILHO, Calixto. O novo direito societário. 4. ed., rev. e ampl., São Paulo: Malheiros, 2011, pp. 85-86.

${ }_{95}$ EIZIRIK, Nelson. A Lei das S/A comentada, vol. II, p. 14-15.
} 
extraordinária a competência para deliberar sobre essa questão (art. 131), na medida em que a emissão de bônus de subscrição não está entre as competências da assembléia geral ordinária, dispostas no art. 132.

A assembléia geral extraordinária que deliberar sobre a emissão de bônus de subscrição não necessita de quorum qualificado, por não se tratar de hipótese de reforma estatutária (art. 135), podendo ser aprovado a operação por maioria absoluta de votos (art. 129). Em se tratando de companhia fechada, é possível estabelecer quorum especial, nos termos do art. $129, \S 1^{\circ}$.

Deverão, ainda, ser obedecidos os requisitos regulares de convocação de assembleia geral e, em caso de companhia aberta, será necessário fornecer aos acionistas informações sobre direito de preferência, opinião dos administradores sobre os efeitos do aumento de capital, as razões da emissão e o percentual de diluição potencial resultante da emissão (Instrução CVM n ${ }^{\circ}$ 481/2009, art. 15 ${ }^{96}$ ).

\subsubsection{Conselho de administração}

Alternativamente à competência da assembleia geral para deliberar sobre a emissão de bônus de subscrição, de acordo com o art. 76, essa competência poderá ser atribuída, pelo estatuto social, ao conselho de administração.

O conselho de administração, de existência obrigatória para as companhias abertas e de capital autorizado (art. 138), é um órgão colegiado, cujas deliberações devem fixar orientações gerais dos negócios da sociedade, eleger e destituir diretores, entre outras competências estabelecidas no art. 142. A natureza colegiada do conselho de administração, porém, não retira o dever de seus membros exercerem individualmente as atividades de acompanhamento e fiscalização dos diretores ${ }^{97}$. É o órgão que concentra as mais relevantes competências em matéria de administração da sociedade, fortemente

\footnotetext{
${ }^{96} \mathrm{O}$ art. 15 da Instrução CVM no 481/2009 estabelece padrões mínimos de informações que a companhia deve fornecer aos acionistas quando a decisão sobre a emissão de bônus de subscrição ficar a cargo da assembléia geral: Art. 15. Sempre que a assembléia geral dos acionistas for convocada para deliberar sobre emissão de debêntures ou bônus de subscrição, a companhia deve fornecer, no mínimo, as informações indicadas no Anexo 15 à presente Instrução.

${ }^{97}$ OCHMAN, Renato. Atos Societários Relevantes: a Companhia e os Investidores. São Paulo: Impressão Régia, 2013, p. 56.
} 
dominado pelo acionista controlador ${ }^{98}$. Distingue-se da diretoria, a qual corresponde ao órgão que concentra as funções executivas da companhia ${ }^{99}$.

A possibilidade do conselho de administração deliberar sobre a emissão de bônus de subscrição torna a utilização do instituto mais ágil e confere-lhe valor estratégico. Isso porque, com essa vantagem, a emissão do bônus de subscrição prescindirá de toda a formalidade exigida para a convocação de assembleia geral que "requer a publicação do edital por três vezes, sendo (i) na companhia fechada, com oito dias de antecedência, no mínimo, para o primeiro anúncio; não se realizando a assembleia, será publicado novo anúncio, de segunda convocação, e (ii) na companhia aberta, o primeiro anúncio deve ser publicado em um prazo de quinze dias de antecedência" ${ }^{100}$. E, se depois de tudo isso não for atingido o quorum necessário, uma nova publicação com uma antecedência um pouco menor deverá ser providenciada (art. 125).

Assim, considerando a finalidade do bônus de subscrição como mecanismo de capitalização da companhia, a flexibilização das regras para sua emissão permite à sociedade aproveitar as conjunturas de mercado mais favoráveis à emissão desse valor mobiliário.

A propósito da competência estabelecida em lei para determinar a emissão do bônus de subscrição pelo conselho de administração, é oportuno investigar se essa autorização estatutária se revestiria de poderes originários ou se estes derivam da predeterminação dos acionistas da companhia.

Sobre esta questão debruçou-se Guerreiro, comparando o sistema do direito brasileiro, estritamente baseado no capital fixo, e o direito norte-americano que adota o sistema puro de capital autorizado, onde o número de ações passíveis de serem emitidas é designado no articles of incorporation (estatuto social). Nesse caso, a efetiva emissão é objeto de deliberação do board of directors (conselho de administração), que possui, portanto, o poder originário para emissão de authorized shares. Aos acionistas cabe definir o aumento ou diminuição do número de authorized shares mediante reforma estatutária ${ }^{101}$.

\footnotetext{
${ }^{98}$ SALOMÃO FILHO, Calixto. O novo direito societário, p. 101.

${ }^{99}$ BORBA, José Edwaldo Tavares. Direito Societário. Rio de Janeiro: Renovar, 2001, p. 412.

${ }^{100}$ Esse é precisamente o comentário de Francisco Mussnich ao discorrer sobre a alteração na Lei das Sociedades Anônimas pela Lei $\mathrm{n}^{\circ} 12.431$, de 2011, que permite a emissão de debêntures conversíveis em ação pelo conselho de administração, a partir de previsão no estatuto social. MUSSNICH, Francisco Antunes Maciel. As recentes alterações com respeito à competência para emissão de debêntures. In: CASTRO, Rodrigo Rocha Monteiro de; WARDE JÚNIOR, Walfrido Jorge; GUERREIRO, Carolina Dias Tavares. Direito Empresarial e outros estudos de direito em homenagem ao Professor José Alexandre Tavares Guerreiro. São Paulo: Quatier Latin, 2013, p. 547.

${ }^{101}$ GUERREIRO, José Alexandre Tavares. Regime jurídico do capital autorizado, p. 48-49.
} 
A regra na lei brasileira é o sistema de capital fixo (art. $5^{\circ}$ ) que admite a possibilidade de autorização estatutária para aumento de capital sem a necessidade de reforma do estatuto (art. 168). Ou seja, não é a lei que estabelece a possibilidade do conselho de administração deliberar sobre aumento de capital ou emissão de bônus de subscrição, a questão depende de autorização estatutária (art. 166) ${ }^{102}$.

A partir da comparação dos dois sistemas, verifica-se que, com base no ordenamento brasileiro, o aumento de capital não é um poder originário do conselho de administração, de modo que a competência pode ser revogada mediante reforma do estatuto, atividade que compõe a competência privativa da assembleia geral (art. 121). A redação do art. 76 adota essa sistemática: admite a atuação do conselho de administração se este dispuser de autorização estatutária. A definição sobre essa autorização compete à assembléia geral que pode concedê-la ou revogá-la com a alteração do estatuto social. Desse modo, conclui-se que a competência para deliberar o aumento de capital não é imutável e deve ser exercitada pela assembléia geral, caso não haja delegação para o conselho de administração.

\subsubsection{Conselho fiscal}

A participação do conselho fiscal na emissão do bônus de subscrição compreende a atividade de opinar sobre as propostas dos órgãos da administração relativas a essa matéria (art. 163, III). Diferentemente dos demais órgãos, tanto em relação ao bônus de subscrição como também no tocante às demais competências que lhe foram designadas, o conselho fiscal possui atuação de caráter basicamente instrumental, cujo objetivo e função abrangem a fiscalização do conselho de administração e da diretoria, órgãos que realizam atividades típicas de administração da companhia. Em regra, deve se manifestar quanto às contas, a legalidade e a regularidade dos atos de gestão, o que inclui tanto os atos dos executivos como de seus subordinados.

Tão importante quando a função fiscalizadora é a finalidade informativa enfatizada por Guerreiro ao afirmar que "o conselho fiscal é, por excelência - e a bem dizer por

102 GUERREIRO, José Alexandre Tavares. Regime jurídico do capital autorizado, p. 81: “os poderes deferidos ao conselho de administração para promover aumentos de capital dentro dos limites estatutários são derivados do estatuto e não exsurgem iure proprio aos gestores sociais, com a peculiaridade, ainda, de que a própria assembleia geral pode ser órgão competente para deliberar sobre as emissões, segundo se verifica da leitura do art. $168, \S 1^{\circ}, b$. 
definição - órgão destinado a transmitir aos acionistas as informações de que necessitam, quer para exercerem o direito essencial de fiscalizar a gestão dos negócios sociais, quer para que possam votar, na assembleia geral, com conhecimento de causa"103. Complementarmente, ressalta que essa atribuição para informar a assembléia geral encontra-se também indicada na exposição de motivos da lei de sociedades anônima.

Nos termos do art. 161, a existência do conselho fiscal é obrigatória, no entanto o seu funcionamento é opcional, podendo ser permanente ou eventual, na forma estabelecida pelo estatuto social ${ }^{104}$, exceto para as sociedades de economia mista para as quais a lei prevê operação permanente (art. 240).

É considerado um órgão colegiado, em virtude da forma de eleição, substituição e destituição de seus membros, além do fato de suas deliberações serem tomadas mediante voto $^{105}$ em reuniões que dependem de regular convocação e instalação. A atuação individual de seus membros, admitida pelo art. $163, \S 2^{\circ}$, confere ao órgão um modelo híbrido, pois conjuga a atuação colegiada com a possibilidade de seus conselheiros atuarem de forma singular solicitando esclarecimentos e informações que entenderem necessários.

A atuação do órgão, entretanto, está circunscrita à função e ao espaço que a lei lhe impõe. Nesse sentido, não há relação hierárquica entre os membros do conselho fiscal e do conselho de administração e diretores; os integrantes do conselho fiscal devem exercer suas atividades de acordo com o interesse da companhia, de modo que estes prevaleçam sobre o dos acionistas (especialmente daqueles que os elegerem); e o órgão não realiza controle de conveniência e oportunidade relativamente a decisões empresariais adotadas pelos diretores e pelo conselho de administração, exceto quando a lei atribuir-lhe expressamente tal competência ${ }^{106}$.

No que concerne o objeto deste estudo, por expressa disposição legal, caberá ao conselho fiscal opinar sobre as propostas dos órgãos da administração relativas à emissão de bônus de subscrição, no sentido de verificar a sua adequação aos termos legais e às condições apresentadas pela sociedade.

${ }^{103}$ GUERREIRO, José Alexandre Tavares. O conselho fiscal e o direito a informação, In: Revista de Direito Mercantil, Industrial, Econômico e Financeiro, São Paulo: Revista dos Tribunais, v. 45, jan./mar., 1982, p. 30.

${ }^{104}$ BORBA, José Edwaldo Tavares. Direito Societário, pp. 442-443.

${ }^{105}$ BULGARELLI, Waldirio. Regime Jurídico do Conselho Fiscal das S/A, Rio de Janeiro: Renovar, 1998, p. 71.

${ }^{106}$ EIZIRIK, Nelson. Limites à atuação do conselho fiscal, In: Revista de Direito Mercantil, Industrial, Econômico e Financeiro, São Paulo: Revista dos Tribunais, v. 84, out./dez., 1991, p. 18. 


\subsubsection{Investidor}

A lei das sociedades anônimas não faz qualquer restrição em relação à pessoa que poderá adquirir o bônus de subscrição. De acordo com o art. $2^{\circ}$ da Instrução CVM n ${ }^{\circ}$ 400/2003, a oferta pública de distribuição de valores mobiliários a pessoas naturais, jurídicas, fundo ou universalidade de direitos, residentes, domiciliados ou constituídos no Brasil deve ser submetida a registro perante a Comissão de Valores Mobiliários, o que denota não haver limitação subjetiva para a aquisição dos títulos, além da capacidade civil prevista pelo Código Civil para a realização de qualquer negócio jurídico (art. 104 do Código Civil).

Para a distribuição pública dos bônus de subscrição, dependendo do grau de conhecimento e especialização do investidor a que é destinada a colocação de valores mobiliários, é ampliada ou reduzida a proteção e o volume de informações que a Comissão de Valores Mobiliários exige da companhia emissora para registrar ou, por outro lado, autorizar a dispensa de registro da oferta pública ${ }^{107}$.

Tanto na emissão privada como na distribuição pública, independentemente das disposições da Comissão de Valores Mobiliários acima referidas, caberá à companhia decidir sobre a limitação subjetiva para aquisição do bônus de subscrição, considerando o objetivo da emissão.

\subsubsection{Comissão de Valores Mobiliários}

A Comissão de Valores Mobiliários é uma autarquia criada com a função regulamentar o mercado de capitais ${ }^{108}$ com competência para expedir normas e exercer poder disciplinar sobre companhias abertas, fiscalizando as atividades e os serviços prestados no âmbito do mercado de valores mobiliários ${ }^{109}$.

\footnotetext{
${ }^{107}$ No Processo CVM n ${ }^{\circ}$ RJ/2006/645, foi autorizada a dispensa de Requisito de Registro da Oferta Pública de distribuição de bônus de subscrição de ações ordinárias em virtude de ser negociado na Bovespa e apresentar liquidez diária, bem como em virtude do valor mobiliário ter seu preço derivado da cotação da ação ordinária que compõe a carteira do IBOVESPA. No Processo CVM nº RJ 2009/9251, foi concedido registro para negociação de bônus de subscrição na Bolsa com dispensa de elaboração do prospecto, por entender o colegiado que o mercado estava devidamente informado acerca do emissor e dos valores mobiliários emitidos.

${ }^{108}$ KÜMPEL, Siegfried. Direito do Mercado de Capitais: do ponto de vista europeu, alemão e brasileiro. Rio de Janeiro: Renovar, 2007, p. 15.

${ }^{109}$ Cf. art. $8^{\circ}$ da Lei ${ }^{\circ} 6.385 / 76$.
} 
Caso a emissão de bônus de subscrição ocorra sob a forma de distribuição pública, é necessário que a companhia efetue o registro de emissor na Comissão de Valores Mobiliários, nos termos do art. $4^{\circ}, \S^{\circ 110}$ e do art. $1^{\circ}$ da Instrução CVM no 480, de 2009, além do registro de oferta publica de distribuição de valores mobiliários ${ }^{111}$, consoante exige o art. $19^{112}$ da Lei ${ }^{\circ}$ 6.385/76 regulamentado pela Instrução CVM n ${ }^{\circ} 400$, de 2003.

O registro na Comissão de Valores Mobiliários não tem como objetivo a análise do mérito do investimento oferecido pelo emissor, mas a verificação do cumprimento das regras que visam proteger o investidor, garantindo a prestação pela companhia de informações mínimas sobre os valores mobiliários a serem distribuídos ${ }^{113}$.

Em virtude do alto custo que o registro da oferta pública de valores mobiliários acarreta para a companhia, cabe referir a possibilidade de dispensa do registro, com base nos artigos $4^{\circ}$ e seguintes da Instrução CVM n ${ }^{\circ} 400 / 2003$, a qual compreende critérios como o valor unitário dos valores mobiliários ofertados ou o valor total da oferta, o plano de distribuição dos valores mobiliários, o público destinatário da oferta, entre outros. A dispensa de registro envolve, normalmente, operações de distribuição de valores mobiliários com esforços restritos de colocação quando se destina aos acionistas da companhia ou a um círculo restrito de investidores com relacionamento junto à emissora $^{114}$.

Caso a emissão seja realizada de forma privada por companhia fechada, não caberá à Comissão de Valores Mobiliários a tarefa de fiscalizar a emissão dos títulos. Nesse caso, a distribuição privada também não implicará em registro ou participação de instituição financeira (artigos $4^{\circ}$ e 82). Apenas a companhia de capital aberto deverá prestar informações, tendo em vista o que estabelece a Instrução CVM nº 480/2009 sobre o

\footnotetext{
${ }^{110}$ Lei ${ }^{\circ}$ 6.404/76, Art. $4^{\circ}$ Para os efeitos desta Lei, a companhia é aberta ou fechada conforme os valores mobiliários de sua emissão estejam ou não admitidos à negociação no mercado de valores mobiliários.

$\S 1^{\circ}$ Somente os valores mobiliários de emissão de companhia registrada na Comissão de Valores Mobiliários podem ser negociados no mercado de valores mobiliários.

${ }^{111}$ CINTRA, Maria Lucia Borges de Araújo. Aspectos jurídicos dos bônus de subscrição, p. 103.

${ }^{112}$ Lei $\mathrm{n}^{\circ}$ 6.385/76, Art. 19. Nenhuma emissão pública de valores mobiliários será distribuída no mercado sem prévio registro na Comissão.

${ }_{113}$ EIZIRIK, A Lei das S/A comentada, vol. I, p. 66-67: "O exame do mérito cabe unicamente aos investidores do mercado e o registro apenas garante que as informações exigidas foram, prestadas, encontrando-se à sua disposição. (...) A única hipótese prevista na Lei das S.A. de exame substantivo por parte da Comissão de Valores Mobiliários é aquela, de rara ocorrência na prática, referente à constituição da companhia por subscrição pública (artigo 82)"

${ }^{114}$ A título exemplificativo, cabe mencionar o julgamento pelo órgão colegiado da Comissão de Valores Mobiliários a respeito do pedido perante a dispensa de elaboração de prospecto para a negociação de bônus de subscrição com origem em subscrição privada de ações, objeto do Processo CVM no RJ 2008/11861. No julgamento, foi concedida dispensa de registro para negociação de bônus de subscrição na BM\&FBOVESPA, tendo em vista que as informações necessárias para negociação foram disponibilizadas publicamente pela companhia (quantidade, preço de exercício e prazo de exercício).
} 
registro de emissores de valores mobiliários admitidos à negociação em mercados regulamentados de valores mobiliários.

\subsection{Elementos objetivos}

Nesse próximo ponto, serão analisados os elementos objetivos do bônus de subscrição, bem como os requisitos necessários para a sua emissão, com base nos parâmetros estabelecidos na legislação e interpretados pela doutrina pátria.

\subsubsection{Objeto e Finalidade}

O objeto do bônus de subscrição compreende o direito do seu titular de subscrever novas ações em determinado prazo e de acordo com critérios especificados na deliberação do órgão competente da companhia emissora. As ações que serão subscritas por ocasião do exercício do bônus de subscrição correspondem a emissões primárias da companhia, até o limite do capital autorizado.

Tanto o bônus de subscrição destinado à alienação como título autônomo quanto aquele emitido para ser atribuído na subscrição de ações ou debêntures da sociedade, tem como finalidade a mobilização de recursos para a companhia ${ }^{115}$, seja diretamente quando houver o exercício do bônus de subscrição, seja no fato do título ajudar na colocação dos valores mobiliários antes mencionados.

O propósito do bônus de subscrição que se extrai da lei é o de aproveitar as conjunturas do mercado para obter recursos para a sociedade ${ }^{116}$, o qual, na origem do instituto no direito norte-americano, já estava indicado. Todavia, na prática societária, outros efeitos jurídicos são objetivados quando da emissão de bônus de subscrição,

115 TEIXEIRA, Egberto Lacerda; GUERREIRO, José Alexandre Tavares. Das Sociedades Anônimas no Direito Brasileiro, p. 325.

${ }^{116}$ Para Guerreiro, "os títulos em questão funcionam como instrumento de captação de recursos para o giro social, cuja utilidade reside exatamente no aproveitamento de certas conjunturas do mercado, para lembrar a expressão constante da Exposição de Motivos da Lei n. 6.404. O momento pode não ser adequado para o lançamento de um aumento de capital, ou, na hipótese inversa, condições conjunturais podem ser propícias a tanto, mas a companhia não pode aparelhar-se tempestivamente para se valer da conjuntura favorável. $\mathrm{O}$ atendimento dessas necessidades ou conveniências empresariais se vê amplamente facilitado pelo uso dos bônus de subscrição, alienados pela companhia na ocasião oportuna, ao cabo de um procedimento simplificado que dispensa as formalidades assembleares na medida em que admite que a deliberação respectiva seja tomada pelo conselho de administração". GUERREIRO, José Alexandre Tavares. Regime Jurídico do Capital Autorizado, p. 121. 
conforme será demonstrado no Capítulo 5. Nessa parte, descreveremos como o título é utilizado na qualidade de instrumento de diluição de acionistas para, por exemplo, atender a metas de investimento estabelecidas em acordo de acionistas ou para regularizar a participação acionária decorrente da entrada de fundo de investimento na sociedade emissora, quando a proporção do aporte em relação ao valor da companhia somente é consolidado após a data do fechamento do negócio.

Para Kohler, é possível identificar outra utilidade para o bônus de subscrição. Segundo ele, a emissão do título poderá ser usada para fins de pesquisa de mercado, de modo a testar a resposta do mercado frente a uma eventual colocação de ações ou debêntures da companhia ${ }^{117}$.

Assim, em que pese não estarem previstas essas outras formas de utilização do bônus de subscrição, a prática societária tem criado formas de atender a suas necessidades com o emprego de usos alternativos para o instituto, os quais devem ser levados em consideração quando analisada a emissão de bônus de subscrição.

\subsubsection{Requisitos}

São requisitos essenciais do bônus de subscrição (i) a deliberação da assembléia geral ou do conselho de administração de sociedade anônima sob o regime de capital autorizado determinando a sua emissão e fixando (ii) o preço de emissão ou a sua atribuição gratuita, (iii) o prazo para o seu exercício, (iv) o preço de subscrição das novas ações ou os critérios determiná-lo e (v) a quantificação e a qualificação das ações a serem emitidas. A seguir, apresentaremos individualmente os aspectos mais importantes de cada um deles.

\subsubsection{Deliberação da assembléia geral ou do conselho de administração}

Consoante já explicitado anteriormente, a emissão do bônus de subscrição pode decorrer de deliberação de assembléia geral extraordinária ou do conselho de

\footnotetext{
${ }^{117}$ KOHLER, Claudio. Bônus de Subscrição, p. 97: "Por meio da emissão de bônus de subscrição é possível verificar a resposta do mercado a uma eventual colocação de ações ou até de debêntures. Possibilitando à companhia planejar melhor a colocação de ações e até de debêntures no mercado, o bônus tornas-esse importante instrumento para a redução de custos na colocação dos títulos mencionados".
} 
administração. Na primeira hipótese, a deliberação da assembléia geral consistirá no resultado da aprovação pela maioria dos acionistas com direito a voto não se computando os votos em branco (art. 129).

Se o estatuto social autorizar a emissão pelo conselho de administração, a deliberação será fruto da maioria de votos dos membros do conselho de administração, exceto se o estatuto prever quorum qualificado (art. 140, IV).

A ata que contém a deliberação da assembléia geral deve ser necessariamente publicada e arquivada perante a Junta Comercial competente e, em caso de companhia aberta, há a obrigação de enviar uma cópia da ata à Comissão de Valores Mobiliários e à Bolsa de Valores em que os valores mobiliários serão negociados (art. 13, §3 , Instrução $\mathrm{CVM} \mathrm{n}^{\circ} 480 / 2009^{118}$ ).

A ata relativa às deliberações do conselho de administração apenas serão objeto de arquivamento e publicidade quando contiverem deliberação destinada a produzir efeitos perante terceiros ( $\operatorname{art} 142, \S 1^{\circ}$ ), como é o caso da emissão de bônus de subscrição.

A esse respeito, vale acrescentar a necessidade de divulgação de informação sobre a emissão de bônus de subscrição, conforme estabelece o art. $157, \S 4^{\circ 119}$ reforçando o dever de informar dos administradores perante o mercado com o objetivo de tornar mais eficiente o processo de formação de preços dos valores mobiliários negociados e reduzir as possibilidades de insider trading ${ }^{120}$.

Além disso, no que tange os efeitos da deliberação, a emissão de bônus de subscrição não acarreta para o acionista dissidente o direito de retirada ${ }^{121}$ (art. 137), na medida em que a matéria não se encontra dentre aquelas listadas no art. 136.

\subsubsection{Preço de emissão do bônus de subscrição}

O preço de emissão do bônus de subscrição refere-se ao valor que o adquirente deverá pagar pelo direito futuro de subscrever ações. Esse preço não corresponde ao valor

\footnotetext{
118 Instrução CVM n 480/2009, Art. 13. O emissor deve enviar à CVM as informações periódicas e eventuais, conforme conteúdo, forma e prazos estabelecidos por esta Instrução. (...)

$\S 3^{\circ}$ As informações enviadas à CVM nos termos do caput devem ser entregues simultaneamente às entidades administradoras dos mercados em que valores mobiliários do emissor sejam admitidos à negociação, na forma por elas estabelecida.

${ }^{119} \S 4^{\circ}$ Os administradores da companhia aberta são obrigados a comunicar imediatamente à bolsa de valores e a divulgar pela imprensa qualquer deliberação da assembléia-geral ou dos órgãos de administração da companhia, ou fato relevante ocorrido nos seus negócios, que possa influir, de modo ponderável, na decisão dos investidores do mercado de vender ou comprar valores mobiliários emitidos pela companhia.

${ }^{120}$ EIZIRIK, Nelson. A Lei das S/A Comentada, vol. II, pp. 391-392.

${ }^{121}$ LOPES, Mauro Brandão, S.A.: Títulos e Contratos Novos, São Paulo: Revista dos Tribunais, 1978, p. 807.
} 
da ação que será subscrita, mas ao montante que o investidor paga apenas para dispor do direito de subscrever, no futuro, novas ações da companhia.

Sobre o preço de emissão, é importante referir que, diferentemente do que ocorre em relação a outros valores mobiliários, aquele não é reembolsado ao investidor caso opte por não subscrever as ações que o bônus de subscrição lhe possibilita. Isso porque a quantia inicial investida corresponde justamente ao pagamento pelo direito de optar futuramente por adquirir ações da companhia em situação mais vantajosa (em virtude da pré-determinação do preço da ação e da expectativa de valorização das ações da companhia no mercado acima do montante fixado). Ou seja, o preço de subscrição do título corresponde à vantagem financeira e estratégica que o seu titular adquire - em situação favorável de mercado - frente a investidores que, no momento do exercício, se submetem ao preço de mercado.

Em regra, o titular do bônus de subscrição exercerá seu direito de subscrever novas ações caso o preço predeterminado seja inferior ao praticado no mercado, na medida em que na hipótese inversa, seria menos custoso adquirir ações negociadas na bolsa de valores ou no mercado de balcão. Em relação às companhias fechadas, por não terem cotação pública, a avaliação sobre preço de exercício do bônus de subscrição dependerá de critérios como balanço patrimonial, condições gerais do mercado em que esteja inserida a empresa e outros que tenham impacto sobre o investimento em ações.

Diversamente do preço de subscrição das ações, o preço de emissão do bônus de subscrição não foi regulamentado pela lei, o que permite à companhia defini-lo com base em elementos financeiros. É possível, ainda, que o bônus de subscrição seja atribuído gratuitamente a subscritores de ações e debêntures, de modo que tal emissão terá caráter gratuito.

Em conformidade com o art. 182, $\S 1^{\circ}$, "b"122, o produto da alienação dos bônus de subscrição será classificado como reserva de capital. Assim, o resultado da alienação do bônus de subscrição não integrará a conta do capital social, mas constituirá reserva de capital $^{123}$, podendo ser utilizado para absorver prejuízos, resgatar ações, entre outros (art. 200).

\footnotetext{
${ }^{122}$ Art. 182. A conta do capital social discriminará o montante subscrito e, por dedução, a parcela ainda não realizada.

$\S 1^{\circ}$ Serão classificadas como reservas de capital as contas que registrarem: (...)

b) o produto da alienação de partes beneficiárias e bônus de subscrição; (...)

123 MARTINS, Fran. Comentários à Lei das Sociedades Anônimas, p. 287.
} 
A lei também não exige que o bônus de subscrição tenha valor nominal. Caberá à sociedade emissora apenas determinar o valor de sua emissão, já que o valor de negociação no mercado secundário varia de acordo as leis de mercado ${ }^{124}$ e em virtude dos dados que balizam o interesse do investidor nas futuras novas ações, tais como cotação e volatilidade das ações, expectativa de rentabilidade, distribuição de dividendos, entre outros ${ }^{125}$.

Por vezes, a negociação de bônus de subscrição pode oferecer ganhos e vantagens mais expressivas que a compra e venda de ações, como ilustra Paulo Aragão em artigo que lança uma interessante análise hipotética sobre as vantagens da negociação desse título. Segundo ele:

“o preço de mercado para a ação de certa companhia é de $\mathrm{Cz} \$ 20,00$ e o bônus de subscrição assegura a seu titular o direito a subscrever a ação da mesma classe ao valor de $\mathrm{Cz} \$ 25,000$, durante um prazo decadencial de três anos. O investidor que se dispuser a adquirir o bônus de subscrição estará especulando com a possibilidade de que, durante aquele triênio, o preço de mercado de ação chegue a mais de $C z \$ 25,00$ e a subscrição da mesma, seguida ou não da venda da ação subscrita, venha a representar uma possibilidade de lucro. (....) Se efetivamente a ação ultrapassa o preço de subscrição previsto no bônus de subscrição e chega a Cz\$26,00, o valor de mercado do bônus de subscrição, considerados todos os fatores antes referidos, deverá situar-se em torno de Cz\$ 1,00, que correspondem à vantagem imediatamente realizável com a subscrição de ações a $\mathrm{Cz} \$ 25,00$ e a sua venda a $\mathrm{Cz} \$ 26,00$, sem considerar as despesas de corretagem. Ora se a ação continuar subindo de preço e de $\mathrm{Cz} \$ 26,00$ chegar a Cz\$ 28,00, os acionistas terão obtido, sempre sem considerar os custos de corretagem, ganho de $\mathrm{Cz} \$ 2,00$ ou 7,69\% apenas. No mesmo período, e por iguais razões, o bônus de subscrição deverá estar cotado em torno de $\mathrm{Cz} \$ 3,00$ (isto é, a diferença entre $\mathrm{Cz} \$ 25,00$, que é o preço de subscrição garantido do bônus, e o preço de mercado de $\mathrm{Cz} \$ 28,00)$ e os seus titulares terão obtido, em

\footnotetext{
${ }^{124}$ KOHLER, Claudio. Bônus de Subscrição, p. 104.

125 Paulo Aragão acrescenta outros fatores que contribuem para a determinação do valor do bônus de subscrição como "o prazo de duração do direito à subscrição e a taxa de juros vigente no mercado (pois pode ser mais interessante aplicar hoje $\mathrm{Cz} \$$ numa caderneta de poupança e aguardar para subscrever a mesma ação daqui a três anos com apenas uma pequena fração do investimento original". ARAGÃO, Paulo Cezar. Opções de Compra de Ações e Bônus de Subscrição, p. 69-70
} 
igual período, um ganho de $200 \%$, o que não é inusitado na experiência norteamericana" 126 .

O preço de emissão do bônus de subscrição corresponde, portanto, ao valor atribuído pelo órgão da administração responsável pela deliberação da emissão, não guardando necessariamente relação com o preço de subscrição de ações cujo direito é conferido pelo bônus de subscrição, exceto pelo fato de que o preço de emissão naturalmente compõe o cálculo econômico necessário para garantir a demanda por esse valor mobiliário.

De acordo com Carvalhosa, a contraprestação devida pela aquisição do bônus de subscrição em sua modalidade onerosa pode ser feita em dinheiro e também "por troca ou compensação de bens adquiridos, serviços prestados ou como remuneração de royalties ou de assistência técnica" ${ }^{\prime 27}$. Conforme já foi dito, o preço de emissão não possui parâmetros legais, de modo que o referido autor sugere levar em conta, para sua fixação, a projeção dos resultados de exercícios futuros e fatores como intangíveis da companhia, cotação média na bolsa. E, para que esse preço não importe em pagamento de "ágio pela prosperidade da companhia" indica que o valor deve situar-se em patamar não superior a $5 \%$ do valor patrimonial da ação no momento da emissão do bônus de subscrição ${ }^{128}$.

\subsubsection{Prazo para exercício do bônus de subscrição}

De acordo com o art. 79, V, o certificado do bônus de subscrição deverá declarar “a época em que o direito de subscrição poderá ser exercido e a data do término do prazo para esse exercício". Não sendo obrigatória a emissão de certificado, entendemos que o art. 79 não pode ser tomado como indicador dos requisitos indispensáveis ao bônus de subscrição. O que define dado elemento como requisito indispensável do título é a sua função na estrutura do bônus de subscrição, considerado também o seu contexto do mercado de capitais. Isto é, dentre as informações indicadas na lei relativamente ao bônus de

\footnotetext{
${ }^{126}$ ARAGÃO, Paulo Cezar. Opções de Compra de Ações e Bônus de Subscrição, p. 69-70.

${ }^{127}$ CARVALHOSA, Modesto. Comentários à Lei de Sociedades Anônimas, vol. II, p. 79.

${ }^{128}$ CARVAlHOSA, Modesto. Comentários à Lei de Sociedades Anônimas, vol. II, p. 80: "Por tudo isso, o preço do bônus deverá representar um valor não superior, via de regra, a 5\% do valor patrimonial da ação, no momento de sua emissão. Ultrapassando-se esse percentual, poderá ficar economicamente agravado o direito de preempção dos acionistas. Poder-se-ia argumentar que teriam eles a vantagem de subscrever, futuramente, o capital por valor patrimonial antigo. Mas, de qualquer forma, estariam pagando injustificado ágio sobre o próprio valor patrimonial originado de suas anteriores contribuições de capital".
} 
subscrição, serão considerados requisitos para sua emissão aqueles que se mostrem imprescindíveis para promover a previsibilidade e a estabilidade do título no mercado.

É por essa razão que, por exemplo, os dados referentes ao valor do capital social, à data do ato que tiver fixado o capital social, o número de ações em que este se divide e o valor nominal das ações ou a declaração de que não têm valor nominal indicados no art. 79, I (por referência ao art. 24, II), não devem ser considerados como requisitos do bônus de subscrição. Apesar de serem relevantes para a emissão do título junto a investidores, este poderá ser considerado validamente emitido, independentemente de abranger estas informações.

Pela mesma razão, é irrelevante indicação da "data da emissão do certificado e as assinaturas de dois diretores", na medida em que esses itens apenas se justificam caso sejam emitidos certificados. Do contrário, as assinaturas realmente necessárias são aquelas constantes na ata que contém a deliberação da assembléia geral ou do conselho de administração para emissão de bônus e subscrição.

Por outro lado, considerando que o prazo para exercício do bônus de subscrição é extremamente relevante para a operacionalização do título no mercado, sua previsibilidade e estabilidade, entendemos que este deve ser indicado quando da sua emissão ${ }^{129}$, não se admitindo o bônus de subscrição perpétuo ${ }^{130}$.

O prazo pode ser tanto a indicação do termo inicial e final para o exercício do bônus de subscrição como a data determinada para essa finalidade. Em qualquer hipótese, tem natureza decadencial, de modo que, após o seu transcurso, extingue-se o direito do titular de subscrever ações da companhia e a relação jurídica existente entre investidor e sociedade emissora.

Para Carvalhosa, o prazo para exercício do bônus de subscrição não poderia ser inferior a 30 dias, de modo a permitir a exequiibilidade do direito de preferência ${ }^{131}$. Cabe lembrar, entretanto, que o direito de preferência pode ser excluído por previsão estatutária ou o seu prazo de exercício reduzido, nos termos do art. 172.

\footnotetext{
${ }^{129}$ LAMY FILHO, Alfredo; PEDREIRA, José Luiz Bulhões (coord.). Direito das Companhias. Rio de Janeiro: Forense, 2009, p. 652.

${ }^{130} \mathrm{O}$ bônus de subscrição emitido em caráter perpétuo é possível no direito norte-americano, consoante se observa da redação do §157 do Delaware Code e também do §6.24 do Model Business Corporation Act que admite sejam incluídas restrições ou condições que "obstem ou limitem do exercício" dos direitos e opções previstos nesse dispositivo, o qual inclui o bônus de subscrição.

${ }^{131}$ CARVALHOSA, Modesto. Comentários à Lei de Sociedades Anônimas, vol. II, p. 91.
} 


\subsubsection{Preço de subscrição da ação}

O preço para subscrição das novas ações que serão emitidas pela companhia em decorrência do exercício do bônus de subscrição é um dos fatores mais importantes no tratamento deste tema, tendo em vista o fato de que o preço não precisa ser determinado, mas somente determinável. Esta possibilidade confere ao título a aptidão de motivar o investidor a adquirir o título diante da potencial vantagem financeira que terá mediante a subscrição de ações em um cenário de valorização das ações no mercado em relação ao montante definido quando da emissão do bônus de subscrição.

De acordo com o inciso ÌV do art. 79, para emissão do bônus de subscrição, é necessário informar os critérios para determinar o preço de subscrição das novas ações às quais o título dá direito, não sendo obrigatório indicar esse valor expressamente ${ }^{132}$. O preço de subscrição das ações deverá oferecer critérios que permitam o cálculo no momento do exercício e, considerando que as ações a que dão direito o bônus de subscrição resultam de aumento de capital por subscrição de pública ou privada de ações, a determinação do seu preço está sujeita aos parâmetros estabelecidos pelo art. $170, \S 1^{\circ 133}$.

A redação anterior do mencionado dispositivo provocou grande discussão doutrinária e jurisprudencial acerca da necessidade de aplicação conjunta (ou independente) dos critérios legais para determinação do preço de subscrição da ação, de modo que foi editada a Lei $\mathrm{n}^{\circ}$ 9.457/1997 para incluir a expressão "alternativa ou conjuntamente" no $\S 1^{\circ}$ e explicitar a desnecessidade dos mencionados parâmetros incidirem concomitantemente ${ }^{134}$. A nova redação flexibilizou, ainda, a vinculação do preço de subscrição à "cotação das ações no mercado" ao admitir "ágio ou deságio em função das condições do mercado". A alteração legislativa encerrou, portanto, a polêmica sobre a emissão de ação com ágio ou deságio em relação ao valor original, ratificando o sistema do bônus de subscrição, tendo em vista que, caso não houvesse a possibilidade de um deságio

\footnotetext{
132 TEIXEIRA, Egberto Lacerda; GUERREIRO, José Alexandre Tavares. Das Sociedades Anônimas no Direito Brasileiro, p. 325.

133 Art. 170. Depois de realizados $3 / 4$ (três quartos), no mínimo, do capital social, a companhia pode aumentá-lo mediante subscrição pública ou particular de ações.

$\S 1^{\circ}$ O preço de emissão deverá ser fixado, sem diluição injustificada da participação dos antigos acionistas, ainda que tenham direito de preferência para subscrevê-las, tendo em vista, alternativa ou conjuntamente:

I - a perspectiva de rentabilidade da companhia;

II - o valor do patrimônio líquido da ação;

III - a cotação de suas ações em Bolsa de Valores ou no mercado de balcão organizado, admitido ágio ou deságio em função das condições do mercado.

134 ROSMAN, Luiz Alberto Colonna, Modificação do capital social, In: LAMY FILHO, Alfredo; PEDREIRA, José Luiz Bulhões (coord.). Direito das Companhias. Rio de Janeiro: Forense, 2009, p. 1.409.
} 
no preço de subscrição das ações em relação ao valor de mercado, não haveria interessados no exercício do título.

A definição do valor de subscrição de ações deve fazer parte da deliberação que determina emissão do bônus de subscrição e constitui uma decisão discricionária da companhia ${ }^{135}$. Por exemplo, em relação à companhia cujas ações integram os índices da bolsa de valores e, portanto, dispõem de presunção de liquidez, é adequado utilizar-se os critérios de fixação do preço com base na sua cotação no mercado. O mesmo critério provavelmente não será apropriado para ações que possuem baixa negociabilidade tanto em valor como em volume no mercado, devendo-se privilegiar outro parâmetro legal que acomode melhor o caso concreto ${ }^{136}$.

O bookbuilding é o procedimento normalmente adotado por bancos de investimentos que operacionalizam a oferta pública de ações de companhias abertas com a finalidade de determinar o preço de subscrição organizando a coleta de intenções de subscrição por parte de investidores institucionais ${ }^{137}$. Esse é um método relevante para dar maior segurança ao preço de subscrição das ações no sentido de que este atenderá ao interesse não apenas dos acionistas, mas também da companhia.

Quanto ao critério do inciso I (art. $170, \S 1^{\circ}$ ), a perspectiva de rentabilidade está amparada "no direito do acionista participar nos lucros sociais e é igual ao valor atual (descontado para o presente) do fluxo esperado de renda que caberá à ação no futuro"138 . Um dos métodos que permite chegar a esse preço é o do fluxo de caixa descontado. A escolha da metodologia dependerá do tipo de empresa, pois de acordo com a atividade ou o setor em que atua a companhia (indústria, serviço, comércio), há critérios mais adequados para avaliar economicamente o seu valor.

No inciso II (art. $170, \S 1^{\circ}$ ), a lei indica o critério do valor do patrimônio líquido, o qual corresponde à quantidade de patrimônio dividido pelas ações da companhia em dado momento. Em outras palavras, o valor do patrimônio líquido da companhia é representado pelo "valor dos lançamentos contábeis, não se exigindo, de modo algum, que a companhia promova previamente a reavaliação do seu ativo, ou de qualquer modo, leve em

\footnotetext{
${ }^{135}$ EIZIRIK, Nelson. A Lei das S/A Comentada, vol. II, p. 497: “A escolha dos parâmetros para a fixação do preço de emissão constitui decisão discricionária da companhia. Não pode o acionista minoritário contestá-la por entender que não são os mais adequados, exceto se demonstrar a ilegalidade da decisão".

136 TOMAZETTE, Marlon. Direito Societário, p. 245.

${ }^{137}$ PINTO JUNIOR, Mario Englert. A capitalização da companhia, p. 274.

${ }^{138}$ ROSMAN, Luiz Alberto Colonna, Modificação do capital social, p. 1.415.
} 
consideração o valor de mercado dos ditos bens" 139 porquanto a redação do dispositivo assim não exige. Quando há necessidade de estabelecer o valor do patrimônio líquido a preços de mercado, a lei das sociedades anônimas faz referência expressa, como se nota em relação aos artigos 256, II, “b” e 264.

Considerando que o patrimônio líquido é uma cifra verificável em qualquer companhia, este é o critério mais acessível para fundamentar o preço de subscrição de ações de sociedades anônimas fechadas e, em virtude dele representar um valor contábil, não econômico, frequentemente é aliado ao critério da perspectiva de rentabilidade da companhia $^{140}$.

Além da relevância sobre a atratividade do título, o preço de subscrição de ações tem importante repercussão sobre a análise da diluição injustificada dos acionistas que não exercem o direito de preferência, o que será objeto de análise específica no item 2.5 deste capítulo. A fim de coibir a diluição indevida, o $\$ 7^{\circ}$ do art. 170 exige que a escolha do critério para cálculo do preço de subscrição das ações seja evidenciada na proposta de aumento de capital de modo a justificar os aspectos econômicos que a motivaram.

\subsubsection{Qualificação e quantidade das novas ações}

O último requisito para que seja considerada regular a emissão de bônus de subscrição é a determinação da quantidade e da qualificação das ações a serem subscritas, tendo em vista que as ações de uma companhia podem oferecer diferentes direitos e vantagens aos seus titulares, de acordo com a espécie e a classe a que pertencem.

A lei das sociedades anônimas admite duas espécies de ações: ordinária e preferencial $^{141}$. As ações ordinárias compreendem a participação acionária que

\footnotetext{
${ }^{139}$ COMPARATO, Fabio Konder. A Fixação do Preço de Emissão das Ações no Aumento de Capital de Sociedade Anônima. Revista de Direito Mercantil, Industrial, Econômico e Financeiro. São Paulo, Ano XXX, n. 81, Jan./mar, p. 84.

${ }^{140}$ PENTEADO, Mauro Rodrigues. Aumentos de Capital das Sociedades Anônimas. 2 ed., atual., e anotado por Alfredo Lazzareschi Neto, São Paulo: Quartier Latin, 2012, p. 135.

${ }^{141} \mathrm{O}$ art. 15 da lei de sociedades anônimas também admite a emissão de ação de fruição que é aquela distribuída ao acionista quando sua ação, ordinária ou preferencial, é amortizada, isto é, quando a sociedade distribui ao acionista, a título de antecipação e sem redução do capital social, quantias que lhes poderiam tocar em caso de liquidação da companhia, nos termos do art. 44 da mesma lei. A hipótese do bônus de subscrição dar direito a subscrever ações de fruição nos parece remota, de modo que restringiremos a abordagem às espécies ordinária e preferencial. Para COSTA, Philomeno J. da, Anotações às Companhias, vol. I, São Paulo: Revista do Tribunais, 1980, pp. 265-266: as ações de fruição não correspondem a uma terceira espécie do gênero "ação", porquanto essas podem ser ações ordinárias ou preferenciais "com a particularidade de que não representam mais contribuição no capital social; a fração que lhe correspondia foi devolvida ao seu titular e, não obstante isto, ele é considerado acionista para os demais efeitos".
} 
necessariamente confere direito a voto nas deliberações da assembleia geral, sendo, portanto, indispensável a qualquer companhia (art. 110) ${ }^{142}$. As ações preferenciais conferem vantagens em relação às ações ordinárias quando assim definidas pelo estatuto social, as quais podem consistir em prioridade na distribuição de dividendo, prioridade no reembolso de capital, entre outras, nos termos do art. 17. Na hipótese dessas ações terem o direito a voto excluído ou restringido pelo estatuto (art. 111), deverão ser observadas as disposições do art. $17, \S 1^{\circ}$ para que sejam admitidas à negociação no mercado de valores mobiliários, observada a limitação imposta pelo art. 15, §2 , a partir do ano de 2001.

As classes de ações previstas no art. $15, \S 1^{\circ}$ significam que as ações de uma mesma espécie podem ser divididas em grupos conforme os direitos e as vantagens atribuídos às ações. Com base no art. 16, as ações ordinárias podem ser classificas em função de sua conversibilidade em ações preferenciais, da exigência de nacionalidade brasileira do acionista ou do direito de voto em separado para o preenchimento de determinados cargos de órgãos administrativos. Da mesma forma, o art. 17 fornece alguns critérios para diferenciar em classes as ações preferenciais.

Lazzareschi, em anotação à obra de Mauro Penteado, alerta que "o fato de o aumento ser automático no regime de capital autorizado não significa que a companhia está autorizada a quebrar a proporcionalidade indicada no inciso I do art. 136 da Lei n. $6.404 / 7^{\prime \prime 143}$. A sinalização parece-nos importante, na medida em que, quando da emissão do bônus de subscrição, o conselho de administração ou a assembleia geral definem a espécie e a classe das ações a serem subscritas decorrentes do exercício do direito contido no título. Por essa razão, além de cumprir com esse requisito na emissão do bônus de subscrição, deverá o órgão competente guardar a proporcionalidade existente relativamente às ações preferenciais.

Assim, diante da diversidade de classificações que implicam em diferentes direitos e vantagens para os titulares de ações e a regra do art. 136, I, é imprescindível que a deliberação que determina a criação de bônus de subscrição indique a classe e a espécie de ação a que o bônus de subscrição dará direito.

\footnotetext{
${ }^{142}$ EIZIRIK, Nelson L. GAAL, Ariádna B., PARENTE, Flávia, HENRIQUES, Marcus de Freitas. Mercado de Capitais: Regime Jurídico, p. 61.

143 PENTEADO, Mauro. Aumentos de capital das Sociedades Anônimas, p. 152. Conforme Parecer CVM/SJU n. 66/83, é necessário que esteja estabelecido no estatuto desnecessidade de observar a proporcionalidade requerida no art. 136, I, da lei das sociedades anônimas, ainda que o aumento ocorra em regime de capital autorizado. No mesmo sentido, EIZIRIK, Nelson. A Lei das S/A Comentada, vol. II, p. 475: "A autorização para aumento de capital não implica em autorização para quebra de proporção. O aumento de classe existente sem guardar proporção com as demais deve ser sempre deliberado em assembléia geral extraordinária, salvo prévia e expressa previsão no estatuto nesse sentido".
} 
Além de definir a qualidade das ações resultantes do exercício do bônus de subscrição, é necessário determinar a sua quantidade, certificando-se que o capital autorizado da companhia é suficiente para atender à subscrição de ações ${ }^{144}$. Assim, na hipótese da companhia de capital autorizado chegar ao limite do capital autorizado, será necessária a realização de assembléia geral extraordinária para reformar o estatuto e estabelecer um novo limite de capital autorizado.

\subsubsection{Elementos facultativos do bônus de subscrição}

Dentre os elementos facultativos para emissão do bônus de subscrição, destacam-se a cláusula de ajustamento, a contratação de agente emissor e a emissão de certificado.

\subsubsection{Cláusula de ajustamento}

Não há exigência legal, porém usualmente fazem parte da prática da emissão de bônus de subscrição as cláusulas de ajustamento, as quais tem como finalidade salvaguardar os interesses dos proprietários de bônus de subscrição frente a operações posteriores, tais como outros aumentos de capital com subscrição de ações ou emissões de títulos que ocorram antes do exercício do bônus de subscrição.

Por meio deste tipo de cláusula, podem ser estipuladas regras para aumentar o número de ações a que o bônus de subscrição dá direito de subscrever em função de determinados eventos. Também pode ser definido que a realização de operações societárias especificadas dependerá de aprovação dos titulares de bônus de subscrição, à semelhança do que prevê o art. 231 quanto aos debenturistas. E, ainda, é possível que sejam estipulados critérios para alteração do preço de subscrição de novas ações caso sejam emitidas ações em valor inferior ao preço originalmente estabelecido.

Esse foi o ponto da discórdia entre a Companhia de Bebidas das Américas - Ambev e os titulares de bônus de subscrição que ensejou a consulta à Comissão de Valores Mobiliários e deu origem ao Processo CVM n SP2002/0474. Nesse caso, a deliberação que determinou a criação de bônus de subscrição continha cláusula de ajustamento que

144 Cf. GUERREIRO, José Alexandre Tavares. Regime Jurídico do Capital Autorizado, p. 130: "Caracterizada a subscrição como contrato, o exercício dos direitos conferidos pelo bônus de subscrição, assim como o exercício da opção de compra de ações pressupõem a disponibilidade de ações, por parte da companhia, para o cumprimento das obrigações respectivas” 
previa a equiparação do preço de subscrição das ações resultantes do exercício do bônus de subscrição ao valor de futuros "aumentos de capital por subscrição privada ou pública até o

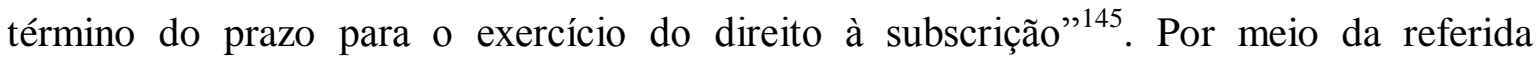
consulta, pretendia a companhia emissora a declaração da autarquia de que não era aplicável a cláusula de ajustamento. Os titulares dos bônus de subscrição, por sua vez, defendiam a sua incidência no exercício do título em questão.

Após manifestação dos interessados e da área técnica da Comissão de Valores Mobiliários, foi decidido que o "valor de subscrição do bônus da Ambev não deve ser ajustado pelo preço de exercício do bônus ocorrido em 1996 e nem mesmo pelo preço de exercício de opções de compra de ações decorrente de plano de outorga" ${ }^{„ 146}$. Assim, ficou decidido que a cláusula de ajustamento não poderia ser aplicada em relação ao preço de subscrição de ações. A análise mais detida sobre esse processo é realizada no Capítulo 5 que trata sobre a prática envolvendo o bônus de subscrição; a sua menção neste ponto tem somente o objetivo de exemplificar as conseqüências empíricas que podem advir da estipulação de cláusula de ajustamento.

Exemplificativamente, cabe referir que a cláusula de ajustamento pode prever também o impedimento de alterações societárias tais como cisão, fusão ou incorporação, até o encerramento do prazo de exercício do direito previsto nos bônus de subscrição ${ }^{147}$ ou, ainda, o exercício antecipado do título em decorrência eventos futuros especificados.

\subsubsection{Agente emissor}

Em virtude do que dispõe o parágrafo único do art. $78^{148}$, é aplicável aos bônus de subscrição o disposto nas Seções V a VII do Capítulo III que tratam sobre certificados, propriedade, circulação, constituição de direitos reais e outros ônus sobre as ações. Daí se conclui a necessidade da companhia manter livro de registro de bônus de subscrição ${ }^{149}$.

\footnotetext{
145 Cf. Ata da Assembleia Geral Extraordinária da Companhia de Bebidas das Américas - Ambev realizada em 2000 que reproduziu integralmente a ata de reunião do Conselho de Administração e do Conselho Fiscal da Companhia Cervejaria Brahma de 1996 que determinou a emissão de bônus de subscrição constante do Processo CVM No SP 2002/0474.

${ }^{146}$ Cf. Voto da Diretora Norma Jonssen Parente, relatora do Processo CVM No SP 2002/0474.

${ }^{147}$ CARVALHOSA, Modesto. Comentários à Lei de Sociedades Anônimas, vol. II, p. 66.

148 Art. 78. Os bônus de subscrição terão a forma nominativa.

Parágrafo único. Aplica-se aos bônus de subscrição, no que couber, o disposto nas Seções V a VII do Capítulo III.

${ }^{149}$ EIZIRIK, Nelson. A Lei das S/A Comentada, vol. I, p. 557-558.
} 
Porém, desejando a companhia transferir o ônus de manter a execução desta atividade internalizada, esta pode contratar a figura do "agente emissor" para realizar a escrituração e a guarda dos livros de registro e transferência do bônus de subscrição, que poderá ficar a cargo de instituição financeira autorizada pela Comissão de Valores Monetários (art. $27^{150}$ ), bem como de bolsas de valores (art. 293 $\left.{ }^{151}\right)^{152}$.

Em que pese a extinção das formas endossáveis e ao portador do bônus de subscrição após a edição da Lei n ${ }^{\circ}$ 9.457/1997, bem como da não utilização de certificados para operacionalizar o bônus de subscrição (assim como no caso de outros títulos), o agente emissor continua sendo uma alternativa indicada para que a companhia possa ganhar eficiência ao se concentrar somente na sua atividade negocial.

O agente emissor deve ser autorizado pela Comissão de Valores Mobiliários e, em linhas gerais, realiza as atividades de emissão de certificados, escrituração e guarda dos livros de registro e transferência de ações e bônus de subscrição, além dos demais títulos e valores mobiliários emitidos pela companhia (partes beneficiárias, debêntures). Não obstante, independentemente da contratação de agente emissor, a companhia é responsável pelos prejuízos causados decorrentes de vícios ou irregularidades verificadas em seus livros (art. 104), sendo a responsabilidade do agente emissor de natureza contratual perante a companhia e não em relação a terceiro ${ }^{153}$.

Essa é uma das vantagens da contratação do agente emissor, na medida em que permite separar as atividades de escrituração da propriedade e de transferências dos valores mobiliários em relação à obrigação de fiscalizar essas operações. Já que, quando concentradas em uma única pessoa, potencialmente é sacrificada a efetividade do controle sobre a regularidade da escrituração.

\subsubsection{Certificado de bônus de subscrição}

Conforme já referido anteriormente, a lei expõe, em seu art. 79, os elementos que devem constar no certificado do bônus de subscrição. Alguns deles já foram referidos

\footnotetext{
${ }^{150}$ Art. 27. A companhia pode contratar a escrituração e a guarda dos livros de registro e transferência de ações e a emissão dos certificados com instituição financeira autorizada pela Comissão de Valores Mobiliários a manter esse serviço.

$\$ 1^{\circ}$ Contratado o serviço, somente o agente emissor poderá praticar os atos relativos aos registros e emitir certificados. (...)

151 Art. 293. A Comissão de Valores Mobiliários autorizará as bolsas de valores a prestar os serviços previstos nos artigos 27; 34, $\S 2^{\circ}$; 39, $\S 1^{\circ} ; 40 ; 41 ; 42 ; 43 ; 44 ; 72 ; 102$ e 103.

${ }^{152}$ EIZIRIK, Nelson. A Lei das S/A Comentada, vol. I, p. 192.

${ }^{153}$ LOPES, Mauro Brandão, S.A.: Títulos e Contratos Novos, p. 13.
} 
quando tratamos sobre os requisitos essenciais do bônus de subscrição. Todavia, consoante já mencionado no item referente à caracterização do bônus de subscrição como título de crédito, a partir de 1997, com a Lei $\mathrm{n}^{\circ}$ 9.457, o bônus de subscrição passou a ter exclusivamente a forma nominativa. Por essa razão, não há mais a necessidade de emissão de um certificado.

Isso porque a comprovação da propriedade dos títulos nominativos, bem como a sua transferência, é feita através do competente registro nos livros da sociedade ou de escrituração por meio de instituição financeira especializada.

Assim, ao invés de imprimir um certificado, quando a companhia emite o bônus de subscrição, deverá registrar, no Livro de Registro de Bônus de Subscrição, a aquisição do título por cada investidor. Como salientado no item precedente, caso não tenha interesse em manter os registros sob sua responsabilidade, a companhia pode substituir o registro pela escrituração realizada por agente emissor, nos termos do art. 101.

Não obstante a forma nominativa prescindir da emissão de certificado, nem todos os elementos indicados pela lei se tornaram facultativos, devendo constar da deliberação do órgão competente: (i) o número, a espécie e a classe de ação a serem subscritas, (ii) o preço para a aquisição do bônus de subscrição ou a sua atribuição gratuita; (iii) o preço de emissão das ações ou os critérios para a determinação do preço; (iv) o prazo para exercício do direito de subscrição, o qual contempla a data de início e de término do período em que o titular poderá requerer a subscrição de ações a que o bônus de subscrição dá direito.

\subsection{Modalidades de emissão do bônus de subscrição}

O bônus de subscrição foi positivado pela lei das sociedades anônimas de modo a conter duas possibilidades de emissão, uma de forma autônoma e outra como vantagem adicional para investidores interessados na subscrição de ações da companhia ou na emissão de debêntures.

Importante salientar que, tanto em uma modalidade como na outra, a emissão dos bônus de subscrição não representa um efetivo aumento de capital, o qual somente ocorrerá quando exercido o direito incorporado no título ${ }^{154}$.

\footnotetext{
${ }^{154}$ MARTINS, Fran. Comentários à Lei das Sociedades Anônimas, p. 289.
} 


\subsubsection{Emissão para alienação a investidores}

O bônus de subscrição, como ferramenta para a capitalização da sociedade, intuitivamente conduz à noção de que sua emissão será sempre onerosa (art. 77, primeira parte). Nessa modalidade de emissão, quando houver distribuição pública de valores mobiliários, é obrigatória a atuação de instituição financeira como intermediadora entre a companhia e os investidores, auxiliando na definição da operação, do preço de emissão e assegurando ou não a colocação dos papeis no mercado, conforme a espécie de contrato de intermediação (underwriting) que for celebrado. O underwriting de valores mobiliários envolve as seguintes etapas: (i) estudo de viabilidade econômica da emissão pública analisando as condições do mercado para absorver os títulos a serem ofertados; (ii) montagem da operação com a determinação do volume de títulos, condições de liquidez do mercado; (iii) assessoria referente aos atos necessários para efetivar a emissão tais como a convocação e a realização de assembleia geral ou de reunião do conselho de administração, registros na Comissão de Valores Mobiliários, elaboração de prospecto e outros documentos distribuídos ao público; e após a realização dos atos preparatórios (iv) efetivar a colocação dos títulos mediante acompanhamento da cotação dos papéis em bolsa de valores, orientando a empresa quanto ao momento adequado para novos aumentos de capital $^{155}$.

Adicionalmente, cabe lembrar que partir da entrada no mercado de capitais, exigese que a companhia divulgue informações amplas e completas sobre si e sobre os valores mobiliários emitidos por ela. $\mathrm{O}$ objetivo das normas que regulamentam a abertura de capital e o instrumento para realizá-la (registro) é proteger os investidores através do fornecimento de informação que poderão melhor avaliar os riscos e o custo do seu investimento.

\subsubsection{Emissão para atribuição a subscritores de ações ou debêntures}

A segunda parte do art. 77 confere ao bônus de subscrição a função de incentivar a captação de recursos pela companhia por meio de "emissão de suas ações ou debêntures". No caso da atribuição do bônus de subscrição, o investidor deverá considerar, após

${ }^{155}$ EIZIRIK, Nelson. Aspectos Modernos do Direito Societário. Rio de Janeiro: Renovar, 1992, p. 28. 
subscrever as ações ou debêntures, se subscreverá as novas ações que correspondem ao bônus de subscrição no prazo estabelecido para o seu exercício ${ }^{156}$.

Quando atribuído pela companhia para facilitar a colocação de outros valores mobiliários, o bônus de subscrição é considerado gratuito, tendo em vista a redação do referido dispositivo legal que distingue a forma de emissão do bônus de subscrição: em uma hipótese há verbo "atribuir" que se opõe ao termo "alienar". Por essa razão, considerase essa modalidade de emissão como gratuita (e a emissão vinculada ao verbo "alienar", onerosa $)^{157}$. Se não fosse assim, possivelmente o bônus de subscrição atribuído perderia a sua conotação de incentivo.

Nesse particular, para a regularidade da atribuição gratuita é importante que esta resulte em vantagem para a companhia na captação de recursos ${ }^{158}$.

No caso do bônus de subscrição ser atribuído, o titular da debênture, por exemplo, "possuirá 2 (dois) direitos independentes e autônomos: o direito de crédito contra a companhia, decorrente da debênture; e o de subscrever ações de seu capital mediante o exercício dos direitos conferidos pelos bônus" ${ }^{159}$.

A utilidade para a companhia dessa modalidade de emissão de bônus de subscrição é a de que a atribuição desse título a ações ou debêntures aumenta a aceitação dos investidores em relação a esses valores mobiliários, na medida os adquirentes passam a contar com uma vantagem que confere valor adicional ao valor mobiliário com qual é ofertado $^{160}$.

\subsection{Da negociação e transferência do bônus de subscrição}

A propriedade do bônus de subscrição, por ser título nominativo, é garantida por meio de inscrição no livro da companhia emissora ou da instituição financeira responsável pela escrituração. Consequentemente, a transferência da propriedade opera-se por meio do registro no "Livro de Registro e Transferência de Bônus de Subscrição", por analogia ao

\footnotetext{
156 TEIXEIRA, Egberto Lacerda; GUERREIRO, José Alexandre Tavares. Das Sociedades Anônimas no Direito Brasileiro, p. 326.

${ }^{157}$ CINTRA, Maria Lúcia Borges de Araújo. Aspectos Jurídicos do Bônus de Subscrição, p. 74.

${ }^{158}$ EIZIRIK, Nelson. A Lei das S/A comentada, vol. I, p. 466

${ }^{159}$ EIZIRIK, Nelson. A Lei das S/A comentada, vol. I, p. 465.

${ }^{160}$ BOGEN, Jules I. Corporation Finance, p. 152: "Furthermore experience shows that a corporation can often induce security buyers to accept less attractive terms with a purchase warrant issue than a convertible one. This may be explained by the fact that the possession of a detachable warrant has the appearance of giving the buyer of the bond or the preferred stock a bonus which may have a substantial value apart from the security with which it is sold".
} 
disposto no art. 100, ou mediante lançamento na escrituração apropriada detida pela instituição depositária (art. 101) ${ }^{161}$.

Assim, a titularidade do bônus de subscrição não decorre da emissão ou da posse de certificado, mas da inscrição do nome do titular no Livro de Registro de Bônus de Subscrição ou no sistema da instituição depositária. A sua negociabilidade, portanto, deve atender aos requisitos de transferibilidade do registro ou escrituração.

Aplica-se aos bônus de subscrição a regra que veda a negociação, pela companhia, de suas próprias ações (art. 30), tendo em vista o que dispõe o art. 78, parágrafo único, e a lógica estabelecida pela lei de sociedades anônimas de evitar a manipulação de preço das ações e a distorção do processo de formação de preço do mercado de capitais ${ }^{162}$. A exceção fica por conta das hipóteses de cancelamento e manutenção em tesouraria, respeitado o limite de $10 \%$ por classe de ação em circulação. Ou seja, a companhia não pode negociar seus próprios bônus de subscrição, ressalva a permissão legal.

Com base no $\S 4^{\circ}$ do art. 30 da lei, enquanto permanecerem em tesouraria, os direitos pertencentes aos títulos ficarão suspensos, inviabilizando-se, desse modo, que a companhia subscreva suas próprias ações se sobrevier o prazo de exercício do bônus de subscrição enquanto em tesouraria. Por último, importante salientar a inaplicabilidade ao bônus de subscrição do art. $6^{\circ}$ da Instrução CVM n ${ }^{\circ} 10$, de $1980^{163}$ que veda a negociação do direito de subscrição decorrente do direito de preferência. Este dispositivo refere-se ao direito de preempção existente em relação à subscrição de ações, de modo que não pode ser confundido com o direito de subscrição incorporado pelo bônus de subscrição, pois nessa etapa não há mais direito de preferência (que somente existe quando da emissão do título).

Sobre a hipótese de aquisição pela companhia de bônus de subscrição de sua própria emissão, a Comissão de Valores Mobiliários já se pronunciou sobre essa questão,

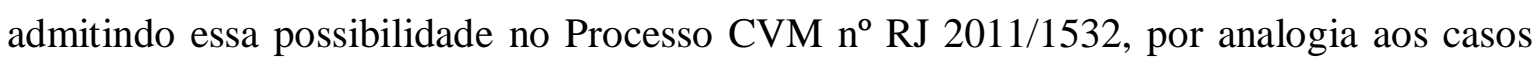
de negociação com as próprias ações (art. 30), desde que sejam respeitadas as limitações correspondentes $^{164}$.

\footnotetext{
${ }^{161}$ EIZIRIK, Nelson. A Lei das S/A Comentada, vol. I, p. 558.

${ }^{162}$ Art. $2^{\circ}$, inciso "c", da Instrução CVM n 10 , de 1980.

${ }^{163}$ Instrução CVM n ${ }^{\circ}$ 10, de 1980: Art. $6^{\circ}$ É vedado às companhias negociar com direitos de subscrição relativos às ações de sua própria emissão, ressalvada a hipótese de alienação em bolsa das sobras de ações não subscritas, prevista no art. 171, $\$ 7^{\circ}$, alínea " a" da Lei $n^{\circ} 6.404$, de 15 de dezembro de 1976.

${ }^{164}$ No Processo CVM no RJ 2011/1532, foi apresentada consulta sobre o regime aplicável à realização de oferta pública voluntária para aquisição da totalidade dos bônus de subscrição de sua própria emissão, incluindo aqueles sob titularidade do acionista controlador. No voto vencedor, a diretora Luciana Dias
} 
O Processo CVM no RJ 2011/1532 foi iniciado por consulta formulada pela companhia sobre a viabilidade da realização de oferta pública para aquisição de bônus de subscrição de ações de sua própria emissão. Especificamente nesse caso, a sociedade requereu o pronunciamento da Comissão de Valores Mobiliários a respeito da possibilidade (i) da oferta pública ser estendida a todos os detentores de bônus de subscrição da companhia indistintamente, inclusive ao acionista controlador; e (ii) da companhia realizar a oferta pública com o pagamento do valor econômico dos bônus de subscrição com eventual prêmio sobre seu valor de mercado.

A autarquia decidiu pela admissibilidade de estender a oferta pública pretendida pela companhia a todos os detentores de bônus de subscrição indistintamente, inclusive ao seu acionista controlador, e por valor superior ao de mercado desde que justificado pela administração da sociedade.

\subsection{Direito de preferência}

O direito de preferência consiste em um direito essencial dos acionistas (art. 109, IV) que lhes garante a possibilidade de manter a sua participação no capital social quando da subscrição de ações para aumento de capital (art. 171). Considerando que não é apenas nessa situação que a proporção acionária pode ser alterada, o $\$ 3^{\circ}$ do mesmo dispositivo garante o direito de preferência também em relação às "emissões de debêntures conversíveis em ações, bônus de subscrição e partes beneficiárias conversíveis em ações emitidas para alienação onerosa". Assim, em regra, quando a companhia promove medida capaz de alterar a correlação das posições acionárias, abre-se a possibilidade dos acionistas adquirirem os mencionados títulos, na proporção de ações que já possuem, a fim de conservar os direitos patrimoniais e políticos decorrentes da titularidade desses valores mobiliários.

Nesse aspecto, é esclarecedora a identificação da natureza potestativa do direito de preferência, considerando que este confere ao seu titular a prerrogativa de atuar unilateralmente sobre a esfera jurídica alheia ${ }^{165}$. A justificativa para que a lei acolha essa proteção está no fato de que a emissão pela companhia de novos títulos poderá significar a perda da posição acionária que confere determinado padrão de dividendos, a possibilidade

entendeu ser possível a operação desde que atendidos os requisitos estabelecidos pelo art. 30 da Lei n. ${ }^{\circ}$ 6.404/76 e adotando-se as salvaguardas inspiradas na Instrução CVM nº 361, de 2002.

${ }^{165}$ COMPARATO, Fábio Konder. Novos Ensaios e Pareceres de Direito Empresarial, p. 177. 
de propor ação de reparação (art. 246, §1 1 , “a”), requerer a exibição de livros da companhia (art. 105) ou a instalação de conselho fiscal (art. 277), entre outros, considerando que essas medidas estão condicionadas à titularidade de parcela mínima do capital social.

A Lei das Sociedades Anônimas (art. 171, $3^{\circ}$, prima pars ${ }^{166}$ ) assegura aos acionistas a preferência na subscrição da emissão de bônus de subscrição (bem como de debêntures conversíveis em ações e de partes beneficiárias conversíveis em ações) emitidos para alienação onerosa. Ela também admite a exclusão do direito de preferência para a companhia aberta que pretende proceder ao aumento de capital via bônus de subscrição quando sua emissão se der por meio de (i) venda em bolsa de valores ou subscrição pública ou de (ii) permuta de ações em oferta pública de aquisição de controle. Em relação à companhia fechada, a lei afastou a possibilidade de exclusão do direito de preferência, exceto no caso de lei especial sobre incentivo fiscal (art. 172, caput e parágrafo único ${ }^{167}$ ).

Quanto ao momento do exercício do bônus de subscrição, a lei já prevê a exclusão do direito de preferência quando se tratar de companhia sob o regime de capital autorizado (art. 171, $\S 3^{\text {o168 }}$ ), desnecessária, portanto, a previsão estatutária nesse sentido ${ }^{169}$. A segunda parte do $\S 3^{\circ}$ do art. 171 é explícita ao referir que quando da "conversão" dos títulos em ações não haverá direito de preferência. A solução definida pela lei é coerente com o instituto do direito de preferência e eficiente do ponto de vista da operacionalização dos valores mobiliários. Não fosse assim, poderia ocorrer o absurdo de que, com o exercício da

\footnotetext{
${ }^{166}$ Art. 171 (...) $\$ 3^{\circ}$ Os acionistas terão direito de preferência para subscrição das emissões de debêntures conversíveis em ações, bônus de subscrição e partes beneficiárias conversíveis em ações emitidas para alienação onerosa; mas na conversão desses títulos em ações, ou na outorga e no exercício de opção de compra de ações, não haverá direito de preferência.

167 Art. 172. O estatuto da companhia aberta que contiver autorização para o aumento do capital pode prever a emissão, sem direito de preferência para os antigos acionistas, ou com redução do prazo de que trata o $\$ 4^{\circ}$ do art. 171, de ações e debêntures conversíveis em ações, ou bônus de subscrição, cuja colocação seja feita mediante:

I - venda em bolsa de valores ou subscrição pública; ou

II - permuta por ações, em oferta pública de aquisição de controle, nos termos dos arts. 257 e 263.

Parágrafo único. O estatuto da companhia, ainda que fechada, pode excluir o direito de preferência para subscrição de ações nos termos de lei especial sobre incentivos fiscais.

168 Art. 171. Na proporção do número de ações que possuírem, os acionistas terão preferência para a subscrição do aumento de capital. (...)

$\S 3^{\circ}$ Os acionistas terão direito de preferência para subscrição das emissões de debêntures conversíveis em ações, bônus de subscrição e partes beneficiárias conversíveis em ações emitidas para alienação onerosa; mas na conversão desses títulos em ações, ou na outorga e no exercício de opção de compra de ações, não haverá direito de preferência.

${ }^{169}$ GUERREIRO, José Alexandre Tavares. Regime Jurídico do Capital Autorizado, p. 116: "Exclusiva do regime analisado é, segundo se verificou no n. 18, a possibilidade de exclusão estatutária do direito preferencial de subscrição desde que a sociedade revista, concomitantemente, a condição de companhia aberta, de acordo com a definição do art. $4^{\circ}$ da Lei n. 6.404. Fora do regime de capital autorizado, inexiste a exclusão do direito de preferência em nosso direito, com a exceção, apenas, da hipótese de subscrição de ações nos termos de lei especial sobre incentivos fiscais (art. 172, parágrafo único)”.
} 
preempção no momento da subscrição de ações, os antigos acionistas pudessem "retirar" dos titulares de bônus de subscrição o direito de justamente subscrever essas ações. Logo, para manter o sentido do direito de preferência e a adequação do sistema, o direito de preferência somente poderá ser exercido quando da emissão do bônus de subscrição.

Relativamente ao direito de preempção na emissão de bônus de subscrição por atribuição como vantagem adicional a doutrina diverge acerca da aplicação do art. 171, $\S 3^{\circ}$. De acordo com Maria Lúcia Cintra, o direito de preferência nesse caso deverá seguir o direito de preferência da ação ou debênture cuja colocação é auxiliada pelo bônus de subscrição, "pois não existem duas preferências, a dos acionistas sobre ações ou debêntures a que vêm anexados e sobre os próprios bônus" ${ }^{\text {"170 }}$.

Em sentido contrário, Mauro Brandão Lopes entende que a exclusão do direito de preferência não é possível em relação ao bônus de subscrição atribuído gratuitamente, por entender que a restrição do $\S 3^{\circ}$ do art. 171 se aplica somente a partes beneficiárias conversíveis em ações. Justifica sua posição com base na redação do dispositivo que possui declinação feminina na frase "emitidas para alienação onerosa" e no fato de que as debêntures conversíveis em ações não existem na modalidade gratuita, motivo pelo qual a expressão não teria sentido se englobasse os três títulos mencionados (debêntures conversíveis em ações, bônus de subscrição e partes beneficiárias conversíveis em ações), devendo limitar-se, portanto, às partes beneficiárias ${ }^{171}$.

Com o mesmo entendimento, posiciona-se Eizirik sustentando que o direito de preferência compreende tanto o bônus de subscrição para alienação onerosa como aquele atribuído como vantagem adicional por entender que a restrição refere-se apenas às partes beneficiárias conversíveis em ações ${ }^{172}$.

Essa nos parece a posição mais acertada, considerando a finalidade do direito de preferência em proteger os acionistas contra a perda de posição acionária, especialmente em razão de que o direito potestativo em questão preclui diante do não exercício e libera as

\footnotetext{
${ }^{170}$ CINTRA, Maria Lúcia Borges de Araújo, Aspectos Jurídicos do Bônus de Subscrição, pp. 166-167.

171 Além disso, segundo o autor, "não se deve sequer considerar a possibilidade de se tratar de lapso na redação do dispositivo ou na sua impressão oficial: é razoável a exclusão do direito de preferência na subscrição de partes beneficiárias conversíveis em ações, para atribuição gratuita a pessoas que à companhia prestaram serviços, mas o mesmo não se pode dizer dos bônus de subscrição, que constituem já agravamento injustificável do direito de preferência dos acionistas, de modo que criar bônus, por deliberação majoritária e sem direito de recesso, para atribuição graciosa sem preferência dos acionistas, é tornar inoperante o princípio geral do art. 171. LOPES, Mauro Brandão, S.A.: Títulos e Contratos Novos, p. 82-83.

${ }^{172}$ EIZIRIK, Nelson. A Lei das S/A comentada, vol. I, p. 466: "A referência à expressão "emitidas para alienação onerosa", constante da primeira parte do $\S 3^{\circ}$ do artigo 171 , aplica-se somente às partes beneficiárias conversíveis em ações, pois, caso abrangesse os bônus, a regra contida naquele artigo seria inócua"
} 
ações e debêntures para subscrição e aquisição, respectivamente, em conjunto com o bônus de subscrição atribuído. Ou seja, além dos convincentes argumentos apresentados em favor do direito de preferência em relação à emissão gratuita do bônus de subscrição, acrescentamos que o reconhecimento em favor destes não é prejudicial à companhia que terá cumprido o seu objetivo de capitalizar-se, independentemente do investidor ser o antigo acionista ou terceiro interessado.

Por fim, é importante salientar que o prazo para exercício do direito de preferência deve ser fixado pelo órgão responsável pela emissão do bônus de subscrição, não se sujeitando as companhias abertas de capital autorizado ao prazo mínimo de 30 dias (art. 171, $4^{\circ}$ ) em virtude do que estabelece o art. 172.

Por fim, é importante a reflexão de que o direito de preferência em relação ao bônus de subscrição acarreta um ônus maior aos acionistas que desejarem manter sua posição, na medida em que, além de pagar o preço das ações no prazo do exercício, deverão também pagar o preço de emissão do bônus de subscrição, o qual não existiria em um aumento de capital por simples subscrição de ações. Para Carvalhosa, significa pagar por um direito que já possuem ${ }^{173}$.

Considerando, todavia, que a subscrição de ações somente ocorrerá caso o preço de subscrição das ações seja inferior ao de mercado, essa "onerosidade" adicional do direito de preferência é mitigada pelo fato do antigo acionista poder subscrever ações em patamares mais favoráveis do que um aumento de capital por subscrição de ações em condições normais (não decorrentes do exercício do bônus de subscrição). Além disso, a situação é prevista e autorizada por lei, de modo que não poderá, com base nisso, ser questionada pelos acionistas, desde que executada de acordo com os parâmetros legais do direito de preferência.

\subsection{Diluição Injustificada}

Para que a companhia realize o aumento de capital mediante subscrição de novas ações, deverá respeitar a vedação legal de diluição injustificada, a qual se encontra positivada no $\S 1^{\circ}$ do art. 170 . A norma tem como objetivo resguardar os acionistas que não subscrevem ações em aumento de capital por força do exercício do direito de preferência. Isso porque, com o aumento de capital e a subscrição de novas as ações, o número total de

${ }^{173}$ CARVALHOSA, Modesto. Comentários à lei de sociedades anônimas, vol. 2, p. 84. 
ações (em que se divide o capital social) aumenta e o número de ações do acionista que não acompanha a subscrição se mantém igual. Logo, ele passa a uma posição proporcionalmente inferior à original em relação ao total de ações ${ }^{174}$.

A diluição, além de significar uma redução no valor que as mesmas ações representam, pode implicar também na redução de direitos patrimoniais como a diminuição do montante recebido a título de dividendos e a perda do exercício de alguns direitos políticos quando condicionados a um determinado percentual do capital social, como, por exemplo, o pedido de informações ao conselho fiscal (art. 163, §6 $6^{\circ}$ ou de exibição de livros (art. 105).

Ocorre, portanto, a diluição quando o aumento do número de ações altera a fração do lucro ou do patrimônio líquido a que corresponde cada ação, considerando que o valor do lucro total ou do patrimônio líquido não acompanha a ampliação do número de ações na mesma proporção ${ }^{175}$. Não obstante, a diluição somente é vedada pela lei acionária quando não atende a uma razão que a fundamente, ou seja, quando o aumento do número de ações ou da cifra de capital não é pautado no interesse da companhia ou na efetiva necessidade de aumentar o capital social.

Assim, na diluição em exame, concorrem dois interesses igualmente válidos: de um lado o da companhia cujo influxo de recursos mediante aumento de capital é positivo e necessário para a realização de sua atividade, da qual se beneficiará também o acionista ${ }^{176}$, e, de outro, o interesse do acionista em manter sua posição acionária sem o aporte de novos recursos ou quando não é possível exercer o direito de preferência.

$\mathrm{Na}$ tentativa de equilibrar o interesse da companhia e o dos acionistas, a lei estabeleceu os critérios já apresentados no item 2.2.2.4 para determinação do preço de subscrição das ações a que o bônus de subscrição dá direito.

Assim, na determinação do valor do aumento de capital e do número de ações que serão emitidas e do preço de subscrição das novas ações, compete à companhia justificar a

\footnotetext{
${ }^{174}$ EIZIRIK, Nelson. A Lei das S/A Comentada, vol. II, p. 496: “os acionistas que não acompanharem o aumento de capital terão sua participação no patrimônio da companhia injustificadamente diluída na proporção do preço que favoreceu os subscritores. Assim, pode-se dizer que ocorre uma transferência indireta do valor aos acionistas atuais não subscritores para os que subscreveram o aumento de capital".

${ }^{175}$ EIZIRIK, Nelson. A Lei das S/A Comentada, vol. II, p. 503.

${ }^{176}$ Nesse sentido, é esclarecedor a colocação de ROSMAN, Luiz Alberto Colonna, Modificação do capital social, In: LAMY FILHO, Alfredo; PEDREIRA, José Luiz Bulhões (coord.). Direito das Companhias, p. 1.383: "a subscrição de novas ações aumenta o estoque de recursos próprios da sociedade, mas daí não se infira que todo aumento de capital social é, por definição, do interesse da companhia, pois o fim da sociedade comercial não é acumular recursos próprios, mas auferir lucro em benefício dos acionistas; a realização desse fim é medida pela quantidade de lucro por unidade de patrimônio líquido, e o excesso de recursos (em relação às necessidades da empresa) não é neutro do ponto de vista do interesse social, pois reduz a taxa de rentabilidade do patrimônio líquido da sociedade e, consequentemente, do investimento dos acionistas".
} 
modificação da participação acionária em função da necessidade da obtenção de recursos sob a forma de aumento de capital e também em relação ao valor determinado para a subscrição das novas ações sob pena de responsabilidade dos acionistas controladores e administradores. Se bem sucedida nessa tarefa, a companhia estará diante da hipótese de diluição justificada.

\subsection{Restrições à circulação de ações da companhia}

A livre circulação de ações é da essência das sociedades anônimas, motivo pelo qual a cessibilidade desse valor mobiliário deve predominar com base no princípio da autonomia da vontade, de modo que seja possível aos acionistas dispor de suas ações independentemente da concordância da companhia ou de outros acionistas ${ }^{177}$. A lei das sociedades anônimas, contudo, admite a restrição estatutária a esse direito para as companhias fechadas, desde que (i) minuciosamente regulada, (ii) não impeça a negociação das ações e (iii) não sujeite o acionista ao arbítrio dos órgãos de administração da companhia ou da maioria dos acionistas (art. 36).

A exceção fica por conta da chamada golden share prevista no art. $17, \S 7^{\circ}$ que é o nome usado para a "ação preferencial de classe especial, de propriedade exclusiva do ente desestatizante, à qual o estatuto social poderá conferir os poderes que especificar”.

Regras que imponham a restrição à circulação de ações de sua propriedade por meio de acordo de acionistas, mesmo em companhia aberta, não são obstados pelo conteúdo do art. 36, na medida em que a norma tem como fundamento impedir que a companhia interfira na negociabilidade das ações ${ }^{178}$. O dispositivo, portanto, não impede que o acionista decida fazê-lo em relação a suas próprias ações com base nos seus próprios interesses.

Considerando a possibilidade de restrição estatutária da circulação de ações e o conteúdo do bônus de subscrição (direito de subscrever ações), Guerreiro apresenta interessante questionamento a respeito da possibilidade de aplicação do art. 36 em relação

177 TEIXEIRA, Egberto Lacerda; GUERREIRO, José Alexandre Tavares. Das Sociedades Anônimas no Direito Brasileiro, p. 236.

${ }^{178}$ LOBO, Carlos Augusto da Silveira. In: LAMY FILHO, Alfredo; PEDREIRA, José Luiz Bulhões (coord.). Direito das Companhias. Rio de Janeiro: Forense, 2009, p. 465-466: "Outros, a nosso ver, com melhores razões, entendem que o artigo 36 da LSA veda a exclusão da negociabilidade das ações nos estatutos sociais porque é disposição incompatível com uma característica essencial do tipo societário, não podendo, por isso, constituir norma geral interna da organização da companhia. Entretanto, esse preceito legal, dirigido ao estatuto, não pode aplicar-se a contratos entre acionistas, que tem por objeto disposição de bens de seus patrimônios individuais (as ações), sem interferir na organização da companhia ou no contato social". 
ao bônus de subscrição. Segundo o autor, é incompatível a incidência do mencionado artigo com a natureza de título de crédito do bônus de subscrição, cuja literalidade seria afetada por uma medida restritiva da companhia ${ }^{179}$.

Não obstante o abalizado posicionamento, entendemos que para ser respeitada a literalidade do título não é necessário que bônus de subscrição contenha negociabilidade irrestrita. O requisito da literalidade exige que o conteúdo, a extensão e as modalidades do direito incorporados no título estejam expressos. Assim, a inserção de limites à cessibilidade do bônus de subscrição efetivada pela companhia não retira a sua natureza de título de crédito.

E, considerando que o bônus de subscrição não atribui uma titularidade sobre posição acionária, mas tão somente um direito de adquirir uma participação, não incide sobre ele a disciplina abarcada pelo princípio da livre cessibilidade de ações inerente às sociedades anônimas. A garantia mínima de circulação aplicável às ações não é indispensável ao bônus de subscrição, na medida em que se fosse determinada a impossibilidade de negociação do título, essa estipulação não ofenderia o fundamento antes referido intrínseco às sociedades anônimas.

Ademais, se os titulares de bônus de subscrição decidirem acordar a restrição da negociabilidade dos títulos, também não verificamos óbice legal para obstar o exercício da autonomia da vontade destes titulares.

Assim, eventual vedação à negociação de bônus de subscrição não impede a entrada de terceiros ou a saída de acionistas da companhia, não sendo aplicável a esse título, portanto, a proibição do art. 36 que inviabiliza o estatuto social obstar de modo absoluto a circulação de ações ${ }^{180}$.

\footnotetext{
${ }^{179}$ GUERREIRO, José Alexandre Tavares. Regime Jurídico do Capital Autorizado, p. 120.

${ }^{180}$ CORRÊA-LIMA, Osmar Brina. Sociedade Anônima. 2 ed., Belo Horizonte: Del Rey, 2003, p. 150.
} 


\section{CAPÍTULO 3 - EXERCÍCIO DO BÔNUS DE SUBSCRIÇÃO}

Conforme descrito nos capítulos precedentes, a emissão do bônus de subscrição ocorre quando o órgão competente da companhia delibera a sua criação e o distribui a investidores, de forma privada ou pública. Identificados os requisitos e elementos que compõem a emissão, a negociação e a transferência do bônus de subscrição, faz-se necessário explorar a etapa seguinte, que corresponde à escolha sobre exercer ou não o direito de subscrever as ações da companhia que emitiu o título. Na data ou no período estabelecido para o exercício do bônus de subscrição, o titular possui, portanto, duas possibilidades, cuja escolha, por uma ou por outra, depende unicamente da sua vontade, não tendo a companhia qualquer ingerência sobre essa decisão ${ }^{181}$.

Dentre as opões que dispõe, o titular pode deixar passar em branco o prazo do exercício, abstendo-se simplesmente de praticar os atos que denotam a escolha por subscrever ações da companhia. Nessa hipótese, transcorrido o tempo para o exercício do bônus de subscrição, decai o titular do direito de subscrever ações e o título é extinto ${ }^{182}$.

Não exercendo o direito de subscrever ações, a parcela do capital autorizado reservada para a subscrição atinente ao bônus de subscrição será liberada, podendo a companhia utilizá-la para outra finalidade ${ }^{183}$.

Alternativamente, cabe ao titular, nos termos do parágrafo único do art. 75, exercer o bônus de subscrição, mediante "apresentação do título à companhia". Como já referimos no item 1.2.3. do Capítulo 2, em virtude da revogação das modalidades endossáveis e ao portador do bônus de subscrição e outros valores mobiliários, na prática, não há mais a emissão de certificado físico que possa ser "apresentado" à companhia.

Assim, caberá ao titular do bônus de subscrição manifestar sua vontade de exercitar o direito de subscrição mediante a sua identificação como titular, que deverá corresponder àquela constante no Livro de Registro de Bônus de Subscrição ou na conta específica na

\footnotetext{
${ }^{181}$ A lei de sociedades anônimas não prevê a hipótese do direito conferido pelo bônus de subscrição ser restringido ou suspenso por determinação da companhia. Contudo, consoante apresentado no Capítulo 5 que aborda a utilização na prática societária do título, não é incomum que companhias fechadas emitam o bônus de subscrição com cláusulas suspensiva, condicionando o exercício do bônus de subscrição ao cumprimento de determinadas metas operacionais ou financeiras, por exemplo.

${ }^{182}$ A hipótese de extinção consta no item 8.16.1 do Regulamento da BM\&FBOVESPA que prevê a exclusão automática do bônus de subscrição admitido a negociação pela Bolsa, se na data correspondente não for exercitado o direito de subscrição de ações.

${ }^{183}$ CARVALHOSA, Modesto. Comentários à lei de sociedades anônimas, vol. 2, p. 70.
} 
instituição depositária correspondente, conforme tiver optado a companhia pela forma registrada ou escritural do título ${ }^{184}$.

Em regra, a decisão acerca do exercício do direito de subscrição conferido pelo bônus de subscrição é motivada pela valorização do preço das ações no mercado em relação ao preço de subscrição definido quando da emissão do título (havendo suficiente volume de negociação para gerar uma opinião representativa de integrantes do mercado ${ }^{185}$ ), assim como pelos aspectos relacionados à rentabilidade da companhia e à liquidez e volatilidade de suas ações.

No caso da companhia fechada, os fundamentos para a escolha de se tornar acionista mediante a subscrição de novas ações difere quanto à forma de se identificar a racionalidade econômica do investimento, já que não há cotação das ações na bolsa ou no mercado de balcão. A verificação a respeito do desempenho da companhia pode partir de critérios como patrimônio líquido e rentabilidade ou até mesmo índices de produtividade, ou outras formas de identificar a valorização da sociedade, tais como capex (capital expenditure) ou opex (operational expenditure).

Optando-se pelo exercício do bônus de subscrição, caberá à companhia sujeitar-se à decisão do titular, a qual implicará para a sociedade a prática dos atos aos quais se obrigou quando da emissão do título, quais sejam, proceder ao aumento de capital, a subscrição de ações e o seu registro no livro correspondente. Em caso de ações escriturais, deverá determinar a respectiva escrituração pela instituição financeira contratada.

\section{Aumento de capital mediante subscrição de ações}

Quando da subscrição de ações decorrentes do exercício do bônus de subscrição, a lei de sociedades anônimas prevê especificamente o aumento de capital (art. 166, III). Dentre as possibilidades previstas no art. 166, o inciso III é a única hipótese que prevê o aumento de capital sem que seja necessária deliberação dos órgãos da companhia, considerando que tal medida já foi tomada anteriormente, quando da deliberação que determinou a emissão do título. Logo, é desnecessária nova providência nesse sentido, seja assemblear ou por parte do conselho de administração ${ }^{186}$.

\footnotetext{
${ }^{184}$ LAMY FILHO, Alfredo; PEDREIRA, José Luiz Bulhões (coord.). Direito das Companhias, p. 656. ${ }^{185}$ ROSMAN, Luiz Alberto Colonna, Modificação do capital social, p. 1.418.

${ }^{186}$ LOPES, Mauro Brandão, S.A.: Títulos e Contratos Novos, p. 88: "Mas nenhuma deliberação é necessária, seja de assembléia, seja do Conselho, quando se trata de converter em ações partes beneficiárias ou
} 
Isso porque a existência de bônus de subscrição pressupõe a vigência do regime de capital autorizado e a partir do exame conjunto dos artigos 166 e 168, resta claro que o aumento de capital nessas condições não importa em reforma do estatuto social. Tal reforma já foi realizada quando o mencionado regime foi autorizado no estatuto social da companhia $^{187}$.

Não havendo deliberação pelos órgãos da companhia para operacionalizar o aumento de capital resultante do exercício do bônus de subscrição, ocorre, na realidade, uma "operação financeira, representada pelo ingresso de recursos de terceiros, que são convertidos em capital próprio da companhia" ${ }^{188}$.

No regime de capital autorizado, antes do exercício do bônus de subscrição, o capital social da companhia compreende o montante fixado no estatuto social e o valor potencial decorrente da autorização para aumento de capital. É essa potencialidade que é preenchida, total ou parcialmente, pela emissão de novas ações subscritas por força do exercício do bônus de subscrição.

Enquanto vigorar o regime do capital autorizado, a companhia é envolvida por uma dicotomia em relação ao capital social, a qual é usual no sistema das corporations norteamericanas. Essa dicotomia é representada, de um lado, pelo capital autorizado, composto por authorized shares, ou dito de outro modo, stated capital. De outro lado, há o capital emitido ou subscrito (issued capital) ${ }^{189}$. Assim, o aumento de capital modificará o montante de issued capital, porém não será alterado o valor do capital social "total" declarado no estatuto social.

Por esse motivo é que se diz que, quando do exercício do bônus de subscrição, ocorre tão somente a correspondente operação contábil que registra o ingresso de capital na companhia. Não obstante, o aumento de capital decorrente da opção exercida pelo titular do bônus de subscrição, ainda que sujeito a capital autorizado, deve ser averbado na junta comercial correspondente, por força do disposto no art. $166, \S 1^{\circ 190}$.

debêntures, ou de exercer direitos conferidos por bônus de subscrição ou opções de compra (n. III). Isso porque a deliberação de assembléia, ou do Conselho, terá sido anteriormente tomada, ao se decidir sobre a emissão de partes beneficiárias conversíveis em ações, de debêntures conversíveis em ações, e de bônus de subscrição, bem como sobre a outorga de opções de compra de ações"

${ }^{187}$ PENTEADO, Mauro Rodrigues. Aumentos de Capital das Sociedades Anônimas, p. 149.

${ }^{188}$ CARVALHOSA, Modesto. Comentários à lei de sociedades anônimas, vol. 2, p. 69.

${ }^{189}$ GUERREIRO, José Alexandre Tavares. Regime Juridico do Capital Autorizado, p. 50.

190 EIZIRIK, Nelson. A Lei das S/A Comentada, vol. II, p. 47: "Na hipótese do inciso III, o aumento é averbado na Junta Comercial, independentemente de deliberação do conselho de administração ou da assembléia geral, já que é automático, pois decorre do exercício de direitos dos titulares de valores mobiliários. 
Quanto à subscrição das ações objeto do bônus de subscrição, é necessário que se determine no que consiste essa subscrição, tendo em vista também a relevância deste aspecto para definir o remédio jurídico adequado em caso de inadimplemento da companhia da obrigação de subscrever ações em decorrência do exercício do bônus de subscrição. Assim, no presente ponto, caberá delinear os contornos da subscrição de ações e deixar para o item 3 deste capítulo a análise detida sobre os aspectos processuais e a tutela jurisdicional aplicável ao descumprimento da obrigação da companhia.

De acordo com Maria Lúcia Cintra, a subscrição de ações corresponde a "contrato bilateral e de adesão, pelo qual uma das partes - a sociedade - oferece a outra - o subscritor - uma emissão de capital representado por ações e a outra parte aceitando a oferta e pagando a quantia exigida, adquire a qualidade de acionista"191 . Para a autora, a relação jurídica pode ser decomposta em oferta (emissão do bônus de subscrição) e aceitação (apresentação do título à companhia e o pagamento do preço de subscrição) ${ }^{192}$.

No mesmo sentido, se posiciona Rosman, para quem a vontade da companhia é expressa pela deliberação da assembleia geral que aprova o aumento de capital, porém não basta para a emissão de ações. Para ele, "é proposta de contrato, cujo objeto é criar novas posições jurídicas de acionistas; os subscritores das ações aceitam essa proposta assinando o boletim de subscrição e pagando o valor mínimo estipulado na oferta"193. Consequentemente, o negócio é concluído ao se completar a subscrição de toda a emissão oferecida pela companhia, ou da parcela mínima estipulada na oferta (efetivando-se o aumento do capital).

Também se fundamentando na noção de subscrição como contrato, Bulhões Pedreira e Lamy Filho afirmam que o exercício do direito incorporado pelo bônus de subscrição se verifica mediante o pagamento do preço de subscrição das ações pelo titular, não sendo necessária a celebração formal do contrato de subscrição, completando-se este com pagamento ${ }^{194}$. À companhia competiria, tão somente, cumprir sua obrigação

${ }^{191}$ CINTRA, Maria Lúcia Borges de Araújo. Aspectos Jurídicos do Bônus de Subscrição, p. 189.

${ }^{192}$ No mesmo sentido, o direito norte-americano retrata a subscrição como a conjunção da oferta com sua aceitação: "In the case of subscrition for stock after a corporation has been formed and is in existence, the subscriber becomes a stockholder simply by mutual assent. No formal contract is required. (...) There must simply be an offer and an acceptance, as in the case of any other contract", cf. BALLANTINE, Henry Winthrop. Ballantine on Corporations, Chicago: Gallaghan and Company, 1927, p. 107.

${ }^{193}$ ROSMAN, Luiz Alberto Colonna, Modificação do capital social, p. 1.397

${ }^{194}$ LAMY FILHO, Alfredo; PEDREIRA, José Luiz Bulhões (coord.). Direito das Companhias, p. 657: “com o exercício do direito e o pagamento do preço de emissão das ações completa-se o contrato de subscrição subjacente à emissão do título, independentemente de qualquer manifestação de vontade da companhia ou formalidade; a companhia tem a obrigação de inscrever a propriedade do adquirente da ação no 'Livro de Registro de Ações Nominativas' ou instruir a instituição financeira depositária das ações a efetuar o 
correspondente ao direito exercido de registrar a propriedade de novas ações no 'Livro de Registro de Ações Nominativas' ou, no caso de ações escriturais, de requerer à instituição financeira responsável a realização da escrituração correspondente.

Aprofundando a análise sobre a subscrição de ações como modalidade de contrato, Guerreiro salienta a existência de cláusula potestativa em favor do investidor, ao qual cumpre decidir sobre o exercício do bônus de subscrição que lhe permitirá subscrever ações, sem que a sujeição decorrente do exercício de direitos potestativos implique em invalidação da "contratualidade da subscrição, uma vez que esses direitos potestativos só se adquirem pelos respectivos titulares em face de ofertas efetuadas pela companhia, às quais se vincula, resultando o contrato da aceitação dos oblatos, aos quais compete, efetivamente, verdadeira potestas no sentido de concluí-lo"195.

Trilhando o mesmo caminho dos juristas citados, Carvalhosa detalha que para a efetivação do aumento de capital desencadeado pelo exercício do bônus de subscrição, é necessária a celebração do contrato de subscrição que se aperfeiçoa com a declaração de vontade pertinente ao negócio jurídico da subscrição, a assinatura do boletim e o pagamento da totalidade ou parte do valor da subscrição ${ }^{196}$. Eizirik apresenta a mesma configuração de proposta e aceitação entre companhia e investidor do bônus de subscrição e, no tocante à oferta, descreve-a como "declaração unilateral e irretratável de vontade, pela qual uma pessoa obriga-se a fazer parte da sociedade, quer a constituição da companhia ocorra por subscrição pública, quer por subscrição particular"197.

Em sentido divergente, Mauro Brandão Lopes entende que o exercício dá ensejo à conversão do título em ações e não um direito de subscrição ${ }^{198}$. Não concordamos com

\footnotetext{
lançamento da aquisição da ação, se escritural; e o adquirente da ação terá o direito de exigir que a companhia cumpra essa obrigação".

${ }^{195}$ GUERREIRO, José Alexandre Tavares. Regime Juridico do Capital Autorizado, p. 129.

196 CARVALHOSA, Modesto. Comentários à lei de sociedades anônimas, vol. 2, p. 70-71: "O contrato de subscrição precede às medidas necessárias à efetivação do aumento. Tendo sido tal aumento predeterminado, a parte do capital autorizado a ele destinada será destacada para o cumprimento da obrigação, não podendo a companhia dispor de tal parcela para outro fim. E, consoante o regime de capital autorizado, o aumento respectivo será automático, bastando o seu arquivamento no Registro do Comércio. (...) O contrato aperfeiçoa-se com a assinatura e o pagamento da primeira parcela ou da totalidade do valor de subscrição. A partir daí, torna-se acionista da companhia, com os respectivos direito e a correspondente obrigação de integralizar o valor subscrito (art. 106 e s)"

${ }^{197}$ EIZIRIK, Nelson. A Lei das S/A Comentada, vol. I, p. 509. No mesmo sentido, Pontes de Miranda quando discorreu sobre a constituição da sociedade por ações, conceituou a subscrição como o ato pelo qual o subscritor se vincula para adquirir ações da sociedade, cf. MIRANDA, Pontes de. Tratado de Direito Privado, t. 50, atualizado por Alfredo de Assim Gonçalves Neto, São Paulo: Editora Revista dos Tribunais, 2012, pp. 184-185.

${ }^{198}$ LOPES, Mauro Brandão. S.A.: Títulos e Contratos Novos, p. 85: "O bônus de subscrição, na verdade, confere o direito de imediata conversão em ações mediante o pagamento de seu preço de emissão, e não propriamente o direito de subscrever ações no desenrolar de processo normal de aumento de capital"
} 
essa concepção na medida em que conversão é "a passagem, que se atribui aos títulos de uma classe a outra" ${ }^{, 199}$, modalidade aplicável às debêntures conversíveis e às partes beneficiárias. Nesses casos, o valor do crédito (pago à companhia quando da aquisição das debêntures e da partes beneficiárias) já integra o patrimônio da sociedade, motivo pelo qual no aumento de capital este é apenas "convertido" o para capital social e corresponde ao pagamento pela subscrição de ações, nos termos da escritura de emissão ou do estatuto social $^{200}$.

Em ambas as hipóteses, portanto, o titular - quando da aquisição das debêntures ou parte beneficiárias - efetua o aporte que servirá de pagamento para as ações que lhe serão subscritas (se assim optar) ${ }^{201}$. O mesmo não se dá em relação ao bônus de subscrição, cujo montante pago na emissão não representa nem o preço, nem adiantamento, total ou parcial, do valor fixado para subscrever ações. Este deve ser pago apenas quando o titular decidir exercer o direito de subscrição.

Assim, entendemos que quando o investidor manifesta sua vontade de subscrever ações da companhia, está aceitando a oferta contida no título. Logo, para que haja subscrição de ações, é necessário que (i) a companhia realize uma oferta de suas ações representada pela emissão do bônus de subscrição; (ii) que investidores interessados aceitem a proposta da companhia; (iii) concluam o contrato mediante assinatura do boletim; e (iv) pagamento do preço estabelecido, evento que sujeitará a companhia ao registro ou escrituração do contratante como acionista.

Importante lembrar que, mesmo sujeito ao regime de capital autorizado, a companhia deve cumprir a exigência legal de realização mínima de 3/4 do capital social (art. 170) antes de promover um aumento de capital. A regra visa dar maior flexibilidade à companhia para capitalizar-se mediante subscrição de ações, quando seu capital ainda não está totalmente integralizado por conta de acionistas remissos ${ }^{202}$.

\footnotetext{
${ }^{199}$ MIRANDA, Pontes de. Tratado de Direito Privado, t. 50, p. 582. Nesse mesmo sentido, CARY, William L.; EISENBERG, Melvin Aron. Cases and Materials on Corporations, p. 1144: "Conversion is the act of exchanging one class of security for another, the conversion right being created by written contract between the holder of the security and the company which issued it".

${ }^{200}$ TOMAZETTE, Marlon. Direito Societário, p. 248.

${ }^{201}$ GUIMARÃES, Francisco José Pinheiro. Debêntures. In: LAMY FILHO, Alfredo; PEDREIRA, José Luiz Bulhões (coord.). Direito das Companhias. vol. 1, Rio de Janeiro, Forense, 2009, p. 595: “A cláusula da conversibilidade assegura ao titular da debênture a opção por substituir o seu investimento em título da dívida por ações da companhia emissora. O exercício dessa opção assegura ao debenturista: (a) aumento de rendimento, quando há previsão de que os dividendos a serem distribuídos às ações serão superiores aos juros das debêntures, ou (b) ganho de capital, quando o custo de aquisição das ações, resultantes das bases de conversão, é inferior ao valor de mercado das ações."

${ }^{202}$ EIZIRIK, Nelson. A Lei das S/A Comentada, vol. II, p. 493.
} 


\section{Modalidades de pagamento do preço de subscrição}

Nesse tópico, serão examinadas as modalidades de pagamento do preço do bônus de subscrição, dentre as quais estão o pagamento em dinheiro e o pagamento mediante compensação de créditos contra a companhia ${ }^{203}$.

Para Carvalhosa, a subscrição pode ser feita em dinheiro ou por aproveitamento de créditos líquidos do titular do bônus, junto à companhia ${ }^{204}$. Eizirik admite o pagamento da subscrição de ações em bens ou dinheiro em aumento de capital em companhia de capital autorizado $^{205}$. A segunda hipótese, pagamento em dinheiro, prevalece na prática, em virtude das formalidades necessárias para que ocorra o pagamento em bens, que demanda deliberação da assembléia geral para determinar a avaliação dos mesmos (art. 122, VI) ${ }^{206}$.

O pagamento por meio de bens suscetíveis de avaliação pecuniária, admitido para compor o capital social $\left(\operatorname{art.} 7^{\circ}\right.$ ), é legalmente possível também na hipótese de aumento de capital por exercício do bônus de subscrição. Nesse caso, "os bens devem estar relacionados com a atividade da companhia ou apresentar uma utilidade efetiva"207 para a empresa, já que o capital social funciona como garantia dos credores. Desse modo, a sua aceitação pela companhia deve ser compatível com o interesse social, além de economicamente viável.

Além destes requisitos, para que bens possam compor o capital social, é necessária a realização de sua avaliação por três peritos nomeados por meio de assembleia geral, convocada e instalada nos termos do art. $8^{\circ}$. Apenas após a aceitação pelo subscritor do valor atribuído pela avaliação é que os bens serão incorporados ao patrimônio da companhia.

\footnotetext{
${ }^{203}$ CINTRA, Maria Lúcia Borges de Araújo. Aspectos Jurídicos do Bônus de Subscrição, p. 182.

${ }^{204}$ CARVALHOSA, Modesto. Comentários à lei de sociedades anônimas, vol. 2, p. 69.

${ }^{205}$ EIZIRIK, Nelson. A Lei das S/A Comentada, vol. II, p. 476.

${ }^{206}$ Mesmo que o conselho de administração possua competência para aprovar aumento de capital por delegação da assembleia geral, quando o aumento ocorrer em bens, ainda depende-se da assembleia geral aprovar a avaliação, ato privativo nos termos do art. 122, VI, cf. BORBA, José Edwaldo Tavares. Direito Societário, p. 455. No mesmo sentido, PENTEADO, Mauro Rodrigues. Aumentos de Capital das Sociedades Anônimas, p. 327: "O aumento de capital mediante subscrição de novas ações visa à obtenção de valores pecuniários ou não pecuniários para a companhia, da mesma natureza daqueles que a lei prevê para formação do capital, a saber: contribuições em dinheiro ou qualquer espécie de bens suscetíveis de avaliação em dinheiro $\left(\operatorname{art.} 7^{\circ}\right.$ ) inclusive os bens intangíveis, direito de crédito contra terceiro (respondendo aquele pela solvência do devedor - art. 10), vedada a integralização em serviços, conforme §2". Para COSTA, Philomeno J. da. Anotações às Companhias, vol. I, São Paulo: Revista dos Tribunais, p. 149, é possível a subscrição de ações em bens que não tem relação com o objeto da sociedade, desde que tenha valor de mercado. Entretanto, é necessário lembrar que essa prática constitui uma modalidade de abuso de poder do acionista controlador, no termos do art. $117, \S 1^{\circ}$, "h".
}

${ }^{207}$ EIZIRIK, Nelson. A Lei das S/A Comentada, vol. I, p. 100. 
Considerando as regras de implementação do aumento de capital mediante integralização em bens acima resumidas, entendemos que, na prática, esta modalidade é operacionalmente incompatível com a sistemática dos bônus de subscrição cuja emissão e exercício são desenhados para conferir agilidade e efetividade ao processo de aumento de capital.

A modalidade de pagamento mediante integralização em bens, portanto, abrange procedimento difícil de conciliar com a dinâmica da subscrição com bens, na medida em que demandam perícia e realização de assembleia geral. Consequentemente, a admissão, pela companhia, deste procedimento mostra-se pouco conveniente. Por essa razão, há sociedades anônimas cujo estatuto social admite apenas a subscrição em dinheiro.

\section{Inadimplemento pela companhia: execução específica de obrigação de fazer}

Conforme definido no Capítulo 2, o bônus de subscrição consiste em um negócio jurídico, onde o investidor adquire um título da companhia mediante o pagamento do seu preço. O título confere ao investidor o direito de subscrever ações no prazo e condições estabelecidas. O exercício do bônus de subscrição compreende a manifestação de vontade do seu titular no sentido de subscrever novas ações da companhia e o pagamento do preço estabelecido, concluindo-se, desse modo, o contrato ofertado pela companhia ${ }^{208}$.

Da conclusão do contrato de subscrição nasce, para a companhia, a obrigação perante o titular, de subscrever as ações mediante aumento de capital com o respectivo registro ou escrituração das ações em nome do investidor. Trata-se de autêntica obrigação de fazer ${ }^{209}$ que a doutrina classifica como obrigação de conduta, a qual "não tem por objeto uma coisa, mas um ato e implica para uma pessoa o dever de prestar esse ato ou de absterse dele". ${ }^{210}$ Mais especificamente, as obrigações de fazer ensejam o "direito aos resultados esperados das condutas devidas, não às condutas em si mesmas, embora ordinariamente esses resultados sejam produzidos pelas condutas devidas" ${ }^{\text {211. }}$.

\footnotetext{
${ }^{208}$ EIZIRIK, Nelson. Temas de Direito Societário, pp. 466-467.

209 BEVILÁQUA, Clóvis. Direito das Obrigações, 2. ed., Bahia: Livraria Magalhães, 1910, p. 82: “As obrigações de fazer [...] muitas vezes consistirão num ato ou fato para cuja execução se não exige um desenvolvimento de força física ou intelectual. Quando alguém promete prestar uma fiança, o exemplo é de Savigny, a essência do ato objeto da obrigação, não consiste no insignificante dispêndio de esforço que a prestação da fiança possa exigir, mas sim na necessidade de concluir a operação jurídica a que se vem ligar, de um lado, os riscos, e de outro, as vantagens do crédito fornecido".

${ }^{210}$ DINAMARCO, Cândido Rangel. Fundamentos do processo civil moderno, t. 1, p. 983.

${ }^{211}$ DINAMARCO, Cândido Rangel. Fundamentos do processo civil moderno, t. 1, p. 984.
} 
No caso, a obrigação da companhia de subscrever suas ações possui caráter infungível e materialmente possível, de modo que as ações de outra companhia ou valores mobiliários diversos da ação não satisfazem a pretensão do investidor, considerando que a ação comporta não apenas atributos econômicos, mas também reflete uma posição acionária dentro de uma sociedade, a qual não pode ser substituída ou compensada pela posição acionária em outra companhia ${ }^{212}$. Se a emissão de bônus de subscrição estiver inserida em um quadro complexo como uma operação societária de ajustamento de controle, torna-se ainda mais imprescindível que o titular disponha de uma alternativa para a recusa da companhia em satisfazer sua pretensão.

Assim, na eventualidade da companhia descumprir a obrigação que lhe cabe ${ }^{213}$, a ordem processual brasileira permite que a parte prejudicada pela resistência da parte obrigada alcance a tutela jurisdicional por meio de execução específica, modalidade processual que permite ao titular do bônus de subscrição buscar a satisfação da obrigação, podendo escolher a via judicial ou a arbitragem ${ }^{214}$.

Antes da Lei $\mathrm{n}^{\circ}$ 8.952/1994, preponderava o entendimento de que o cumprimento de obrigações de fazer não podia ser coercitivamente exigido, motivo pelo qual, não havendo o adimplemento voluntário, cabia à parte prejudicada a demanda meramente indenizatória $^{215}$. A importância da execução específica em nosso ordenamento é indiscutível, na medida em que, tratando-se de obrigação de fazer não cumprida, a indenização em dinheiro não satisfaz necessariamente a pretensão do credor prejudicado.

Nesse ponto é que a definição de subscrição de ações apresentada no item anterior mostra-se indispensável. Com base na concepção delineada, é possível identificar o conteúdo do provimento judicial (ou do procedimento arbitral, conforme o caso) que deve ser perseguido pelo titular do bônus de subscrição. Isso porque se considerarmos que, no

${ }^{212}$ GUERREIRO, José Alexandre Tavares. Execução específica do acordo de acionistas. In: Revista de Direito Mercantil, n. 41, ano XX (nova série), São Paulo: Revista dos Tribunais, jan./mar.,1981, p. 51: “A razão de ser da execução específica em ajustes da espécie prende-se à necessidade de satisfazer o interesse contrariado pelo inadimplemento, de sorte a colocar parte inocente exatamente na mesma posição jurídica e econômica que teria se a parte faltosa houvesse cumprido voluntariamente o acordo. Pressupões-se, na hipótese, a ineficácia das reparações equivalentes e compensatórias (perdas e danos)".

${ }^{213}$ GUERREIRO, José Alexandre Tavares. Execução específica do acordo de acionistas. In: Revista de Direito Mercantil, n. 41, ano XX (nova série), São Paulo: Revista dos Tribunais, jan./mar., 1981, p. 42: O inadimplemento é bem delineado como "a resistência à pretensão do titular do interesse não satisfeito"

${ }^{214}$ CARMONA, Carlos Alberto. Arbitragem e Processo: Um Comentário à Lei n. 9.307/96, 2 ed., rev., atual. e ampl., São Paulo: Atlas, 2004, p. 55-56. A arbitragem como meio alternativo de solução de controvérsia por meio de um árbitro ou conjunto de 3 árbitros escolhidos pelas partes. São requisitos para arbitragem a capacidade dos contratantes para firmar a convenção de arbitragem e a controvérsia abranger direitos patrimoniais disponíveis, ou seja, sobre os quais a lei admite transação.

${ }_{215}$ ALVIM, Arruda; ASSIS, Araken de; ALVIM, Eduardo Arruda. Comentários ao Código de Processo Civil. Rio de Janeiro: GZ Editora, 2012, p. 640. 
inadimplemento em questão, deixou a companhia de emitir declaração de vontade pertinente ao contrato de subscrição, a solução para a resistência da companhia será diferente da hipótese em que o descumprimento se referir à efetivação do registro do novo titular no livro correspondente.

De acordo com nossas conclusões no item 1 deste capítulo, a subscrição de ações no caso em estudo consiste em um contrato envolvendo uma oferta por parte da companhia quando da emissão do bônus de subscrição e uma aceitação por parte do titular, no momento em que este exerce o direito conferido pelo título. Por isso, cumpre à companhia sujeitar-se ao direito potestativo exercido mediante a execução da obrigação de fazer que lhe compete, não sendo possível cogitar, na hipótese em análise, que faltaria à conclusão do contrato, declaração de vontade da companhia.

Assim, quando o titular do bônus de subscrição não se torna titular das ações a que tem direito por resistência da companhia, a verdadeira satisfação do seu direito somente ocorrerá por meio de uma sentença para compelir a companhia a subscrever as ações e registrar o requerente como acionista. Esse é o entendimento também de Carvalhosa que salienta ser insatisfatória a compensação por perdas e danos em relação ao descumprimento, por parte da companhia, de sua obrigação de contratar a subscrição de ações com o titular do bônus de subscrição que decide exercer o seu direito ${ }^{216}$.

Assim, no caso do bônus de subscrição, seu titular demandará provimento judicial que determine à companhia que registre o número de ações correspondentes em seu nome ou, no caso de ações escriturais, que imponha à instituição financeira a correspondente escrituração.

Consequentemente, não são aplicáveis à espécie os artigos 466-A e 466-B do Código de Processo Civil que tratam da execução específica em virtude de omissão da parte adversa em emitir declaração de vontade ou concluir contrato. A tutela relacionada a esses dispositivos permite que a sentença judicial ou arbitral substitua a vontade do contratante faltoso e produza os efeitos da declaração não emitida ou a eficácia do contrato que deixou de ser firmado.

Diferentemente, no caso do bônus de subscrição, já foi concluído o contrato com o exercício do direito de subscrição, não cabendo à companhia emitir declaração de vontade no sentido de "aceitar" subscrever as ações decorrentes do exercício do bônus de subscrição: a companhia já está vinculada pela oferta contida no bônus de subscrição.

${ }^{216}$ CARVALHOSA, Modesto. Comentários à lei de sociedades anônimas, vol. 2, p. 71. 
Caracterizada a lide no caso concreto, cumpre ao titular do bônus de subscrição buscar a composição do impasse gerado pela inatividade da companhia por meio da execução específica de obrigação de fazer. A demanda a ser proposta encontra fundamento nos artigos $461^{217}$ e $644^{218}$ do Código de Processo Civil, já que, nesse caso, a satisfação do direito do titular ocorre apenas com o registro ou escrituração das ações ${ }^{219}$.

A tutela jurídica abrigada nesses dispositivos permite que o credor da obrigação obtenha comando sentencial determinando à companhia devedora que execute a conduta inadimplida. Em caráter liminar ou ao cabo do procedimento, cabe ao poder judicante aplicar multa $\left(\operatorname{art} .461, \S^{\circ}\right.$ ) para coagir a sociedade ré a tomar a providência determinada na hipótese desta seguir sem cumprimento ${ }^{220}$.

A astreinte ou multa é uma pena pecuniária decorrente do descumprimento, a qual tem como função coagir o devedor a executar a obrigação de fazer que lhe foi ordenada, revertendo em benefício do autor. A multa não tem natureza indenizatória ou punitiva ${ }^{221}$, de forma que, se não for cumprida a determinação judicial, a parte prejudicada tem direito à multa, ainda que haja posterior conversão em perdas e danos ${ }^{222}$. O caráter da multa é coercitivo e, por essa razão seu valor não é limitado pelo valor da obrigação ${ }^{223}$.

O reiterado descumprimento da determinação judicial na tutela específica, a despeito da aplicação de multa, pode ensejar a majoração do valor da astreinte e a sua execução nos próprios autos do processo ${ }^{224}$. Não havendo pagamento espontâneo da multa, cabe execução por quantia certa contra devedor solvente.

São requisitos da execução específica aqueles aplicáveis a outros procedimentos de cognição: (i) a propositura da demanda por partes legitimadas pela lei processual, (i) a possibilidade jurídica do pedido e (iii) o interesse processual. Quanto ao primeiro requisito, são legitimados para figurar na demanda ora analisada o titular do bônus de subscrição na

${ }^{217} \mathrm{CPC}$, Art. 461. Na ação que tenha por objeto o cumprimento de obrigação de fazer ou não fazer, o juiz concederá a tutela específica da obrigação ou, se procedente o pedido, determinará providências que assegurem o resultado prático equivalente ao do adimplemento.

${ }^{218}$ CPC, Art. 644. A sentença relativa a obrigação de fazer ou não fazer cumpre-se de acordo com o art. 461, observando-se, subsidiariamente, o disposto neste Capítulo.

${ }^{219}$ MIRANDA, Pontes de. Comentários ao Código de Processo Civil, t. 5, 3. ed., ver., e aum., atualização legislativa de Sergio Bermudes, Rio de Janeiro: Forense, 1997, p. 76: “A norma do art. 461 assegura ao credor a própria prestação objeto da obrigação, tal como ocorreria no caso do voluntário e perfeito cumprimento dela"

${ }^{220}$ MIRANDA, Pontes de. Comentários ao Código de Processo Civil, t. 5, p. 78.

${ }^{221}$ SILVA, João Paulo Hecker da. Processo Societário: Tutelas de Urgência e da Evidência. Brasília: Gazeta Jurídica, 2014, p. 106-107: "Tal entendimento esbarra na própria finalidade da aplicação da multa, já que pressupor seu caráter indenizatório, na verdade, inviabilizaria o cumprimento da própria execução específica

${ }_{222}^{22}$ MIRANDA, Pontes de. Comentários ao Código de Processo Civil, t. 10, 2. ed., 2002, p. 116-117.

223 ALVIM, Arruda; ASSIS, Araken de; ALVIM, Eduardo Arruda. Comentários ao Código de Processo Civil, p. 641.

${ }^{224}$ SILVA, João Paulo Hecker da. Processo Societário: Tutelas de Urgência e da Evidência, p. 112. 
qualidade de autor e, como parte ré, a companhia emissora do bônus de subscrição que deixou de subscrever as ações em nome do investidor.

O pedido juridicamente possível corresponde a requerimento para que as obrigações decorrentes do contrato de subscrição celebrado entre as partes sejam cumpridas mediante a realização do registro ou escrituração de ações e a assinatura do respectivo boletim pelo investidor. No último caso, quando o pedido envolver a escrituração das ações por instituição financeira contratada pela companhia, aquela não será parte do processo, ante a ausência de relação jurídica com os titulares de bônus de subscrição, devendo apenas ao final do processo ser intimada para dar cumprimento à eventual sentença de procedência.

A pretensão do titular do bônus de subscrição não se destina a substituir, portanto, a vontade dos acionistas em deliberar um aumento de capital, mas tão somente a cumprir a obrigação de registrar as ações em nome do titular. Na execução específica aplicável ao caso, não se pretende obter uma sentença que interfira na formação da vontade social, mas que determine o cumprimento da obrigação decorrente da aceitação, pelo titular do bônus de subscrição, da oferta irrevogável de subscrição de ações.

No tocante ao interesse processual ${ }^{225}$, cabe dizer que esse requisito se desdobra em dois elementos: utilidade e necessidade. O primeiro diz respeito à existência de prejuízo experimentado pelo interessado que justifique a tutela jurídica. E o elemento da necessidade significa que a demanda judicial deve ser o único meio legítimo para obter a satisfação do direito. Isto é, faltará interesse de agir em uma ação que demandar efeitos condenatórios, por exemplo, quando o autor já possuir título executivo apto a exigir a tutela jurisdicional por meio de ação de execução, pois falta interesse ao autor para obter uma sentença condenatória.

Diante da aquisição de bônus de subscrição, a solução que corresponde, completa e adequadamente, ao investimento realizado é a conversão do titular em acionista da sociedade emissora, medida que, não tomada espontaneamente pela companhia, dependerá da coercitividade do provimento judicial ou arbitral. Desse modo, é inafastável o interesse processual do titular do bônus de subscrição na execução específica.

Por outro lado, não caberá a propositura da demanda por investidor que não pagou o valor correspondente à subscrição das ações a que tem direito, sob pena de incorrer na

${ }^{225}$ Cf. CHIOVENDA, Giuseppe. Instituições de direito processual civil. vol. 1. $2^{\mathrm{a}}$ ed. Campinas: Bookseller, 2000. p. 226: "o interesse de agir consiste nisto, que sem a intervenção dos órgãos jurisdicionais, o autor sofreria um dano injusto". 
exceção ao contrato não cumprido (art. 476 do Código Civil), idêntica à vedação imposta pelo art. 466-C ${ }^{226}$ do Código de Processo Civil. Assim, é requisito para a propositura de execução específica o pagamento do montante previsto para subscrição das ações realizado diretamente à companhia ou, se esta não o receber, mediante depósito judicial, nos termos do art. 334 e seguintes do Código Civil.

Tratando-se de obrigação que deve ser executada por terceiro, como ocorre quando a escrituração de ações da companhia deve ser feita por instituição financeira, o comando sentencial deverá condenar a companhia, porém determinará a expedição de mandado de intimação à instituição financeira para adimplir a prestação.

Outrossim, a execução específica em exame, não se refere à hipótese adjudicação compulsória, pois o objeto da execução específica não se refere a uma coisa, mas à obrigação de fazer de responsabilidade da companhia. A adjudicação compulsória tem aplicação na transferência de propriedade envolvendo promessa de contrato de compra e venda de bens imóveis sem cláusula de arrependimento (art. 1.417 e 1.418 do Código Civil).

Por fim, devemos tratar sobre a eficácia da sentença proferida no processo de tutela específica. Antes do processo civil admitir as tutelas específicas, as sentenças eram classificadas simplesmente em declaratória, constitutiva e condenatória - categorias cujo procedimento admitia pouca flexibilidade em termos de espécie de provimentos que podiam ser oferecidos para tutelar o direito do demandante. Não se aceita mais apenas a compensação em dinheiro do autor que teve seu direito violado para operar a reparação do dano. Atualmente o direito processual é aparelhado de instrumentos que permitem ao órgão jurisdicional constranger o demandado pela cominação de multa ou determinar a realização do direito postulado a terceiro.

Consequentemente, a sentença relacionada à aplicação de multa recebeu a classificação de mandamental e o provimento que utiliza meios de execução direta é qualificado como executiva $^{227}$. Esses são os provimentos que visam oferecer ao autor a tutela específica de seu direito, não se limitando a reparar a situação jurídica desvantajosa pela compensação em dinheiro.

\footnotetext{
226 Art. 466-C. Tratando-se de contrato que tenha por objeto a transferência da propriedade de coisa determinada, ou de outro direito, a ação não será acolhida se a parte que a intentou não cumprir a sua prestação, nem a oferecer, nos casos e formas legais, salvo se ainda não exigível.

${ }^{227}$ MARINONI, Luiz Guilherme; ARENDHART, Sérgio Cruz. Curso de Processo Civil. vol. 2, 11 ed., rev. e atual, São Paulo: Revista dos Tribunais, 2013, p. 416.
} 
Tem caráter mandamental ${ }^{228}$, portanto, a sentença que determina a subscrição de ações decorrentes do exercício do bônus de subscrição. Não há efeito constitutivo como no caso da sentença proferida por força da execução específica dos artigos 466-A e 466-B do Código de Processo Civil já referidos, mas autêntica ordem de cumprimento. A sentença com eficácia mandamental difere daquela com eficácia executiva, porquanto esta, por força de lei, permite medidas de satisfação imediata do credor, como ocorre, por exemplo, na ação de despejo, nas ações possessórias e de desapropriação. Nas sentenças de cunho mandamental, o juiz poderá somente pressionar o devedor para cumprir a condenação ${ }^{229}$. Assim, não há eficácia executiva na sentença requerida pelo titular de bônus de subscrição, na medida em que no provimento executivo há a realização do próprio ato pretendido pelo autor $^{230}$.

Há divergência ${ }^{231}$ entre os processualistas sobre a classificação da ação como mandamental, porém o que importa para a finalidade deste estudo são os efeitos que esta pode produzir sobre a esfera jurídica da companhia demandada por descumprimento de obrigação decorrente de contrato de subscrição concluído com titular de bônus de subscrição.

A propósito do tema, vale mencionar que no $§ 5^{\circ}$ do art. 461 do Código de Processo Civil, há rol exemplificativo ${ }^{232}$ de comandos que o juízo pode lançar mão para forçar o cumprimento da obrigação. Em casos extremos de recalcitrância do devedor em adimpli-la, a doutrina admite, no âmbito da tutela específica, até a possibilidade de intervenção judicial na sociedade ${ }^{233}$. No presente caso, parece-nos que a intervenção para fins de

\footnotetext{
${ }^{228}$ DINAMARCO, Cândido Rangel. Instituições de Direito Processual Civil, vol. II, São Paulo: Malheiros, 2001, pp. 242-243. De acordo com o autor, a sentença de eficácia mandamental é uma espécie de sentença condenatória e a explica como "título para a execução forçada, tanto quanto a condenação ordinária - e portanto é também uma condenação. A diferença está no conteúdo da sanção imposta em seu segundo momento, na qual se exacerba o fator comando, ou mandamento. Na ordem jurídica brasileira, tem esse teor as sentenças concessivas de mandado de segurança e as que condenam por obrigação de fazer ou de nãofazer, seja no sistema do Código de Processo Civil (art. 461), seja do Código de Defesa do Consumidor (art. 84)."

${ }^{229}$ MARINONI, Luiz Guilherme; ARENDHART, Sérgio Cruz. Curso de Processo Civil, vol. 2, p. 426: "A sentença mandamental é caracterizada por dirigir uma ordem para coagir o réu. Seu escopo é convencer o réu a observar o direito por ela declarado. Portanto, não é mandamental a sentença que exige que seja expedido mandado para que um terceiro a registre. Se o oficial do registro civil é obrigado a registrar uma sentença que desconstitui a relação jurídica existente entre as partes, tal sentença é desconstitutiva, e não mandamental.

${ }^{230}$ DINAMARCO, Cândido Rangel. Instituições de Direito Processual Civil, vol. II, pp. 245-246.

${ }^{231}$ Para Marques, há apenas as eficácias declaratória, condenatória e constitutiva, admitindo a lei que o juiz utilize de algum poder discricionário para dar efetividade ao comando legal, cf. MARQUES, José Frederico. Instituições de Direito Processual Civil. vol. I, Campinas: Millennium, 2000, p. 481.

${ }^{232}$ MIRANDA, Pontes de. Comentários ao Código de Processo Civil, t. 5, p. 79.

${ }^{233}$ PUOLI, José Carlos Baptista. Os Poderes do Juiz, a Tutela Processual Específica e o Direito Societário. In: YARSHELL, Flávio Luiz; PEREIRA, Guilherme Setoguti J (Coords.). Processo Societário, São Paulo: Quartier Latin, 2012, p. 413.
} 
subscrição de ações constitui medida desproporcional e inadequada para desafiar o princípio da mínima interferência, de modo que a astreinte é a opção mais acertada para incentivar o adimplemento.

Ademais, a sentença proferida na ação que busca a condenação do réu a cumprir obrigação de fazer não é terminativa, pois não extingue o processo, apenas acolhe o pedido, na medida em que caberá, na sequência, a execução da medida imposta à parte inadimplente $^{234}$. Na hipótese em que a aplicação de multa não resulte no cumprimento da sentença que condena a companhia a subscrever as ações, restará apenas a conversão da condenação em perdas e danos, a qual poderá ser requerida nos autos do processo.

Outra possibilidade cabível para o titular do bônus de subscrição que exerce o direito de subscrever ações e não as recebe é a propositura de ação de reparação por perdas e danos ${ }^{235}$ (ao invés de demandar por tutela específica). Nesse caso, entendemos que caberia o ressarcimento do valor pago a título de subscrição das ações e eventuais distribuição de dividendos, caso tenha havido deliberação social nesse sentido, bem como outros benefícios percebidos pelos acionistas da mesma espécie e classe de ações a que tinha direito o titular do bônus de subscrição.

${ }^{234}$ MARINONI, Luiz Guilherme; ARENDHART, Sérgio Cruz. Curso de Processo Civil, vol. 2, p. 404.

${ }^{235}$ ALVIM, Arruda; ASSIS, Araken de; ALVIM, Eduardo Arruda. Comentários ao Código de Processo Civil, p. 640: "No sistema atual, a obrigação de fazer, assim como a de não fazer, somente se converterá em obrigação de indenizar, caso se torne impossível o cumprimento da obrigação ou caso opte o credor por esse caminho." 


\section{CAPÍTULO 4 - INSTITUTOS AFINS AO BÔNUS DE SUBSCRIÇÃO}

Neste capítulo, será feita a análise de institutos que, por sua finalidade, características ou regime jurídico, se aproximam do bônus de subscrição. A comparação da opção de compra de ações, das debêntures conversíveis em ações e da opção de compra de ações negociada na bolsa de valores permite a melhor compreensão do objeto do estudo, na medida em que possibilita confrontar os elementos do bônus de subscrição que não se destacam na sua análise isolada.

Por meio deste método, objetivamos aprofundar o estudo do bônus de subscrição pondo a descoberto o que Ascarelli chamou de "premissas implícitas" ao discorrer sobre o estudo do direito comparado ${ }^{236}$. Assim, por meio da confrontação das características comuns e díspares de institutos afins ao bônus de subscrição, entendemos que podemos enriquecer a análise do nosso objeto de estudo.

\section{Opção de compra de ações outorgada a empregados, administradores e prestadores de serviço à companhia}

O primeiro instituto a ser comparado com o bônus de subscrição é a opção de compra de ações outorgada a administradores, empregados ou prestadores de serviços (art. $\left.168, \S 3^{\circ}\right)$, cuja regulamentação no direito norte-americano é realizada pelo mesmo dispositivo que trata do stock purchase warrant ( $\$ 157$ do Delaware Code e $\$ 6.24$ do Model Business Corporation Act).

No direito brasileiro, a nomenclatura da opção de compra de ação, conforme se posicionou a doutrina ${ }^{237}$, é inadequada para denominar a relação jurídica abrangida pelo

\footnotetext{
${ }^{236}$ ASCARELLI, Tullio. Problemas das Sociedades Anônimas e Direito Comparado, p. 12-13: "Esta obra é, com frequiência, árdua, porque, ao contrário do que se pensa, as doutrinas nacionais omitem, às vezes, a indicação de características que, no entanto, são dos mais importantes nos diversos direitos. A omissão é fácil, porque, tratando-se, quase sempre de elementos muito familiares aos leitores nacionais, pode parecer implícito o seu conhecimento. Mas o estudioso de direito comparado encontra, às vezes, a chave da explicação, justamente nos elementos silenciados pela doutrina nacional do direito que ele escolheu para objeto do seu exame. É, por isso, que, através do direito comparado, somos frequentemente levados a investigar o que chamarei de 'premissas implícitas' (econômicas, sociais, doutrinárias, etc.) nos diversos direitos, premissas às vezes não formuladas, e, no entanto, de importância para evidenciar o alcance das soluções jurídicas, bem como para explicar a diretriz da evolução de determinado direito".

${ }^{237}$ ARAGÃO, Paulo Cezar. Opções de Compra de Ações e Bônus de Subscrição, p. 63. EIZIRIK, Nelson. A Lei das S/A Comentada, vol. II, p. 478. GUERREIRO, José Alexandre Tavares Guerreiro. Sobre opção de compra de ações. In: Revista de Direito Mercantil, Industrial, Econômico e Financeiro. São Paulo: Revista dos Tribunais, v. 39, jul./set., 1980, p. 226-227.
} 
instituto. Isso porque o direito por ele incorporado não é o de "compra" de ações, mas de subscrição.

Esse entendimento se confirma com base na lei, tendo em vista que esta expressamente afastou o direito de preferência na outorga e no exercício da opção de compra de ações (art. 171, $\S 3^{\circ}$ ). Se a opção conferisse um direito de compra propriamente dito, segundo esclarece Guerreiro, não teria qualquer sentido a lei explicitar a exclusão do direito de preferência de algo que, por natureza, não gera a preempção. Para amparar essa conclusão, o mencionado autor refere que a exclusão do direito de preferência está relacionada com o caput do art. 171, o qual trata especificamente da aplicação do direito de preempção na subscrição de ações, corroborando a noção de que a opção confere o direito de subscrever ações e não de comprá-las ${ }^{238}$.

Quanto à disciplina legal da opção de compra de ações, encontramos referências ao instituto em diversos dispositivos ao longo da lei de sociedades anônimas que não o regulou em separado como o fez com o bônus de subscrição. É necessário, portanto, construir a sua disciplina a partir das múltiplas referências à opção de compra de ações. A principal está no art. $168, \S 3^{\circ 239}$.

A partir da redação encontrada no $\$ 3^{\circ}$ do art. 168 , entendemos que o direito de opção de compra é uma outorga de direito de subscrição de ações a pessoas específicas, as quais tem relação jurídica com a companhia emissora ou com a sociedade sob seu controle. Por ser uma outorga, entende-se que a opção é um instrumento gratuito ${ }^{240}$. Essa gratuidade, porém, não significa a graciosidade das ações, cuja subscrição depende do pagamento do preço correspondente.

De acordo com as principais características indicadas na lei, depreende-se que a opção de compra de ações é uma (i) outorga, (ii) fundada em plano aprovado por assembléia geral, (iii) destinada a pessoas que prestam serviços à companhia. Assim, a opção de compra de ações é compatível com a ideia de um benefício que empregados e prestadores de serviço à companhia recebem em decorrência da relação jurídica

\footnotetext{
${ }^{238}$ GUERREIRO, José Alexandre Tavares. Regime Jurídico do Capital Autorizado, p. 118.

${ }^{239}$ Art. 168. O estatuto pode conter autorização para aumento do capital social independentemente de reforma estatutária. (...)

$\$ 3^{\circ} \mathrm{O}$ estatuto pode prever que a companhia, dentro do limite de capital autorizado, e de acordo com plano aprovado pela assembléia-geral, outorgue opção de compra de ações a seus administradores ou empregados, ou a pessoas naturais que prestem serviços à companhia ou a sociedade sob seu controle.

${ }^{240}$ KOHLER, Claudio. Bônus de Subscrição, p. 104. A respeito da natureza gratuita, ao discorrer sobre o instituto, Eizirik o caracteriza como "promessa unilateral da companhia, usualmente de caráter gratuito para os beneficiários (...)”, cf. EIZIRIK, Nelson. A Lei das S/A Comentada, vol. II, p. 480
} 
estabelecida com a sociedade emissora, permitindo que as pessoas especificadas na lei participem de eventual valorização das ações ${ }^{241}$.

A definição pelo mencionado $\S 3^{\circ}$ dos beneficiários da opção de compra de ações evidencia a natureza intuitu personae do instituto, a qual se confirma com base na exclusão do direito de preferência estabelecido pelo $\S 3^{\circ}$ do art. 171. Se não reconhecido o caráter personalíssimo da opção de compra de ações, levando em conta a graciosidade do título, este poderia ser confundido como uma liberalidade incompatível com os fins sociais ${ }^{242}$, o que certamente não coincide com a lógica da lei e com sua interpretação sistemática.

Por constituir um direito personalíssimo, afirma a doutrina preponderante que o direito de opção de compra de ações somente pode ser exercido pela pessoa a quem foi conferido, motivo pelo qual é intransferível a terceiros ou, ainda, a outros empregados e administradores relacionados à companhia ${ }^{243}$.

Desse modo, a opção de compra não constitui título autônomo, nem se destina à circulação no mercado. O instrumento possibilita tão somente que administradores, empregados e prestadores de serviço participem dos lucros da companhia e da valorização das ações de sua emissão no mercado como forma de incentivar o ingresso ou a permanência na companhia e premiar seus esforços e produtividade, daí sua outorga ter caráter gratuito $^{244}$.

Algumas das características da opção de compra de ações apresentadas são semelhantes ao bônus de subscrição, tais como a possibilidade de emissão exclusivamente por sociedade anônima sob o regime de capital autorizado e o fato de que o objeto de ambos é o direito do titular participar do capital social da companhia mediante uma opção para subscrever ações ${ }^{245}$ por um preço previamente estabelecido. Ou seja, mesmo após a outorga da opção ou a aquisição ou atribuição do bônus de subscrição, não há obrigatoriedade em exercer o direito de subscrever ações, competindo ao titular a escolha.

Por outro lado, os institutos se distinguem essencialmente no que tange a sua finalidade. A opção de compra de ações, diferentemente do bônus de subscrição, visa a

\footnotetext{
${ }^{241}$ ARAGÃO, Paulo Cezar. Opções de Compra de Ações e Bônus de Subscrição, p. 64.

${ }^{242}$ CLARK, Robert C. Corporate Law. Boston: Little, Brown and Company, 1986, p. 198.

${ }^{243}$ EIZIRIK, Nelson. A Lei das S/A Comentada, vol. II, p. 483. Em sentido contrário, LOPES, Mauro Brandão. S.A.: Títulos e contratos novos, p. 87, refere que "a natureza da obrigação, que é de prêmio outorgado a pessoas determinadas, não implica impossibilidade de cessão, como também não traz a lei proibição alguma. Resta assim a convenção com o devedor, a companhia emitente; e como a outorga é necessariamente gratuita, a possibilidade existe sem dúvida de a companhia outorgar a opção com a condição de sua intransferibilidade".

${ }^{244}$ EIZIRIK, Nelson. A Lei das S/A Comentada., vol. II, pp. 462-463.

${ }^{245}$ GUERREIRO, José Alexandre Tavares. Regime Jurídico do Capital Autorizado, p. 119.
} 
incentivar a produtividade dos colaboradores da companhia ("administradores, empregados ou pessoas naturais que prestem serviços à sociedade e suas controladas"), motivando o capital humano da sociedade a gerar melhores resultados. O bônus de subscrição, a seu turno, tem como objetivo, em regra, capitalizar a sociedade ou atuar como facilitador na colocação de valores mobiliários pela companhia.

Ademais, diante dos aspectos apresentados em relação à opção de compra de ações, é fácil perceber que esta não possui natureza de título de crédito, a qual é evidente no bônus de subscrição. Enquanto a opção de compra de ações tem circulabilidade limitada ou inexistente, já que sua cessibilidade pode ser restringida apenas aos sucessores dos outorgados (em caso de falecimento do titular) ou até mesmo ser absolutamente vedada, em regra, o bônus de subscrição é um título de essência negocial com vocação para o mercado, uma vez que concebido para a captação de recursos para a sociedade. Entretanto, conforme argumentado no item 2.7 do capítulo 2, admite-se a possibilidade do bônus de subscrição não negociável.

A natureza jurídica da opção de compra é de promessa unilateral de contratar por parte da companhia e o seu exercício ocorre com a subscrição de ações ${ }^{246}$. Não tem natureza de valor mobiliário, pois não se reveste da qualidade de título autônomo destinado a circulação no mercado. O exercício do bônus de subscrição, assim como da opção, também envolve a subscrição de ações, porém a aquisição onerosa do mesmo corresponde a negócio jurídico bilateral. Quando o bônus de subscrição é emitido em sua modalidade gratuita para ser atribuído como vantagem especial a titulares de debêntures ou ações, a ausência da bilateralidade das obrigações o transforma em promessa unilateral de contratar como a opção de compra de ações.

A lei exige, ainda, que a opção de compra esteja prevista no estatuto da companhia e que o plano de outorga seja aprovado pela assembléia geral (art. 168, $\S 3^{\circ}$ ). Esses requisitos denotam um tratamento mais cuidadoso por parte da lei pra proteger os acionistas em relação à concessão da opção de compra, o que não se verifica no regime jurídico aplicável ao bônus de subscrição, que admite a sua emissão pelo conselho de administração mediante autorização estatutária. Considerando que a opção de compra pode ser concedida aos administradores da companhia, é requisito de validade a aprovação do

\footnotetext{
${ }^{246}$ Sobre o contrato preliminar, PEREIRA, Caio Maio da Silva. Instituições de direito civil, vol. III, 11. ed., Rio de Janeiro: Forense, 2004, p. 84: "Como contrato unilateral, gera obrigações para uma das partes, ao passo que a outra tem a liberdade de efetuar ou não o contrato, conforme suas conveniências". GUERREIRO, José Alexandre Tavares. Sobre Opção de Compra de Ações, p. 228.
} 
plano pela assembléia geral, a fim de que não fique caracterizado ato de liberalidade da $\operatorname{administração~}^{247}$.

Quanto ao direito de preferência, a lei o exclui em relação à opção de compra de ação em sentido coerente com a finalidade do instituto. Isso porque, diferentemente do bônus de subscrição, a opção não tem como objetivo o financiamento da empresa, mas o estímulo de colaboradores. Desse modo, considerando que a emissão de opção é limitada aos colaboradores (e não aberta ao mercado), presume-se que esta não repercute no mesmo grau, em termos de diluição dos antigos acionistas como o bônus de subscrição. Este sim pode gerar uma alteração mais significativa na proporção das participações acionárias e, consequentemente modificar direitos políticos e patrimoniais dos antigos acionistas.

O direito de preferência, assim, é a regra para o bônus de subscrição, admitindo-se, porém, sua exclusão na hipótese legal (art. 172). A diluição dos antigos acionistas, nesse caso, é permitida em virtude do interesse social em aumentar o capital social decorrente do exercício do bônus de subscrição.

No plano de opção de compra de ações, além das exigências legais, é usual serem estabelecidas cláusulas sobre a sua administração, hipóteses de desligamento dos outorgados, critérios gerais de fixação de cada outorga, percentual máximo do capital da companhia que poderá ser oferecido na forma de opções ${ }^{248}$, bem como regras que subordinam o exercício do direito incorporado pela opção à permanência do titular na companhia ou a um período aquisitivo e restrições a sua cessibilidade.

Sobre a possibilidade da companhia oferecer ações mantidas em tesouraria ao titular que exercer a opção de compra (ao invés subscrever novas ações), não encontramos vedação expressa na lei em relação a tal prática ${ }^{249}$. Em que pese a sistemática da opção de compra de ações apontar no sentido de que o direito por ela conferido é o de subscrição, parece-nos possível o aproveitamento das ações em tesouraria para essa finalidade, respeitadas as restrições legais ${ }^{250}$.

\footnotetext{
${ }^{247}$ EIZIRIK, Nelson, Lei das S/A Comentada, vol. II, p. 482.

${ }^{248}$ EIZIRIK, Nelson. A Lei das S/A Comentada, vol. II, p. 482.

${ }^{249}$ GUERREIRO, José Alexandre Tavares. Sobre Opção de Compra de Ações. In: Revista de Direito Mercantil, vol. 39, p. 228.

${ }^{250}$ Paulo Aragão entende ser possível que, diante do exercício do direito de opção, a companhia cumpra com sua obrigação mediante ações em tesouraria adquiridas para esse fim ao invés de emitir novas ações, cf. ARAGÃO, Paulo Cezar. Opções de Compra de Ações e Bônus de Subscrição, p. 64. No mesmo sentido, é a posição de Eizirik, para quem a opção de compra de ações admite duas possibilidades: que seja conferido o direito a subscriçãa de novas ações e a opção de compra de ações em tesouraria, cf. EIZIRIK, Nelson. A Lei das S/A Comentada, vol. II, p. 478.
} 
$\mathrm{O}$ art. 30 da lei de sociedades anônimas e os artigos $2^{\circ}$ e $8^{\circ}$ da Instrução CVM n ${ }^{\circ}$ 10/80 estabelecem restrições à possibilidade da companhia adquirir as próprias ações para permanência em tesouraria, visando proteger o mercado de capitais de condições artificiais de oferta e demanda, fraude por parte do acionista controlador, redução do capital social, entre outras. $\mathrm{O}$ art. $3^{\circ}$ da mesma Instrução CVM combinado com o art. $5^{\circ}$ dispõe sobre a limitação do número de ações que a companhia pode manter nessas condições.

A propósito, vale acrescentar que no Processo CVM n RJ 2002/2935, a Comissão de Valores Mobiliários autorizou a compra de ações para manutenção em tesouraria a fim de que a companhia pudesse vendê-las a beneficiários de plano de opção de compra de ações destinado a administradores e empregados ${ }^{251}$.

Sobre os planos de opção de compra de ações para administradores e empregados, cumpre referir que estes conferem vantagem tributária tanto no direito norte-americano ${ }^{252}$ como no brasileiro. No direito pátrio, não há incidência de tributos sobre a outorga destas opções, já que ausente o acréscimo patrimonial que justificaria a incidência do imposto sobre a renda nesta operação ou hipótese de incidência tributária de caráter previdenciário. A tributação ocorrerá sob a forma de ganho de capital sobre os dividendos pagos ou creditados decorrentes das ações que forem subscritas com exercício das opções.

Por fim, é possível concluir que, apesar de compartilhar semelhanças com o bônus de subscrição, a opção de compra de ações submete-se a regime jurídico completamente distinto e específico. Foram justamente as diferenças que separam a subscrição de ações decorrentes do exercício da opção de compra daquela promovida pelo exercício de bônus de subscrição que fundamentaram o julgamento do Processo CVM no SP 2002/0474, o qual será analisado mais detidamente no item 4 do Capítulo 5.

\footnotetext{
${ }^{251}$ Em conclusão do voto a Relatora do Processo, Norma Jonssen Parente, determinou o seguinte: "17. Ante o exposto, VOTO no sentido de conceder a autorização para que a companhia venda em operação privada ações de sua própria emissão mantidas em tesouraria aos beneficiários do plano, bem como recompre essas ações em caso de exercício do direito de preferência, devendo, ainda, ser atendidas as exigências da SEP constantes às fls. 49 dos autos, dentre as quais cabe destacar a necessidade de divulgação do plano em notas explicativas às demonstrações financeiras (DP e ITR) e no formulário eletrônico IAN com o objetivo de oferecer aos investidores a maior transparência possível, bem como as que eventualmente vierem a ser feitas relativas ao plano propriamente dito." Voto proferido em 10/10/2002, em julgamento ao Processo RJ2002/2935 sobre plano de opção de compra de ações da Santista Têxtil S.A.

${ }^{252}$ No caso de planos de opção de compra de ações outorgadas a executivos, quando atendidos os requisitos do Internal Revenue Code ( $130 \mathrm{~A})$ o maior incentivo para as companhias recompensarem seus empregados é a tributação incidente sobre os ganhos de capital que cuja alíquota é menor do que imposto sobre a renda incidente sobre salário e bônus, cf. CHOPER, Jesse H.; COFFEE JUNIOR., John C.; MORRIS JUNIOR., C. Robert. Cases and Materials on Corporations. 3 ed., Boston: Little, Brown and Company, 1989, p. 301.
} 


\section{Opção de compra de ações negociada em bolsa de valores}

No primeiro capítulo deste trabalho, referimos que a terminologia de origem do bônus de subscrição (stock option ${ }^{253}$ ) no direito norte-americano é ambígua e que, no direito brasileiro, foram adotados termos distintos para caracterizar a stock option como opção de compra de ações ou para significar bônus de subscrição. No Brasil, a nomenclatura "opção de compra de ações”, por sua vez, também é ambígua, pois é o nome típico para três aplicações distintas. Uma delas foi objeto de análise no item anterior e diz respeito ao instrumento outorgado gratuitamente a empregados, administradores e prestadores de serviços (art. $168, \S 3^{\circ}$ ). Outra é a opção de compra de ações como "negócio por meio do qual um dos sujeitos resguarda o direito de, a seu critério e unilateralmente, dentro de um prazo estabelecido, dar vida a uma relação jurídica de compra e venda de ações" ${ }^{254}$. A terceira aplicação ${ }^{255}$ é aquela em que o titular da ação aliena ao adquirente direito de comprá-la por meio da bolsa de valores, mediante o pagamento do preço de exercício fixado e no prazo avençado ${ }^{256}$.

Esta última será o nosso objeto de exame neste ponto, pois, assim como a opção de compra de ações destinadas aos administradores, serve como contraponto para ressaltar os elementos essenciais do bônus de subscrição.

A opção de compra de ações negociada em bolsa de valores (exchange-traded stock option) é um negócio jurídico celebrado entre duas pessoas, onde uma se obriga a comprar

\footnotetext{
${ }^{253}$ CINTRA, Maria Lucia Borges de Araújo. Aspectos jurídicos dos bônus de subscrição, p.11: “(...) tanto o bônus de subscrição como a opção de compra de ações são inspirados em um mesmo instituto do direito norte-americano, o chamado stock option, o qual, ao ser transplantado para nosso direito deu origem a dois diferentes institutos, cada qual com suas características próprias, embora conservando alguns aspectos comuns." No nosso entender, no direito norte-americano, existem as duas figuras - bônus de subscrição e opção de compra de ações outorgadas as administradores e empregados, a diferença é que no direito estrangeiro, não há rigor em tipificar a nomenclatura como em nosso sistema jurídico.

${ }^{254}$ IGLESIAS, Felipe Campana Podem. As opções de compra ou venda de ações no direito brasileiro: natureza jurídica e tutela executiva judicial. Dissertação de mestrado, Faculdade de Direito da Universidade de São Paulo, 2013, p. 7-8 e 12-13. De acordo com o autor a nomenclatura como opção de compra ou opção de venda é definida conforme a "natureza jurídica do direito criado em favor do sujeito beneficiário", podendo abranger qualquer bem lícito e transferível.

${ }^{255}$ As opções de compra de ações podem ser encontradas na doutrina norte americana como exchange-traded stock option e, no Brasil, além da nomenclatura de “opção de compra de ações”, também foi adotado o termo warrant, de acordo com a Instrução CVM n⿳0 223, de 1994, que abrange a opção sobre compra e venda de ações de companhia aberta, bem como de debêntures simples ou conversíveis em ações, entre outros. Vide também Manual de Mercado de Derivativos da Bm\&fBovespa sobre Opções de Compra Não-Padronizadas Warrants, disponível em http://www.bmfbovespa.com.br/pdf/warrants.pdf, acessado em 12/11/2014.

${ }^{256}$ MITCHELL, Lawrence E; SOLOMON, Lewis D. Corporate Finance and Governance: Cases, Materials and Problems for an Advanced Course in Corporations. Durham: Carolina Academic Press, 1992, p. 440: "Warrants are options to purchase a specified number of shares of stock (or other securities) at a specified price on or before a specified date. Warrants often are sold together with other securities, such as bonds, as a package".
} 
ações da outra, mediante manifestação desta dentro das condições, do prazo e do preço previamente acordados. Ou seja, o titular da opção de compra pode escolher se deseja ou não exercer o seu direito na data determinada. Nesse caso a opção é considerada um derivativo, na medida em que o seu valor tem conexão direta com o valor do ativo (ação) subjacente cujo direito de compra é negociado ${ }^{257}$.

A primeira diferença que se apresenta é que a opção de compra não envolve a participação da companhia cujas ações são negociadas. No bônus de subscrição, a oferta de subscrever ações, se origina exclusivamente da companhia. Consequentemente, o direito incorporado é o de "subscrição" e, não o de "compra" como ocorre com a opção. Assim, enquanto na opção o ativo subjacente são ações já subscritas (mercado secundário), no bônus de subscrição, as ações ainda não existem e somente podem ser emitidas pela própria sociedade anônima que emitiu esse título. No caso do seu exercício, necessariamente os acionistas sofrem diluição em suas participações (já que envolve a emissão de novas ações), ao contrário das opções que abrangem ações em circulação.

Os dois instrumentos, porém, são semelhantes no que se refere aos efeitos finais do seu exercício, do ponto de vista dos titulares do direito conferido pelo bônus e pela opção, pois em ambos os casos eles passarão à condição de acionistas da companhia (regra geral). As condições para o exercício do bônus de subscrição são unilateralmente definidas pela companhia quando de sua emissão. Na opção que ora tratamos, por ser negociada em bolsa, seus parâmetros também não são livremente pactuados pelas partes, na medida em que devem seguir a padronização quanto a data de vencimento, tipo de liquidação e outros critérios definidos no Regulamento da bolsa de valores ${ }^{258}$.

Tanto os titulares de bônus de subscrição e como o de opção de compra de ações realizam o negócio com base na expectativa de que, na data do exercício, o valor de mercado da ação sobre o qual é contratada a opção (ou bônus), será maior que o preço previamente determinado. Caso não seja vantajoso o exercício, as partes são liberadas da

\footnotetext{
${ }^{257}$ SOUZA JUNIOR, Francisco Satiro de. Regime Jurídico das Opções Negociadas em Bolsas de Valores, p. 24 e 75: "A opção de compra de ativos em bolsa também é chamada "call". Por ela, uma pessoa ("lançador") garante a outra pessoa ("titular") mediante o recebimento de um valor pré-estabelecido ("prêmio") o direito de, em querendo, adquirir ativos por um preço determinado ("preço de exercício") até uma data estabelecida ("data de vencimento ou de exercício")".

${ }^{258}$ Cf. Apostila da BM\&FBoveSPA, Capítulo 6, p. 4: "Contratos padronizados são contratos que possuem estrutura previamente padronizada por regulamentação de bolsa, estabelecendo todas as características do produto negociado, como cotação, data de vencimento, tipo de liquidação e outras. A padronização dos contratos é condição imprescindível para que a negociação possa ser realizada em bolsa.", disponível em http://lojavirtual.bmf.com.br/LojaIE/portal/pages/pdf/Apostila_PQO_Cap_06_Parte_A_V2.pdf, acessado em $12 / 11 / 2014$.
} 
relação jurídica contratada, extinguindo-se no prazo fixado o bônus de subscrição e a opção de compra de ações.

O exercício da opção de compra de ações, todavia, não se restringe à possibilidade do titular optar por receber as ações contratadas. Nas opções negociadas em bolsa, o titular poderá optar, ainda, por liquidar o contrato por diferença (nas bolsas de valores que admitem essa espécie de execução contratual). Na liquidação por diferença, o lançador (proprietário das ações negociadas) deposita junto ao agente de compensação a diferença entre o valor de mercado da ação e o preço de exercício determinado na negociação da opção, descontado o valor atualizado do prêmio (valor pago pela opção) e os custos de transação.

No caso do bônus de subscrição, nem a companhia nem o titular tem alternatividade quanto à prestação final do título. Se exercitado, ao titular sempre corresponderá a subscrição das ações, cabendo à sociedade emissora tão somente sujeitar-se ao exercício do direito conferido pelo título. Além disso, o valor pago pelo bônus de subscrição não tem qualquer influência sobre o valor a ser pago pelo investidor na subscrição de ações. Terá relevância apenas no cálculo econômico sobre a decisão de subscrever ou não as ações, mas jamais poderá ser confundido como adiantamento em relação ao preço das ações. Tanto o prêmio como o preço do bônus de subscrição não se confundem com sinal ou cláusula penal, porque são devidos independentemente do exercício do direito incorporado pelos títulos.

Outra particularidade da negociação da opção, que não é comum ao bônus de subscrição, é a chamada opção descoberta, a qual compreende a possibilidade de negociar opções com quem não tem a propriedade dos ativos negociados. Geralmente, para essa operação são exigidas do lançador garantias adicionais (margens) pela caixa de liquidações, com o objetivo de assegurar o cumprimento da prestação ${ }^{259}$.

\section{Debênture conversível em ação}

O último instituto que será comparado ao bônus de subscrição é a debênture conversível em ação, a qual consiste em um valor mobiliário representativo de dívida que

${ }^{259}$ SOUZA JUNIOR, Francisco Satiro de. Regime Jurídico das Opções Negociadas em Bolsas de Valores, p. 85. 
assegura a seus detentores direito de crédito contra a companhia emissora ${ }^{260}$ com cláusula de conversibilidade ${ }^{261}$, a qual garante ao titular a opção de substituir o investimento em título de dívida por ações da companhia emissora nas condições constantes da escritura de emissão (art. 57)

A debênture não corresponde a mero mútuo, na medida em que o montante da dívida que será objeto da emissão é repartido entre diversos títulos que podem ser adquiridos por múltiplos investidores. Isto é, cada título detém uma parcela específica da dívida que dentro da série na qual foi emitida é "padronizada, fungível e confere os mesmos direitos a seus titulares, na proporção do número das debêntures que cada um possuir" $" 262$.

Em termos gerais, a debênture conversível em ação pode ser uma alternativa financeiramente mais atrativa aos empréstimos bancários, do ponto de vista da companhia, pelo fato de abranger taxas de juros inferiores às cobradas por instituições financeiras e maior prazo para pagamento do mútuo ${ }^{263}$.

A valorização do direito de conversão do título ocorre quando os dividendos das ações objeto de conversão pago aos acionistas da companhia emissora forem maiores que os juros estabelecidos para remuneração do capital investido, ou também quando o custo das ações for superado pelo seu valor de mercado. Assim, a avaliação acerca do valor do direito de conversão dependerá tanto da rentabilidade das ações da companhia em questão como da sua cotação de mercado ${ }^{264}$.

A conversibilidade em ações conferida à debênture proporciona mais atratividade ao título em relação à debênture que não confere o direito de conversão, caracterizando-se por uma vantagem extra ao investidor e uma alternativa à captação de recursos por meio da emissão de ações sem a necessidade de posteriormente restituir o valor captado. A emissão de debêntures conversíveis pode ser uma estratégia da administração da companhia para

\footnotetext{
${ }^{260}$ MUSSNICH, Francisco Antunes Maciel. As recentes alterações com respeito à competência para emissão de debêntures, p. 539.

${ }^{261}$ GUIMARÃES, Francisco José Pinheiro. Debêntures, p. 595: “A cláusula da conversibilidade assegura ao titular da debênture a opção por substituir o seu investimento em título da dívida por ações da companhia emissora. O exercício dessa opção assegura ao debenturista: (a) aumento de rendimento, quando há previsão de que os dividendos a serem distribuídos às ações serão superiores ao juros das debêntures, ou (b) ganho de capital, quando o custo de aquisição das ações, resultantes das bases de conversão, é inferior ao valor de mercado das ações."

${ }^{262}$ MUSSNICH, Francisco Antunes Maciel. As recentes alterações com respeito à competência para emissão de debêntures, p. 540.

${ }^{263}$ MITCHELL, Lawrence E; SOLOMON, Lewis D. Corporate Finance and Governance: Cases, Materials and Problems for an Advanced Course in Corporations, p. 441. EIZIRIK, Nelson. A Lei das S/A Comentada, vol. I, p. 318.

${ }^{264}$ GUIMARÃES, Francisco José Pinheiro. Debêntures, p. 595.
} 
quando a cotação das ações no mercado estiver baixa para a realização de aumento de capital por subscrição de ações. Utilizando-se as debêntures conversíveis é possível forçar a conversão quando o valor da ação estiver no patamar desejado, tornando a operação mais rentável para a companhia ${ }^{265}$.

O risco nessa operação se revela quando o preço das ações não alcança o patamar esperado e a companhia tem o dever de restituir o valor da debênture. O bônus de subscrição, por esse prisma, não apresenta esse mesmo risco financeiro para a companhia, já que esta não tem a obrigação de restituir o valor de emissão do título.

Além da possibilidade de subscrever ações a preço superior (em relação a uma oferta pública para subscrição regular de ações), por exemplo, as debêntures em questão, na qualidade de obrigações conversíveis, geram para a companhia menor risco de inundar o mercado com ações, evento que, em última análise, pode causar a queda do preço ante um desequilíbrio entre oferta e demanda por tais valores mobiliários ${ }^{266}$.

A emissão de títulos conversíveis, portanto, é uma boa oportunidade para companhias que desejam captar recursos para equity com maior controle sobre o valor de subscrição das ações e uma possibilidade de postergar a diluição de dividendos para quando houver a conversão em ações e aumentar a aceitação do título no mercado ${ }^{267}$.

Assim como o bônus de subscrição, a debênture é um valor mobiliário (art. $2^{\circ}, \mathrm{I}$, Lei $\left.n^{\circ} 6.385 / 76\right)$ que se caracteriza como instrumento de captação de recursos com capacidade de negociação e circulação em massa no mercado de capitais. Ao mesmo tempo, a debênture abrange os requisitos dos títulos de crédito, na medida em que incorpora uma obrigação pecuniária com as características da cartularidade, literalidade e autonomia próprias desta categoria ${ }^{268}$.

${ }^{265}$ EIZIRIK, Nelson. A Lei das S/A Comentada, vol. I, p. 350. No mesmo sentido, MITCHELL, Lawrence E; SOLOMON, Lewis D. Corporate Finance and Governance: Cases, Materials and Problems for an Advanced Course in Corporations, p. 440: "convertibles provide a way to sell common stock at prices higher than those currently prevailing. Many companies actually want to sell common stock, and not debt, but feel that the price of their stock is temporarily depressed".

${ }^{266}$ BOGEN, Jules I. Corporation Finance, p. 143: “After the entire bond issue is converted, the Eclipese Manufacturing Company finds that by selling convertible bonds instead of common stock it benefited in the following ways. First, it secured at least $\$ 15$ more for each share of its stock that it would have if it had sold stock at the outset. In other words, its convertible bonds provided a means of selling its stock way above the going market price. In the second place, the company avoided creating a large excess of supply of its stock in the market, which would have tended to force down the price well below 80 at the time, thus making necessary still larger issue of stock in order to raise the needs amount of money".

${ }^{267}$ CARY, William L.; EISENBERG, Melvin Aron. Cases and Materials on Corporations, p. 1145-1146.

${ }^{268}$ GUIMARÃES, Francisco José Pinheiro. Debêntures, p. 580. Em sentido contrário, AMARAL, José Romeu Garcia do. Regime Jurídico das debêntures. São Paulo: Almedina, 2014, p. 57-58: “a característica decisiva para concluir que as debêntures são valores mobiliários, e não títulos de créditos stricto sensu, é a sua serialidade, a sua emissão em conjuntos homogêneos ou em massa (...). Não restam dúvidas, portanto, que as debêntures não se encaixam na disciplina dos títulos de crédito" 
Os traços de semelhança mais evidentes entre a debênture conversível em ação e o bônus de subscrição dizem respeito à finalidade, à emissão e parte dos direitos incorporados por esses títulos. Tanto um como o outro tem em comum a finalidade de fornecer recursos para a realização da atividade negocial da companhia. Quanto ao objeto, ambos conferem aos seus titulares o direito de se tornarem acionistas da sociedade emissora e, no caso das debêntures, se não exercido o direito de conversão, o titular permanece com o direito de crédito, o qual pode incluir juros, participação nos lucros da companhia e prêmio de reembolso (art. 56).

Quanto à emissão, a da debênture poderá ser feita por companhia aberta ou fechada e também pela sociedade em comandita por ações (art. 283). O bônus de subscrição pode ser lançado mediante emissão (i) privada, tanto por sociedade fechada como aberta, ou (ii) pública, no mercado de capitais, naturalmente, apenas por sociedade aberta. No tocante à sociedade em comandita por ações, por expressa vedação legal (art. 284), este tipo societário está impedido de emitir bônus de subscrição.

Outro aspecto semelhante é que a debênture conversível em ação, apesar de não ser instituto privativo da sociedade anônima sob o regime de capital autorizado, pode ser emitida mediante deliberação do conselho de administração de companhia aberta (art. 59, $\left.\S 2^{\circ}\right)^{269}$. O mesmo se aplica ao bônus de subscrição, no âmbito das companhias de capital autorizado, desde que o estatuto social assim estabelecer (art. 76).

Nos termos do art. 137, o acionista que não aprovar a emissão de debêntures conversíveis em ações ou bônus de subscrição não terá direito de retirada quando submetida à deliberação da asssembleia geral. Caberá aos acionistas atentar para o preço de subscrição das ações que, conforme já explicitado anteriormente, possuem parâmetros que o protegem da diluição que esses títulos acarretam.

Dentre as semelhanças, pode-se citar ainda que tanto o bônus de subscrição como a debênture conversível em ação não constituem, desde logo, uma participação no capital da companhia. Em ambos os casos, o titular se torna acionista apenas depois que manifesta seu interesse na subscrição e na conversão, respectivamente. Contudo, na hipótese do bônus de subscrição, o exercício demanda o pagamento do preço de subscrição; enquanto

\footnotetext{
${ }^{269}$ YAZBEK, Otávio. A Modernização do Regime das Debêntures e a Criação de um Mercado de Dívida de Longo Prazo. In: CASTRO, Rodrigo Rocha Monteiro de; WARDE JÚNIOR, Walfrido Jorge; GUERREIRO, Carolina Dias Tavares. Direito Empresarial e outros estudos de direito em homenagem ao Professor José Alexandre Tavares Guerreiro. São Paulo: Quatier Latin, 2013, p. 579: "No que tange às debêntures conversíveis em ações, optou-se pela permissão de deliberação de emissão pelo conselho dentro do limites do capital autorizado - o que é, no mínimo, coerente com a existente com as regras de capital autorizado no sistema societário brasileiro."
} 
na conversão da debênture, não há qualquer desembolso, pois este já foi realizado quando da aquisição do título.

Distinguem-se os dois institutos, porém, em relação às consequências do não exercício. Caso o debenturista opte por não converter o seu título em ações, o valor pago pela debênture é totalmente restituído ao titular, o que não ocorre com o titular de bônus de subscrição que, optando por não subscrever ações, perderá o valor do investimento desembolsado quando da emissão do título.

Com base na evolução legislativa e tecnológica, como já explicitado no item 1.2.3 do Capítulo 2 em relação ao bônus de subscrição, a debênture conversível em ação, em igual medida, ainda que possua a natureza de título de crédito, não precisa observar o processo tradicional de cartularização ${ }^{270}$, já que sua materialização ocorre por processo eletrônico, de modo que a emissão em papel é equiparada ao lançamento do título no sistema de registro ou livro, conforme o caso.

A debênture, de modo geral, tem como característica marcante a existência de uma vinculação entre os seus investidores por força da comunhão de interesses e pela sua representação pelo agente fiduciário perante a companhia emissora. Esse aspecto "coletivo" decorre das diversas disposições legais acerca da necessidade de aprovação de determinadas operações da sociedade pelos debenturistas como, por exemplo, em caso de redução de capital, na qual a lei exige a aprovação por maioria em assembleia geral dos debenturistas (art. 174, $3^{\circ}$ ), na própria previsão de assembleia de debenturistas (art. 71), contratação de agente fiduciário (art. 66), cuja nomeação já deve constar na escritura de emissão, assim como as demais condições de remuneração e substituição. Os titulares de bônus de subscrição, entretanto, não possuem as mesmas prerrogativas dos debenturistas, os quais possuem posição privilegiada de credores (art. 231) ${ }^{271}$.

A lei silencia sobre a necessidade de consulta dos titulares de bônus de subscrição em assembleia geral, de modo que a titularidade do bônus de subscrição confere-lhes a posição de credores comuns, não possuindo direito de oposição como os debenturistas, exceto quando violados os direitos e as condições estabelecidas na sua emissão ou em caso de "anulação das operações praticadas pela sociedade em prejuízo do valor da subscrição

\footnotetext{
${ }^{270}$ EIZIRIK, Nelson. A Lei das S/A Comentada, vol. I, p. 322.

${ }^{271}$ A aprovação por parte dos debenturistas pode ser dispensada se a companhia assegurar aos debenturistas o resgate das debêntures, nos termos do $\S 1^{\circ}$ do art. 231 .
} 
previsto no título, ou seja, a diluição desse mesmo valor por meio de operações sociais, ainda que legítimas em si (art. 232),272.

Conforme já referido, a conversão de debêntures em ações não implica em alteração do patrimônio da companhia, pois não há ingresso de novos recursos (como sucede na subscrição de ações decorrentes do exercício do bônus de subscrição). Na conversão das debêntures, é realizada uma operação contábil de conversão de reservas para resgate em capital, havendo mera transferência de $\operatorname{contas}^{273}$. 


\section{CAPÍTULO 5 - O BÔNUS DE SUBSCRIÇÃo NA PRÁtica SOCIETÁRIA}

O presente trabalho tem como principal objetivo o estudo do regime jurídico do bônus de subscrição, motivo pelo qual, até o presente capítulo, todas as atenções estavam voltadas para os contornos legislativos e para a interpretação da doutrina acerca do instituto. Nesta parte, contudo, nossa meta é abordar a aplicação do bônus de subscrição na prática societária, cuja abrangência, segundo nossa pesquisa, ainda é tímida.

Nosso intuito não é encontrar a fundamentação para essas práticas, mas trazer para o campo da dogmática o exame de situações limítrofes envolvendo a emissão de bônus de subscrição, de modo a estimular a evolução do arcabouço jurídico, por entendermos que os institutos jurídicos somente sobrevivem se encontrarem função na realidade.

\section{A negociação do bônus de subscrição na BM\&FBOVESPA}

Nesse último capítulo, destinado à prática societária do bônus de subscrição, buscamos apresentar dados empíricos sobre a utilização do nosso objeto de estudo. De acordo com o Capítulo 2, onde delineamos a finalidade e os requisitos do bônus de subscrição, ressaltamos o seu objetivo de capitalização da companhia, ressaltando que o "grande atrativo deste título, do ponto de vista do investidor, está no fato de ele conferir o direito de subscrever ações a um preço previamente estabelecido" ${ }^{274}$.

Conforme pesquisa acerca da negociação de bônus de subscrição junto à BM\&FBOVESPA, constatamos que o volume negociado não é relevante. Na referida bolsa de valores, atualmente são negociados bônus de subscrição relativos à BR Pharma (BPHA11), Iochpe-Maxion (MYPK11) e Kepler Weber (KEPL11), os quais representam em termos de volume $\mathrm{R} \$ 3,34$ por milhão ${ }^{275}$ de reais do total de títulos negociados na referida bolsa de valores. A relevância, portanto, do instituto no mercado de capitais é pequena, conforme buscamos ilustrar por meio da tabela abaixo, referente ao ano de 2014:

\footnotetext{
${ }^{274}$ EIZIRIK, Nelson L. GAAL, Ariádna B., PARENTE, Flávia, HENRIQUES, Marcus de Freitas. Mercado de Capitais: Regime Jurídico, p. 79.

${ }^{275}$ Considerando a divisão do valor total referente à negociação do bônus de subscrição (R \$ 5.918.974,00) pelo total geral de negociação ( $\mathrm{R} \$ 1.770 .910 .024 .562,23)$ na BM\&FBOVESPA.
} 


\begin{tabular}{|c|c|c|}
\hline & \multicolumn{2}{|c|}{$\begin{array}{c}\text { Totais dos pregões } \\
\text { Ref: Dez/2013 - Nov/2014 }\end{array}$} \\
\hline Mercados & Negociações & Volume (R\$) \\
\hline Lote-Padrão & 195.682 .982 & 1.578.897.150.272,83 \\
\hline Recuperação Judicial / Extrajudicial & 464.100 & $2.076 .205 .680,00$ \\
\hline Outros & 206.136 & $387.934 .758,00$ \\
\hline Mercado à Vista - Lote-Padrão & 196.353 .218 & 1.581.361.290.710,83 \\
\hline Direitos e Recibos & 56.823 & $1.905 .685 .217,00$ \\
\hline Fundo Imobiliário & 947.087 & $5.238 .822 .673,76$ \\
\hline Cert. Invest/Tit. Div. Pub/BDR & 1.447 .593 & 26.379.287.870,41 \\
\hline Bônus (Privados) & 84 & $5.918 .974,00$ \\
\hline Exercício de Opções de Compra de Índices & 567 & $11.390 .970 .000,00$ \\
\hline Exercício de Opções de Venda de Índices & 659 & $14.140 .865 .000,00$ \\
\hline Exercício de Opções de Compra & 51.395 & $23.054 .559 .222,16$ \\
\hline Exercício de Opções de Venda & 16.638 & $18.799 .347 .980,80$ \\
\hline Leilão de não Cotados & 5 & $65.510 .422,00$ \\
\hline Leilão Funres & 14 & $1.300 .975,01$ \\
\hline Leilão & 6.295 & $9.661 .579 .713,54$ \\
\hline Leilão Finor & 37 & $2.718 .843,53$ \\
\hline Leilão Finam & 83 & $34.056 .094,15$ \\
\hline Bovespa Fix & 1.960 & $294.093 .951,89$ \\
\hline Mercado Fracionário & 2.073 .702 & $1.219 .674 .215,30$ \\
\hline Mercado à Vista - Total & 200.956 .160 & 1.693.555.681.864,38 \\
\hline Mercado a Termo & 148.322 & $20.818 .584 .411,83$ \\
\hline Mercado Futuro & 0 & 0 \\
\hline Opções de Compra de Índices & 18.566 & $4.513 .718 .120,00$ \\
\hline Opções de Venda de Índices & 24.443 & $8.086 .470 .080,00$ \\
\hline Opções de Compra & 20.085 .825 & $35.080 .451 .903,28$ \\
\hline Opções de Venda & 4.102 .150 & $8.855 .118 .182,74$ \\
\hline Mercado de Opções & 24.230 .984 & 56.535.758.286,02 \\
\hline Total Geral & 225.335 .466 & 1.770.910.024.562,23 \\
\hline
\end{tabular}

Nos últimos 5 anos, de 2010 a 2014, o volume de negociação do bônus de subscrição teve grande oscilações sem, no entanto chegar a uma representatividade importante dentre os demais títulos considerados no volume de negociação total da Bm\&fBovespa, conforme se verifica do gráfico abaixo:

\begin{tabular}{|c|c|c|c|c|c|}
\hline & \multicolumn{2}{|c|}{ Bônus de Subscrição } & Comparativo & \multicolumn{2}{c|}{ BM\&FBovESPA } \\
\cline { 1 - 2 } \cline { 5 - 6 } Ano & Negociações & Volume (R\$) & R por milhão) & Negociações & Volume (R\$) \\
\hline 2010 & 4.405 & $50.235 .537,00$ & 31,34 & 106.418 .275 & $1.602 .591 .966 .119,28$ \\
\hline 2011 & 2.514 & $38.986 .516,00$ & 24,11 & 141.229 .539 & $1.616 .386 .591 .598,30$ \\
\hline 2012 & 437 & $62.368 .646,00$ & 34,98 & 191.973 .738 & $1.782 .773 .214 .247,97$ \\
\hline 2013 & 43 & $27.057,00$ & 0,01 & 220.550 .846 & $1.839 .589 .477 .019,95$ \\
\hline 2014 & 84 & $5.918 .974,00$ & 3,34 & 225.335 .466 & $1.770 .910 .024 .562,23$ \\
\hline
\end{tabular}


Uma das razões para a baixa negociação desses títulos é o fato de que não são padronizados, na medida em que isso impacta diretamente na liquidez do título, tornando-o menos atraente para negociação e mais propenso a usos diversos e mais específicos, de acordo com a necessidade da companhia ${ }^{276}$. Isso porque a padronização diminui os custos de transação e tornam a utilização do título mais ágil e previsível.

Além disso, a emissão de bônus de subscrição implica em admitir acionistas e um tipo específico de recursos, cujos custos devem ser sopesados em comparação com os custos de outras naturezas, como dívida. Em tese, o custo do capital social é inferior ao custo do capital derivado de um empréstimo em instituição financeira, cuja remuneração depende dos juros praticados, da situação mercado e outros tantos fatores. Além disso, ao admitir novos acionistas por meio de bônus de subscrição, a companhia não tem como desfazer essa posição mais alavancada como é o caso da emissão de debêntures simples (exceto se fizer o resgate de ações, o qual deve atender aos limites legais e regulatórios pertinentes, conforme art. 44). Nessa hipótese a exposição à dívida pode ser revertida com o pagamento.

Yazbek, referindo-se ao baixo volume de negociação de debêntures, que entendemos aplicáveis ao caso do bônus de subscrição, atribui o tamanho do mercado brasileiro ao subdesenvolvimento do mercado de dívida privada comum em economias emergentes como o Brasil por reunir características como (i) governos como emissores de volumes relevantes de títulos de dívida pública provocando o efeito crowding out, que afasta os investidores dos demais títulos, (ii) taxas de juros elevadas que aumenta a taxa de atratividade dos instrumentos de dívida pública, (iii) regimes tributários inadequados ao desenvolvimento do mercado e (iv) infraestruturas de mercados de capitais não propícios ao seu desenvolvimento ${ }^{277}$.

\footnotetext{
${ }^{276}$ Ao traçar o paralelo entre o warrant do direito norte-americano com as opções de compra, o Professor Francisco Satiro, comenta que "como bem demonstra o nome do instituto ("opções não padronizadas"), o que faz o warrant do mercado de capitais brasileiro diferir substancialmente das opções de bolsa é a sua não padronização, que lhe garante uma liquidez significativamente menor, mas uma melhor adaptabilidade a fins específicos. SOUZA JUNIOR, Francisco Satiro de. Regime Jurídico das Opções Negociadas em Bolsas de Valores, p. 91.

${ }^{277}$ YAZBEK, Otávio. A Modernização do Regime das Debêntures e a Criação de um Mercado de Dívida de Longo Prazo, p. 567-568.
} 


\section{O uso do bônus de subscrição para manutenção de posição acionária}

Até o presente momento, temos indicado que a finalidade do bônus de subscrição é captar recursos para a companhia, seja por meio da emissão autônoma do título ou mediante a sua atribuição a outros valores mobiliários (ações e debêntures). Entretanto, conforme já adiantamos, o bônus de subscrição serve a outras finalidades que foram verificadas na prática societária como, por exemplo, a manutenção da participação acionária.

Durante o desenvolvimento da atividade social, é comum que surja a necessidade de injeção de capital para aumentar a capacidade produtiva do negócio, expandir a atuação empresarial, investir em inovação e novas tecnologias. Não é incomum que os acionistas que iniciaram o empreendimento desejem manter a composição societária inalterada, especialmente quando a empresa é constituída por companhia fechada. Assim, para compatibilizar as necessidades de recursos sem a contratação de dívida ou entrada de novos sócios, caberá aos próprios acionistas aportar os recursos necessários à companhia mediante aumento de capital.

No entanto, apesar de concordarem com a solução de aumentar de capital com recursos próprios dos sócios, é possível que, no momento ideal para a companhia, nem todos os acionistas estejam preparados com a liquidez necessária para realizar o aporte convencionado $^{278}$.

É nesse momento em que a prática societária exige soluções criativas. Em função da diferença em termos de capacidade financeira - à época em que os recursos são necessários - a companhia pode lançar mão da emissão de bônus de subscrição para o acionista que não tem condições de acompanhar o aumento de capital praticado pelos demais. Nessa situação, são emitidos bônus de subscrição para permitir que o acionistas que não acompanhou a referida subscrição possa fazê-lo em momento posterior e pelo valor equivalente ao da subscrição de ações realizadas pelos demais acionistas.

Além disso, por meio de cláusula de ajustamento, pode ser convencionada a compatibilização da contribuição a ser dada pelo acionista titular de bônus de subscrição frente a eventos futuros, tais como a distribuição de dividendos, por exemplo.

\footnotetext{
${ }^{278}$ Nesse sentido, GEVURTZ, Franklin A. Business Planning. Westbury: Foundation Press, 1991, p. 130: "Partners may possess unequal capability or willingness to provide additional funding. If some partners are unable to make additional contribution, those upon whom the burden falls might view themselves entitled to a greater share of firm profits (or even control) as compensation (...). While from the standpoint of the contributing partners such a demand may seem perfectly reasonable, the partners unable to contribute may feel this as an oppressive attempt to exploit an advantage".
} 
Assim, nesse caso, ao invés do bônus de subscrição funcionar para atrair recursos externos para a companhia ou para conferir maior atratividade a ações ou debêntures no mercado de capitais, o título é utilizado para a gestão das posições acionárias detidas pelos próprios acionistas de companhia, permitindo que aquele sem condições atuais de aportar o investimento convencionado, acompanhe o aumento de capital em momento futuro, alcançando a proporção de ações detidas antes do aumento de capital concluído pelos demais acionistas.

A grande vantagem da emissão desse título sobre um aumento de capital com subscrição de ações e pagamento diferido é que, ao utilizar o bônus de subscrição, a companhia somente precisará emitir ações no prazo do seu exercício e mediante pagamento do preço das ações. Ou seja, até que o acionista efetivamente pague pelas ações, os direitos patrimoniais que as futuras ações lhe conferirão podem ser resguardados, se assim ficar convencionado. Além disso, caso o acionista não realize o aporte necessário, a companhia não precisará promover a cobrança forçada decorrente do inadimplemento de ações subscritas, porém não integralizadas. Transcorrido o prazo do bônus de subscrição, extingue-se o título e com ele a oportunidade do aumento de capital, sem a necessidade de providências coercitivas para reparar o inadimplemento, o que é muito vantajoso para manter as relações entre os acionistas.

Em que pese os objetivos perseguidos quando da emissão de bônus de subscrição nessas circunstâncias sejam distintos daqueles descritos da exposição de motivos da Lei $n^{\circ}$ 6.404/76, o título segue todas as normas aplicáveis ao tema, sem desafiar o seu enquadramento jurídico conforme até aqui exposto.

\section{O bônus de subscrição como instrumento de diluição}

A diluição da participação dos acionistas de uma companhia, mesmo quando atendidas as disposições legais estabelecidas para sua proteção, em geral é considerada como um efeito colateral do aumento de capital, "um mal necessário". Esse efeito se justifica pela necessidade de captação de recursos, quando a subscrição de ações se mostra mais vantajosa que outras modalidades de atrair capital. A diluição, portanto, somente corresponderá a uma limitação ao aumento de capital quando for injustificada. 
O dia a dia das companhias mostra-se muito mais complexo do que a lei e a dogmática podem antecipar, de modo que há ocasiões em que a diluição acionária é justamente o remédio que a companhia precisa para viabilizar o aporte de recursos por um fundo de investimento quando a administração recorre ao aumento de capital mediante subscrição de ações.

Concluídas as rodadas de negociação entre a companhia e o fundo de investimento, por exemplo, é possível que ainda que as partes concordem com todos os termos e condições para a entrada do investidor na sociedade, porém, na data do fechamento estipulada para o negócio, a sociedade que receberá os recursos não dispõe dos dados atuais para uma avaliação econômico-contábil da companhia. Isso porque a coleta dessas informações são sempre posteriores à ocorrência dos fatos contábeis. Assim, no momento estabelecido como o fechamento do contrato, a companhia não dispõe das informações de seu balanço contábil que represente com precisão o valor atual da sociedade cuja participação do fundo de investimento foi negociada.

Assim, as partes redigem o contrato de investimento com base em valores provisórios que, posteriormente à apuração, poderão sofrer alteração em relação ao número de ações que o investimento corresponde, considerando que os números que serão apresentados posteriormente.

Para fazer esse ajuste de participação após a obtenção das informações contábeis relativas à data da conclusão do contrato, são emitidos bônus de subscrição, os quais são titularizados pelo fundo de investimento e seu preço de exercício fixado em $\mathrm{R} \$ 1,00$, condicionado à alteração do valor econômico da companhia pela apuração posterior.

Se apurado posteriormente que o número de ações subscritas foi insuficiente para remunerar o aporte realizado pelo investidor - com base nas informações contábeis completas, devidamente apuradas até a data convencionada - este terá o direito de subscrever ações até o limite em que seja alcançado o equilíbrio da participação acionária correspondente ao valor final da companhia.

Consequentemente, o bônus de subscrição emitido nessas circunstâncias não tem a finalidade de capitalizar a sociedade, mas atua como instrumento de diluição, na hipótese de ser apurado posteriormente que a companhia valia menos do que foi recebido em ações. Por meio deste mecanismo, o fundo de investimento tem condições de preservar o valor do aporte de acordo com os valores efetivamos apurados referentes à data do fechamento e a companhia. 
Em outra hipótese semelhante, com a mesma finalidade de diluição, o bônus de subscrição pode ser usado em operação de aquisição de controle de companhia com o objetivo de equilibrar a participação do adquirente após o fechamento do negócio, caso posteriormente seja revelado passivo superior ao detectado até a celebração do contrato de compra e venda de ações. Isso se deve ao fato de que, antes de fechar o negócio, o comprador tem acesso limitado às informações financeiras da companhia e, não raro na prática societária, após o fechamento da operação, em auditorias realizadas ulteriormente podem ser identificados passivos significativos que não haviam sido contabilizados na formação do preço de aquisição.

Desse modo, o bônus de subscrição é emitido e o seu exercício condicionado à alteração de determinadas circunstâncias do negócio, tais como a hipótese levantada em nosso exemplo: a identificação de passivos desconhecidos à época da due dilligence realizada antes da conclusão do contrato de aquisição o controle da companhia. Para que o equilíbrio entre o valor da aquisição e o número de ações recebidas seja alcançado, o novo acionista controlador recebe bônus de subscrição cujo preço de subscrição das ações é fixado em um patamar menor do que aqueles indicados no art. 170, $§ 1^{\circ}$. Caso contrário, não seria atingido o propósito para o qual foram emitidos os títulos em questão.

Essa forma de utilização do bônus de subscrição também faz parte da prática das companhias compostas por acionistas com funções bem definidas na sociedade, os "investidores" e os "empreendedores". Não obstante tanto um como outro aportarem recursos à sociedade, e nesse aspecto, serem ambos investidores, com base no número de ações que dispõem e com os objetivos que possuem em relação à sociedade, cada acionista acaba desempenhando um perfil específico. O acionista investidor é aquele que detém participação menos representativa em termos de poder de controle da sociedade. Seus objetivos redundam, em grande parte, em estratégias para o aumento do preço das ações e farta distribuição de dividendos. O perfil do acionista empreendedor, por outro lado, está relacionado à idéia de exercer o poder de controle e conduzir os negócios sociais da forma que entende mais apropriada ${ }^{279}$.

Nessa hipótese, a companhia é formada com base na premissa de que o acionista investidor deve cumprir com um cronograma de investimento estabelecido em acordo de acionistas (art. 118). Nesse documento, os acionistas de perfil investidor e empreendedor

${ }^{279}$ ABBUD, André de Albuquerque Cavalcanti. O Acordo de Acionistas e a sua Execução Específica. In: CARMONA, Carlos Alberto; AMENDOEIRA JUNIOR, Sidnei (coords.). Direito, Gestão e Prática: Estratégias Processuais na Advocacia Empresarial, São Paulo: Saraiva, 2011, p. 97. 
definem as regras para exercício do voto e compra e venda de ações, bem como metas de investimento e as condições para a sua realização.

Para prevenir conflitos, os acionistas emitem bônus de subscrição que possibilitarão aos acionistas empreendedores (não sujeitos às metas de investimento) diluírem a participação do acionista investidor em caso de descumprimento dos objetivos traçados no acordo de acionistas. Assim, para operacionalizar a diluição, são atribuídos bônus de subscrição aos acionistas não sujeitos às metas contendo cláusula suspensiva que limita o exercício do título de acordo com o cumprimento das metas do acionista investidor. Caso as exigências convencionadas sejam atendidas pelo acionista investidor, o bônus de subscrição não poderá ser exercido. Da mesma forma que nos exemplos anteriores, o direito de subscrever as ações a que dão direito o bônus de subscrição não é absoluto e o preço de subscrição das ações é fixado abaixo dos critérios estabelecidos pela lei acionária.

Em todas essas situações, portanto, o bônus de subscrição é emitido com o objetivo claro de provocar a diluição de determinado acionista ou grupo de acionistas mediante cláusulas que condicionam o exercício do título a circunstâncias específicas. Esses casos levantam importantes questionamentos sobre a legitimidade do bônus de subscrição emitido com tais características. Por exemplo, cabe indagar a possibilidade de cláusula de ajustamento conter previsão que impeça o exercício do próprio título quando não verificadas determinadas condições (por exemplo, a alteração do valor da companhia na apuração de seu balanço contábil referente à data do fechamento do contrato de investimento). E, ainda, se é possível a fixação do preço de subscrição das ações abaixo dos patamares estabelecidos pela lei de sociedades anônimas.

Em todos os casos descritos acima, os bônus de subscrição com o objetivo de provocar a diluição de acionistas são emitidos por companhias fechadas, cuja regulamentação é menos intensa e cujos efeitos sobre o mercado de capitais são limitados, na medida em que seus valores mobiliários não são negociados publicamente.

A primeira questão a ser analisada é a compatibilidade do bônus de subscrição com a cláusula que condiciona o seu exercício a hipóteses não previstas em lei. Para responder a essa indagação deve-se considerar que o bônus de subscrição constitui um negócio jurídico emitido pela companhia de acordo com sua conveniência e o interesse social. Ademais, nos casos acima descritos, os títulos fazem parte da contratação entre acionistas, companhia e investidores. Isto é, sua atribuição decorre do acordo de vontades entre as partes implicadas no negócio. A sua titularização implica na aceitação de todos os seus termos, inclusive de cláusula suspensiva que restringe o exercício do direito de subscrição. 
Desse modo, se a emissão do bônus de subscrição é deliberada com base em acordo de vontade e suas condições são definidas justamente para ajustar uma situação de incerteza a respeito da participação acionária correspondente a um investimento ou metas de investimento contratadas no interesse da companhia, entendemos lícita a restrição do direito potestativo de que dispõe o titular do bônus de subscrição.

Podemos argumentar ainda que, com base na própria sistemática do bônus de subscrição, a escolha por subscrever ações apresenta naturalmente limitações de ordem econômica, porquanto no seu uso comum só haverá o exercício se o preço de subscrição da ação definido no título for menor que o preço da ação calculado de acordo com os elementos econômicos e financeiros contemporâneos à data do exercício ou frente ao seu valor de mercado.

Nos casos descritos anteriormente, mesmo tratando-se de restrições jurídica (não econômica), tais limitações operam sobre direito disponível e, nessa condição, tendo sido aceitas pelo titular quando adquiriu o direito de subscrever ações, não verificamos contrariedade ao direito. Em outras palavras, a subscrição de ações oportunizada pelo bônus tem natureza contratual, sendo lícito à companhia ofertante estabelecer condições para sua efetivação, desde que fundamentado em interesse legítimo da companhia ${ }^{280}$.

De outro lado, há que se analisar a possibilidade de se fixar o preço para a subscrição de ações abaixo dos critérios estabelecidos no art. 170, $\$ 1^{\circ}$. A aplicabilidade deste dispositivo na definição do preço de subscrição de ações relativas ao bônus de subscrição já foi examinada no item 2.2.2.4 e tem por finalidade proteger os antigos acionistas contra a desvalorização injusta de sua posição acionária, porquanto esta lhe confere um referencial sobre o retorno de seu investimento (dividendos) e sobre o poder político exercido pelo direito de voto que suas ações lhe atribuem, além dos reflexos na formação de preços do mercado de capitais (quando se tratar de companhia aberta).

A fixação do valor das ações tem relação com o referencial proporcionado pelo capital social e, portanto, com as regras que visam protegê-lo. Assim, para analisar a possibilidade de se fixar o preço de subscrição das ações que compõem o capital social é fundamental entender qual a função dele como elemento da companhia e sua estrutura jurídica.

O capital social é a cifra indicada do estatuto social que representa a contribuição dos acionistas para a realização do objeto $\operatorname{social}^{281}$ e, no nosso sistema societário, tem

\footnotetext{
${ }^{280}$ EIZIRIK, Nelson. A Lei das S/A comentada, vol. II, p. 492
}

281 BORBA, José Edwaldo Tavares. Direito Societário, p. 239. 
como principais funções externas (i) atuar como garantia indireta para credores (a garantia direta é proporcionada pelos ativos, bens e direitos detidos pela sociedade), (ii) de socialização ou democratização, pois a sua divisão em ações permite a dispersão em um grande número de pessoas da contribuição necessária para realizar o empreendimento social e também (iii) de avaliação econômica, pois é a partir da cifra do capital que se verifica se a sociedade auferiu lucros em função da diferença entre o valor do ativo e do passivo que superar o montante definido do capital social ${ }^{282}$.

Internamente, o capital social assume o papel de atribuição da qualidade de sócio, de organização e de referencial de direitos políticos e patrimoniais, essencial para estabelecer a medida de poder dos acionistas na sociedade. Para que o capital exerça todas essas funções, a lei acionária estabelece um conjunto de regras relacionadas à formação (artigos $5^{\circ}$ ao 10), aumento (artigos 166 e seguintes) e redução (art. 173 e seguintes) do capital social, assim como normas que determinam a criação da reserva legal (art. 193), limitam a distribuição de dividendos (art. 201), entre outras. Essas normas tem como principal objetivo proteger credores e acionistas da companhia ${ }^{283}$.

Como foi mencionado, a cifra do capital social não representa o valor da companhia, consiste apenas em uma medida de referência que baliza a participação dos acionistas, os quais, por sua vez, atuam na sociedade de acordo com sua representação social. Por isso, em regra geral, a subscrição de ações em valor inferior à avaliação econômica da companhia significa lesar os demais acionistas que não acompanharam o aumento de capital por meio da diluição de sua participação e premiar injustamente os subscritores que pagarão menos do que a ação vale. Consequentemente, os novos acionistas repartirão de modo privilegiado os resultados da companhia com os antigos acionistas que não acompanharam o aumento de capital.

$\mathrm{O}$ art. $170, \S 1^{\circ}$ representa o princípio de que a ação deve ser emitida pelo valor econômico e não pelo nominal. Para Valladão e Adamek, essas regras para determinação do preço das ações são cogentes e, se não atendidas, acarretam um aumento de capital abusivo $^{284}$. Contudo, não é possível conferir a esses critérios de determinação do preço de

\footnotetext{
${ }^{282}$ VALLADÃO, Erasmo Azevedo e Novaes França; ADAMEK, Marcelo Vieira von. Da Invalidade da Deliberação Assemblear Contrastante com as Regras de Fixação do Preço de Emissão de Ações (LSA, Art. 170, $1^{\circ}$ ). In: Revista de Direito Mercantil, Industrial, Econômico e Financeiro, n. 161/162, ano LI (nova série), jan./ago., São Paulo: Malheiros, 2012, p. 18.

${ }^{283}$ PINTO JUNIOR, Mario Englert. A capitalização da companhia, p. 260.

${ }^{284}$ Para Valladão e Adamek, o aumento praticado em desconformidade com as regras de determinação do preço de subscrição de ações será abusivo com base no sistema do direito societário de proteção da minoria: "em realidade, mais do que proteger a minoria, o que se deve é coibir abusos, provenham eles da maioria ou da minoria, pouco importa, de maneira realmente eficaz, pois só assim se estará realmente prestigiando a
} 
subscrição de ações a presunção, contrario sensu, de que, se seguidos, legitimariam o aumento de capital.

Consoante demonstraremos a seguir, as variáveis estabelecidas pela lei acionária não são sempre adequadas como de parâmetros para toda e qualquer operação de aumento de capital por subscrição de ações. Por exemplo, no caso de companhia que está enfrentando uma crise econômica e apresenta situação patrimonial negativa, quando suas ações tem negociação apenas de forma esporádica, as referidas balizas legais não servem de base para um preço de subscrição legítimo. Em decorrência de uma conjuntura financeiramente crítica, cuja perspectiva de rentabilidade e patrimônio líquido são negativos, não é possível obrigar a companhia a utilizar esses critérios para definir o preço de subscrição de suas ações em aumento de capital, sob pena da ação apresentar valor negativo. Nessas circunstâncias, forçosamente os critérios legais não funcionam, nem garantem um preço de subscrição adequado.

Essa hipótese foi extraída do Processo Administrativo Sancionador CVM no RJ 2005/5132 julgado pela Comissão de Valores Mobiliários em 22 de agosto de 2006. Nesse caso, foi examinada uma operação de aumento de capital subscrita pelos diretores da companhia, em cuja proposta não foram apresentadas as "justificativas pormenorizadas dos aspectos econômicos que determinaram o preço de emissão de $\mathrm{R} \$ 0,01$ (um centavo) por lote de mil ações". Por maioria, o órgão colegiado da autarquia aplicou a pena de advertência aos diretores por infração ao artigo 170, $\S 3^{\circ}$, da Lei ${ }^{\circ} 6.404 / 76$, tendo em vista a inviabilidade de aplicação dos critérios legais para determinação do preço de subscrição de ações, seja porque não era possível extrair um valor adequado a partir da baixa negociação das ações no mercado, seja por causa do patrimônio líquido negativo ou da perspectiva de rentabilidade da companhia também ser negativa ${ }^{285}$.

colaboração e a cooperação ínsitas ao fenômeno associativo", cf. VALLADÃO, Erasmo Azevedo e Novaes França; ADAMEK, Marcelo Vieira von. Da Invalidade da Deliberação Assemblear Contrastante com as Regras de Fixação do Preço de Emissão de Ações (LSA, Art. 170, §1), p. 34.

${ }_{285}$ De acordo com o voto do Diretor Relator: "Frise-se, a respeito da perspectiva de rentabilidade, que a conclusão do JP Morgan não contradiz o que já vinha dizendo a Companhia desde 2002 (fls. 257), pois em notas explicativas a suas demonstrações financeiras para 31.12.2001 já dizia que a Companhia "[vinha] sistematicamente incorrendo em prejuízos e apresentando capital de giro negativo, financiados por acionistas e por terceiros. De acordo com estimativas e projeções de sua Administração, esses prejuízos deverão ser absorvidos pelos resultados de operações futuras a partir do exercício de 2006" (grifos inexistentes no original, fls 257). Essa nota teria sido repetida nas demonstrações financeiras do exercício seguinte. Além disso, conforme se vê das demonstrações financeiras de 31.12.02, a Companhia tinha patrimônio líquido negativo em mais de quinhentos e um milhões de reais, mesmo com adiantamentos para futuros aumentos de capital no valor de quase seiscentos e setenta e cinco milhões de reais, uma vez que tinha prejuízos acumulados em pouco mais de quinhentos e um milhões de reais6. Enfim, parece realmente que não havia perspectiva de rentabilidade futura para a Companhia, sem que ela fosse saneada financeiramente”. Processo Administrativo Sancionador CVM No RJ2005/5132, julgado em 22/08/2006. 
A partir deste exemplo, objetivamos ilustrar o nosso argumento de que os critérios do art. $170, \S 1^{\circ}$ não dão conta de balizar toda e qualquer operação de aumento de capital que envolva subscrição de ações. Logo, se na emissão de bônus de subscrição é respeitado o princípio que dá sustentação aos critérios do art. $170, \S 1^{\circ}$ (no sentido preservar o valor da própria companhia) a incidência dessas regras gerais não pode ser exigidas nos casos hipotéticos narrados. Nesses casos, a aplicação dos parâmetros legais provocaria o efeito contrário ao pretendido pela lei.

Assim, entendemos apropriado que, em relação aos exemplos mencionados, o preço da ação decorrente do exercício do bônus de subscrição seja inferior aos ditos parâmetros, na medida em que não foi ofertado para investidores em geral, em situação privilegiada. A emissão, nesse caso, está atrelada e relacionada economicamente ao aporte realizado pelo investidor (ou adquirente de controle) à companhia. O equilíbrio da participação do novo acionista em relação à sua contribuição será alcançada apenas com a adequação do valor da ação que foi integralizada em desacordo com os dados contábeis definitivos de avaliação da companhia apurados posteriormente.

Assim, a fixação do preço de subscrição da ação em valor abaixo ao que corresponderia se utilizados os parâmetros legais não se mostra ilegítimo, pois considerando todo o contexto e elementos da operação de investimento em conjunto com a emissão de bônus de subscrição, o valor econômico da ação - objetivo das balizas indicadas no art. $170, \S 1^{\circ}$ - estaria sendo respeitado.

Outra hipótese que pode ser mencionada para ilustrar o nosso ponto de vista é a do preço da ação em oferta inicial de ações, modalidade de subscrição pública que representa a abertura do capital da sociedade anônima. Nessa situação, considerando o impacto importante que a cotação das ações representa para a companhia nesse primeiro passo no mercado de capitais, algumas estratégias são utilizadas no procedimento de IPO (initial public offer) com o objetivo de dar sustentação ao preço de subscrição fixado na operação. Uma dessas estratégias é a de estabelecer o preço de subscrição um pouco abaixo do preço construído pelo bookbuilding ${ }^{286}$, por aproximação em relação a outras companhias do mesmo setor e pelo sistema de fluxo de caixa descontado, com o objetivo de que reste uma demanda por subscrição das ações não atendida na distribuição no mercado primário, forçando os interessados que não conseguiram subscrever ações a fazê-lo por meio de aquisição no mercado secundário ${ }^{287}$. Essa técnica tem como objetivo evitar que o preço das

\footnotetext{
${ }^{286}$ Vide item 2.2.2.4. do Capítulo 2.

${ }^{287}$ PINTO JUNIOR, Mario Englert. A capitalização da companhia, p. 276.
} 
ações despenque imediatamente após o IPO e manter o valor do papel nas negociações posteriores.

Conclui-se, portanto, que a prática descrita acima não atende de forma rigorosa as regras para determinação do preço de subscrição de ações apresentadas no art. $170, \S 1^{\circ}$, que exige a fixação de acordo com a perspectiva de rentabilidade da companhia ou valor patrimonial líquido da ação (não sendo possível, nesse caso, a utilização da cotação por se tratar de oferta inicial). Não obstante, a fixação do preço das ações em valor abaixo dos critérios legais possui forte fundamentação no próprio interesse da companhia e de seus acionistas. Em que pese, no curto prazo, interessar-lhes permitir a subscrição pelo maior preço que o mercado possa pagar; no longo prazo, a vantagem de manter a cotação das ações após a entrada para a bolsa de valores ou mercado de balcão tem importância ainda maior do que o receber um aporte maior de recursos para capitalização imediata da companhia.

Assim, entendemos ser razoável sustentar que o valor de subscrição de ações com o desconto em oferta inicial de ações também constitui uma flexibilização da regra contida no art. $170, \S 1^{\circ}$, o que nos leva a aplicar a mesma racionalidade ao caso de emissão de bônus de subscrição em companhia fechada cuja subscrição de ações ocorre fora do mercado de capitais. O objetivo não é oferecer vantagem ao titular do bônus de subscrição sem correspondência com o valor da companhia, mas justamente adequar a participação do titular à realidade financeira da sociedade a posteriori, em ocasiões em que, no fechamento do negócio, as partes envolvidas no aumento de capital não dispunham das informações necessárias para o cálculo definitivo.

Ademais, tratando-se de companhia fechada, cuja participação acionária é pertinente à organização interna da sociedade, econômica e politicamente (não constituindo ofensa a sua função de garantia externa perante credores, por se tratar de aumento de capital), a regulamentação sobre o preço de suas ações pelos parâmetros da lei deve ser relativizada, especialmente considerando que a operação abrange companhia fechada, cujo preço das ações não reflete na negociação de ações no mercado de capitais.

Por outro lado, se a utilização do bônus de subscrição nessas condições excepcionais guarda somente a intenção de diluir o antigo acionista (sem que seja preservado o valor econômico da participação acionária) ou faticamente excluir a minoria indesejada, sem que a emissão dos títulos esteja ancorada em operação idônea e justificada, a regra do art. $170, \S 1^{\circ}$ deve se impor e a aprovação da emissão pode ser configurada como 
abusiva, podendo gerar a invalidade da deliberação com base na regra do art. $115^{288}$, a qual determina que o voto deve ser exercitado pelos acionistas no interesse da companhia, podendo nesse caso ser aplicado a operação lesiva ao sócio e não apenas à companhia ${ }^{289}$.

Por fim, cabe acrescentar que, em decisão proferida por ocasião do REsp 1.190.755/RJ, julgado em 01 de agosto de 2011, prevaleceu no Superior Tribunal de Justiça o entendimento de que a norma contida no art. $170, \S 1^{\circ}$ não tem caráter cogente. Segundo o julgado, não há invalidade da deliberação que fixou o preço de subscrição das ações em patamar inferior, até porque o próprio dispositivo não estabeleceu tal conseqüência jurídica ${ }^{290}$.

Entendemos que a emissão de bônus de subscrição com o objetivo de diluir a participação acionária, portanto, é admitida no direito pátrio. Não obstante, deve ter justificativa na própria racionalidade da operação, como aquelas apontadas anteriormente, que dizem respeito à composição do equilíbrio da participação acionária.

Não atendendo a interesse legítimo da companhia, a subscrição de ações por preço inferior aos critérios legais pode redundar em hipótese de abuso do poder de controle, e na conseqüente responsabilização dos membros do conselho de administração. A licitude e adequação do aumento de capital com emissão de bônus de subscrição mediante preço de exercício abaixo dos parâmetros legais deverão ser verificadas caso a caso, considerando que tais operações não são neutras do ponto de vista do interesse dos sócios. Conforme referimos quando tratamos de diluição injustificada, a fixação do preço em patamar inferior afeta potencialmente as posições jurídicas dos antigos acionistas, pois se permite a entrada de terceiros ou o aumento da participação de um acionista sem que seja pago o real

\footnotetext{
${ }^{288}$ Art. 115. O acionista deve exercer o direito a voto no interesse da companhia; considerar-se-á abusivo o voto exercido com o fim de causar dano à companhia ou a outros acionistas, ou de obter, para si ou para outrem, vantagem a que não faz jus e de que resulte, ou possa resultar, prejuízo para a companhia ou para outros acionistas.

${ }^{289}$ No entendimento de Valladão e Adamek, o art. 115 da lei de sociedades anônimas estatui o dever societário da lealdade e, portanto, é aplicável também ao acionista prejudicado e não somente em relação à companhia, cf. VALLADÃO, Erasmo Azevedo e Novaes França; ADAMEK, Marcelo Vieira von. Da Invalidade da Deliberação Assemblear Contrastante com as Regras de Fixação do Preço de Emissão de Ações (LSA, Art. 170, $\S 1^{\circ}$ ), p. 24.

${ }^{290}$ Direito Societário. Aumento de capital de sociedade anônima. Emissão de novas ações. Diluição da participação acionária de minoritários. Preço das ações. Fixação. Balizas previstas no art. 170, §1 ${ }^{\circ}$, da LSA. Norma não cogente de cujo distanciamento, se verificado, não enseja a anulação dos atos deliberativos. eventual violação que se resolvem perdas e danos. $1 . \mathrm{O}$ art. $170, \S 1^{\circ}$, da LSA, não garante a equivalência na participação societária dos antigos acionistas, depois de se proceder ao aumento de capital, apenas impede a diluição injustificável dessa participação, geralmente, abuso de poder dos controladores. A equivalência da participação acionária é garantida pelo exercício do direto de preferência na aquisição dessas novas ações.

2. A norma insculpida no art. $170, \S 1^{\circ}$, da LSA não é cogente, por isso que a sua não observância na fixação do preço de emissão da ação ou a escolha de critério diferente, na hipótese de aumento de capital, não acoima o ato deliberativo de nulo, mesmo porque o dispositivo não prevê tal consequência. (...) 4. Recurso especial não provido.
} 
valor da companhia, reduzindo-se o valor da participação acionária dos demais acionistas e não apenas a proporção da participação detida pelos acionistas que não acompanharam o aumento de capital.

\section{Análise do caso da Ambev}

Neste ponto, para encerrar o capítulo sobre a prática societária do bônus de subscrição realizaremos uma breve análise do Processo CVM nº SP 2002/0474, o qual teve origem na Consulta formulada pela Companhia de Bebida das Américas - Ambev. Nessa consulta, a companhia pretendia a confirmação perante a autarquia acerca da exatidão do preço de exercício do bônus de subscrição, tendo em vista que, na deliberação assemblear que determinou a emissão do título, estava prevista cláusula de ajustamento que balizava o preço para subscrição de ações em caso de "subscrição pública ou particular de ações"291, devendo ser adotado o menor preço praticado. Considerando que entre a emissão do bônus de subscrição e o seu exercício houve a subscrição de ações decorrentes de plano de opção de compra de ações outorgados a administradores e empregados com preço inferior ao previsto para o exercício do bônus de subscrição, os titulares desse título pretendiam exercer seu direito com base no preço mais favorável ${ }^{292}$.

Assim, a Consulta da Ambev pretendia que a Comissão de Valores Mobiliários se manifestasse sobre a não interferência na formação do preço de exercício de bônus de subscrição em decorrência do preço das ações subscritas no âmbito de plano de opção de compra de ações destinado a administradores. Segundo o parecer firmado pelo Dr. Paulo Cezar Aragão anexado à Consulta apresentada pela Ambev, o volume de recursos advindos do exercício da opção de compra de ações não é compatível com a finalidade de aumento de capital do bônus de subscrição, a qual se destina à capitalização da empresa ${ }^{293}$. Por essa razão, os critérios para fixação do preço de ação em plano de opção não poderia ser aplicado para as ações subscritas por força do bônus.

\footnotetext{
291 A redação da cláusula de ajustamento é a seguinte: “caso sejam efetuados aumentos de capital por subscrição privada ou pública até o término do prazo para o exercício do direito à subscrição, aumentos esses nos quais o preço de subscrição venha ser inferior ao valor ajustado para o exercício de subscrição com base nos bônus, o preço de subscrição destas ações será ajustado para igualar o preço de emissão e todas as correções e ajustes subsequentes partirão desse novo patamar".

${ }^{292}$ No caso concreto, o preço para subscrição de ações em decorrência do exercício da opção de compra não poderia ser inferior a $90 \%$ valor médio da cotação (com base nos últimos 3 pregões) das ações de emissão da companhia em bolsa de valores no momento da outorga da opção.

${ }^{293}$ Cf. p. 9 dos autos do Processo CVM no SP 2002/0474.
} 
Desse modo, ressalta o pareceirista que há discrepância entre o preço estabelecido para finalidade da opção de compra e do bônus, considerando também o valor de mercado das ações. O preço inferior ao de mercado - autorizado para exercício da opção - acarreta diluição que se justifica em função do trabalho desempenhado por colaboradores da empresa. Esse não é o caso do bônus de subscrição, cuja emissão foi direcionada a pessoas externas à companhia. Por fim, o parecer procurou diferenciar o bônus de subscrição da opção de compra com base na distinção estabelecida pela lei quando excluiu para o segundo o direito de preferência (art. 171, $3^{\circ}$ ). E, com base nessas disparidades, afirmava que não poderia ser adotado o preço de exercício da opção para o bônus de subscrição.

Em memorando, a Subprocuradoria Jurídica da Comissão de Valores Mobiliários ${ }^{294}$ manifestou-se no sentido de que o exercício da opção de compra promove um aumento de capital por subscrição privada, o qual, de acordo com os termos da emissão do bônus de subscrição, se enquadrava na hipótese prevista para ajuste do preço de exercício do referido título. Isso porque a lei não deu tratamento distinto à subscrição de ações decorrente do exercício do bônus de subscrição em relação à subscrição resultante do exercício de opção de compra. Ademais, de acordo com a mencionada Subprocuradoria, não houve, por parte da companhia, ressalva ou especificação que autorizasse interpretação diversa quanto à natureza da subscrição privada, de modo que deve prevalecer o entendimento de que a alteração do preço de exercício do bônus de subscrição deve ocorre em qualquer aumento de capital por subscrição de ações.

Manifestando-se sobre a opinião da referida Subprocuradoria Jurídica, a AmBev ressaltou a natureza especial da subscrição provocada pelo exercício da opção de compra e que exercício desta não poderia ser considerado em sua essência um aumento de capital, considerando que a emissão de novas ações objetivaria apenas cumprir obrigação para com os titulares das opções. Além disso, segundo a companhia, o favorecimento dos titulares de opções em decorrência do preço de exercício privilegiado não deveria ser estendido aos titulares do bônus, os quais não contribuem para o êxito da sociedade da mesma forma que administradores e empregados que titularizam a opção. Caso esse entendimento não prevalecesse, haveria penalização dos acionistas minoritários em virtude do ingresso de novos acionistas com o aporte de recursos em montante inferior ao valor da companhia, causando diluição injustificada.

${ }^{294}$ Cf. MEMO/CVM/GJU-2/No271/02, juntado às páginas 25-26 dos autos do Processo CVM nº SP 2002/0474. 
Rejeitada a manifestação da Ambev pela Subprocuradoria Jurídica em razão daquela manifestação não comportar recurso ou reexame pela Procuradoria, foi determinada a distribuição do processo a diretor da Autarquia para relatar a questão.

Por ocasião da apresentação de Recurso pela Ambev, foi juntado aos autos do processo administrativo Parecer do Dr. José Luiz Bulhões Pedreira, no qual foi salientado que a questão deve ser analisada considerando a função econômica do negócio jurídico, sua regulação legal e todas as demais circunstâncias. Para ele, a disciplina legal dos aumentos de capital da companhia não tem como gênero 'aumento por subscrição pública ou privada'. Esta caracterização é essencialmente distinta daquela promovida pela 'opção de compra de ações'.

Segundo Bulhões Pedreira, há 3 tipos de aumento de capital, na medida em que pode ser efetivado por (i) de capitalização de reservas e lucros; (ii) por conversão debêntures, partes beneficiárias (novação direito de crédito), opções e bônus (exercício direito de participação societária) e (iii) subscrição pública ou particular. Esta última espécie foi a escolhida pela assembleia geral da AmBev. Somente esta, portanto, poderia alterar o preço de emissão do bônus de subscrição. Em sua opinião, se a companhia tivesse interesse em estender a garantia antidiluição às ações resultantes do exercício da opção de compra, deveria declará-lo de forma expressa. Com base nesses argumentos, concluiu que não poderia ser estendida aos titulares de bônus a vantagem de preço conferida a administradores e empregados, equiparando situações jurídicas distintas e provocando, por isso, a diluição injustificada dos acionistas que não adquiriram bônus de subscrição ${ }^{295}$.

No Parecer Francisco da Costa e Silva, também juntado aos autos do processo ora analisado pela Ambev, foi abordada a finalidade da regra de ajuste do preço do bônus de subscrição no sentido de assegurar um preço de exercício compatível com o valor justo da ação nele referenciada ${ }^{296}$. A opção de compra não poderia servir de referência para o ajustamento do preço de exercício do bônus de subscrição, por suas características incompatíveis com este, tais como, a inaplicabilidade do direito de preferência, o seu desprendimento das normas que estabelecem critérios de fixação do preço de emissão de ações. Isso porque, enquanto a regra vigente privilegia a noção de valor econômico (perspectiva de rentabilidade, valor patrimonial, cotação em mercado), nas opções é possível estabelecer um valor menor que o "preço justo", em virtude de sua finalidade de premiar os beneficiários pelos serviços prestados à companhia.

${ }^{295}$ Cf. Processo CVM no SP 2002/0474, p. 103.
${ }^{296}$ Cf. Processo CVM no SP 2002/0474, p. 106 e seguintes. 
O parecerista conclui que o aumento de capital que não se sujeita às regras do direito de preferência e de fixação do preço de emissão sem diluição injustificada não está inserido no regime geral dos aumentos de capital e, portanto, não poderia influenciar o preço dos bônus de subscrição ${ }^{297}$. Segundo ele, uma interpretação excessivamente abrangente em sentido contrário implicaria em prejuízo a terceiros e acionistas, que não integram a relação entre companhia e subscritores de bônus.

Outros pareceres de renomados juristas foram apresentados pela companhia apresentando fundamentos para sustentar o entendimento da Ambev na consulta apresentada, salientando as diferenças entre o regime jurídico do bônus de subscrição e da opção de compra de ações, cujos respectivos exercícios não poderiam ser tomadas como situações jurídicas idênticas.

Posteriormente, titulares do bônus de subscrição ${ }^{298}$ apresentaram requerimento postulando a "adoção de providências acautelatórias e coercitivas e apuração de responsabilidade dos administradores" da Ambev. Em sua petição, argumentaram pela possibilidade de equiparação do preço de subscrição das ações decorrentes do exercício de bônus de subscrição ao preço das ações subscritas em virtude de plano de opção de compra de ações $^{299}$.

Em sede de memorais, os referidos titulares, manifestaram-se contra a pretensão da companhia representada pela Consulta por entenderem que a Comissão de Valores Mobiliários deve assegurar o direito dos investidores de exercerem a subscrição de ações com base na cláusula de ajustamento que lhes resguardava contra preços de subscrição inferiores quando da realização de aumentos de capital.

Para sustentar sua posição, juntaram ao processo Parecer dos juristas Modesto Carvalhosa e Nelson Eizirik, os quais analisaram o bônus de subscrição sob a ótica de sua natureza jurídica de título de crédito. De acordo com os pareceristas, o título de crédito confere ao seu titular o direito de exigir a prestação do devedor nele especificado, amparado pelos critérios da autonomia e da literalidade, elementos essenciais a essa categoria jurídica.

\footnotetext{
${ }^{297}$ Cf. Processo CVM n ${ }^{\circ}$ SP 2002/0474, p. 123: "não parece haver campo para que se permita a inclusão, nas condições de ajuste do preço de subscrição contido no bônus de subscrição da AmBev, dos aumentos de capital decorrentes do exercício do plano de opção de compra de ações, eis que, caso contrário, tal condição representaria verdadeira afronta à lei societária, principalmente no que pertine à proteção dos acionistas da companhia contra a diluição injustificada de sua participação no capital social."

${ }^{298}$ Banco de Investimentos Credit Suisse First Boston S/A, Credit Suisse First Boston Garantia Próprio Fundo de Investimentos em Ações, Brasil Fixed Income Investments (Netherlands) B.V. e Credit Suisse First Boston Equity Investments (Netherlands) B.V.

${ }^{299}$ Cf. Processo CVM no SP 2002/0474, p. 271.
} 
Em virtude da característica da literalidade que o bônus de subscrição deve apresentar, consoante Carvalhosa e Eizirik, as condições para o exercício do direito devem constar de forma expressa na deliberação que aprovou a sua emissão. Por essa razão, não se aplicam os princípios interpretativos de negócios jurídicos bilaterais, na medida em que estes pressupõem a existência de relação direta entre as partes. De acordo com os pareceristas, a interpretação das condições e dos termos para o exercício do direito contido no bônus de subscrição é literal, não podendo o significado das disposições que regulam o seu exercício ser restringido ou estendido.

Ainda de acordo com o mencionado parecer, a subscrição de ações decorrente da opção de compra de ações é abrangida pela cláusula de ajustamento prevista na emissão do bônus de subscrição, tendo em vista atender aos requisitos do conceito jurídico de aumento de capital por subscrição privada. Além disso, a subscrição de ações tem natureza de contrato de adesão, em virtude da oferta representada pelo bônus de subscrição. Consequentemente, suas estipulações devem ser interpretadas de forma mais favorável ao aderente, nos termos do art. 423 do Código Civil.

Em outro parecer juntado por titulares de bônus de subscrição, elaborado pelo Dr. Calixto Salomão Filho, foi considerado, com base na lei, que não há diferença entre o aumento de capital promovido por bônus de subscrição e aquele realizado em decorrência do exercício de opções de compra, porquanto as características que os distinguem não servem para impedir a aplicação do preço de exercício de um em relação à subscrição de ações decorrentes do outro.

Em resposta às manifestações da companhia e dos titulares de bônus de subscrição, a Gerência de Estudos Econômicos da Comissão de Valores Mobiliários apresentou opinião favorável à companhia concordando com a tese de que a subscrição de ações decorrentes de plano de opção tem caráter sui generis em virtude de não estar adstrito à regra antidiluição (art. 170, $\$ 1^{\circ}$ ), bem como por ser considerado um incentivo à performance e retenção de profissionais pela empresa. Outrossim, sob a ótica econômica, foi considerada incorreta a utilização das subscrições no âmbito do plano de opção de compra para o ajuste do preço de subscrição do bônus. Esse entendimento foi construído com base nos relatórios de concentração fornecidos pela BM\&FBOVESPA relativamente à negociação dos bônus no mercado secundário, os quais apontaram que entre 4 e 7 comitentes concentravam $75 \%$ ou mais da quantidade negociada no mercado à vista dos dois tipos de bônus da Ambev, a cada semestre. 
Por esse motivo, concluiu a Gerência de Estudos Econômicos que não estava correta a opinião manifestada no Parecer Técnico elaborado por José Luiz Osorio de Almeida Filho (juntado ao processo a pedido de outra titular de bônus de subscrição, a Tempo Capital Fundo de Investimento em Ações) de que a negociação do título representava "a interpretação mercado financeiro" sobre o preço de subscrição dos bônus no patamar de preço da opção de compra. De acordo com a mencionada área técnica da Comissão de Valores Mobiliários, a concentração do bônus de subscrição em poucos titulares sugere um mercado restrito de negociação, não se podendo dar a abrangência pretendida no Parecer Técnico apresentados pela titular de bônus.

De forma bastante resumida, esses foram os principais fundamentos trazidos à discussão pela Ambev, pelos titulares de bônus de subscrição e pelo corpo técnico da Comissão de Valores Mobiliários. Com base nas opiniões apresentadas no processo, foi decidido pelo órgão colegiado da autarquia, em julgamento por maioria ${ }^{300}$, que não deveria ser incluído, na determinação do preço de exercício do bônus de subscrição, o preço de subscrição das ações relacionadas ao plano de opção de compra de ações destinado a administradores e empregados da companhia.

De acordo com o voto da diretora relatora, o preço de ações subscritas por ocasião do plano de opções de compra destinado a administradores e empregados da Ambev não deveria influir na determinação do preço de exercício do bônus de subscrição, na medida em que, na expressão contida na cláusula de ajustamento do referido título ("aumentos de capital por subscrição privada ou pública") não abrangeria o aumento de capital decorrente de opção de compra de ações, da mesma forma que não deveria assimilar o preço relativo a conversão em ações de debêntures ou partes beneficiárias ou aumento de capital). Para que o preço de exercício da opção de compra fosse considerado no aumento de capital previsto na cláusula antidiluição, essa circunstância deveria ser expressa. Por fim, argumentava a diretora que dar o mesmo tratamento a titulares de bônus e de opções de compra importaria em quebra da igualdade econômica e jurídica desejadas.

De acordo com o voto vencedor, não tendo o bônus de subscrição e a opção de compra de ações a mesma natureza, as subscrições decorrentes do aumento de capital que estes títulos ensejam não podem ser equiparados para fins de aplicação da cláusula de

\footnotetext{
300 Conforme Ata da Reunião Extraordinária do Colegiado da CVM de 31.03.2003, o Diretor Wladimir Castelo Branco acompanhou o voto vencedor apresentado pela Diretora-Relatora Norma Parente, que considerou que não deve ser incluído na determinação do preço de exercício dos bônus de subscrição o preço de emissão de novas ações oriundas do plano de opção de compra de ações da AmBev. A Diretora Substituta Ana Maria França acompanhou a manifestação da SEP e da PJU.
} 
ajuste. Nas palavras da relatora, pode-se "igualar coisas que possuem a mesma natureza, ou seja, não se pode igualar coisas desiguais que não possuam os mesmos direitos”. Ademais, considerando que o objetivo da cláusula de ajustamento é precisamente equalizar o preço de subscrição à nova realidade econômico-financeira da companhia e guardar a paridade das ações, sustentou a diretora que a extensão da cláusula de ajuste somente poderia se dar diante de valores mobiliários que atribuem a seus titulares os mesmos direitos, o que não se verifica entre bônus de subscrição e opções de compra destinada a administradores e empregados, que implicam diversas restrições aos seus titulares.

Com esta decisão, foi encerrada a esfera administrativa, motivo pelo qual os titulares de bônus de subscrição submeteram a controvérsia ao Poder Judiciário com o objetivo de reverter o posicionamento adotado pela Comissão de Valores Mobiliários. A Romanche Investment Corporation LLC propôs, contra a companhia, ação ordinária visando o cumprimento de obrigação de fazer cumulada com indenização (Processo $\mathrm{n}^{\circ}$ 0047299-63.2003.8.19.0001 ${ }^{301}$ ), requerendo a condenação da companhia a emitir as ações ordinárias e preferenciais, o seu depósito e a declaração de que a cláusula de ajustamento do preço abrange os aumentos de capital verificados em relação ao exercício de plano de opção de compra de ações, reconhecendo-se o seu direito de subscrever as ações decorrentes do bônus de subscrição pelo mesmo preço. Postulou, ainda, a condenação da companhia emissora em perdas e danos, consistentes no pagamento de vantagens, dividendos e bonificações, no que tange às ações correspondentes na data em que deveriam ser emitidas (prazo do exercício) e a data em que forem efetivamente depositadas na instituição financeira correspondente.

Em sua defesa, a Ambev alegou que não houve aumentos de capital com subscrição pública ou privada após a emissão do bônus de subscrição capaz de fazer incidir a cláusula de ajustamento, tendo apenas ocorrido aumento de capital de natureza distinta com a finalidade de atender ao exercício de opções de compra de ações outorgadas a administradores e empregados. Apresentou ainda reconvenção, requerendo que a parte autora, titular de bônus de subscrição, realize o pagamento das ações sobre as quais manifestou interesse em subscrever com base no valor divulgado em Fato Relevante (datado de 04/11/2002), acrescidos de juros e correção monetária.

Em contestação à demanda de reconvenção, a titular de bônus de subscrição insurgiu-se contra o pedido da companhia alegando a impossibilidade de exigir o exercício

\footnotetext{
${ }^{301} \mathrm{O}$ mencionado processo tramitou perante a $4^{\mathrm{a}}$ Vara Empresarial do Foro Central da comarca do Rio de Janeiro, RJ, tendo sido distribuído em 29/04/2003.
} 
do bônus de subscrição com base em preço com o qual não concordou. Após instrução do feito, sobreveio sentença julgando improcedente o pedido da autora e julgou procedente a reconvenção proposta pela AmBev, ratificando a decisão do órgão colegiado da Comissão de Valores Mobiliários.

Irresignada com o desfecho processual, a investidora interpôs recurso de apelação, o qual contrarrazoado, foi julgado pela $3^{\text {a }}$ Câmara Cível do Tribunal de Justiça do Rio de Janeiro, revertendo a decisão de primeira instância. Por maioria, os desembargadores deram provimento ao recurso da titular de bônus de subscrição para reformar a sentença e julgar procedente a demanda principal e improcedente a reconvenção ${ }^{302}$.

Dentre os principais argumentos do acórdão, destaca-se o entendimento do juízo recursal acerca da ocorrência de aumentos de capital autorizadores da incidência da cláusula de ajuste, com base na perícia econômico contábil constante dos autos, demonstrando que os preços de subscrição das opções de compra foram inferiores ao valor determinado para o exercício do bônus de subscrição. Por considerar que não há distinção legal entre os aumentos de capital promovidos em virtude do exercício de opção de compra e a hipótese descrita na cláusula de ajuste do bônus de subscrição, concluiu-se no acórdão que é possível a aplicação do preço menor.

Diante do julgamento de provimento do recurso e a conseqüente procedência dos pedidos principais deduzidos pela autora e apelante, foi acolhido o pleito indenizatório para condenar a companhia ao pagamento de dividendos, bonificações e outros direitos decorrentes das ações desde a data em que deveriam ter sido emitidas. Consequentemente, foi julgada improcedente a reconvenção proposta pela companhia, tendo em vista a impossibilidade de se obrigar a titular do bônus à subscrição de ações por valor distinto daquele abrangido pela manifestação de vontade de exercitar o título. Portanto, foi considerado que a titular apenas se comprometeu em subscrever ações com o preço que entendia correto. Com base no parecer do Dr. José Carlos Barbosa Moreira, o relator entendeu que a manifestação de vontade não é cindível, de modo que o preço do exercício pertinente à sua declaração é parte integrante, não podendo a declaração de vontade ser interpretada da forma pretendida pela companhia.

Por fim, concluiu o desembargador relator que ocorreram "aumentos de capital autorizadores da incidência do disposto na cláusula de ajuste”, na medida em que a referida

302 Acórdão proferido nos autos do Processo no 0047299-63.2003.8.19.0001, disponível em http://www1.tjrj.jus.br/gedcacheweb/default.aspx?UZIP=1\&GEDID=00034C83EBCF88E8F45EB520F64F2 FB3CFA17E11C3534346, acessado em 12/11/2014. 
previsão não faz distinção entre aumentos por subscrição pública ou privada decorrente de plano de opção de compra de ações ou qualquer outra espécie.

Atualmente a questão tramita perante o Superior Tribunal de Justiça, através do Recurso Especial $n^{\circ} 1.348 .956^{303}$. Desde 15 de agosto de 2014, os autos encontram-se conclusos com o Ministro Relator Marco Buzzi para julgamento.

O Banco de Investimentos Credit Suisse First Boston S/A e outros ${ }^{304}$, por sua vez, demandaram a Ambev (Processo $\mathrm{n}^{\mathrm{o}}$ 9067761-22.2005.8.26.0000 ${ }^{305}$ ) visando fosse declarado o direto de exercerem a subscrição de ações da companhia, bem com a condenação desta a emitir ações decorrentes do exercício do referido título pelo menor preço por ação, conforme cláusula de ajustamento, acrescidos dos dividendos e consectários legais.

A Ambev apresentou reconvenção requerendo a condenação dos titulares de bônus de subscrição ao pagamento do preço que a companhia entende como correto para o exercício do título acrescidos dos juros de $12 \%$ ao ano e correção monetária. O pleito, entretanto, foi indeferido liminarmente sob o fundamento da impossibilidade jurídica do pedido, considerando que a pretensão dos titulares de bônus de subscrição, manifestada na ação principal, diz respeito ao direto de subscrever ações por preço favorecido e não a qualquer preço como pretende a companhia. Assim, mesmo que fosse julgada improcedente a demanda das titulares, não se imporia a procedência do pedido que objetiva obrigar a subscrição de ações a qualquer preço, com base nos requisitos relativos à compra e venda que exigem o consenso sobre a coisa e o preço, nos termos dos artigos 1122 e 1126 do Código Civil em vigor ao tempo da aquisição dos direitos de subscrição. Por não haver concordância acerca do preço das ações, não há possibilidade jurídica em acolher a pretensão da companhia.

Contra esta decisão na ação de reconvenção, a Ambev interpôs Agravo de Instrumento perante o Tribunal de Justiça de São Paulo, o qual foi desacolhido com fundamento na motivação exarada na decisão de primeiro grau. Opostos Embargos Declaratórios, que foram rejeitados pelo juízo colegiado, a companhia interpôs Recursos

\footnotetext{
${ }^{303}$ Inicialmente foi negado seguimento ao Recurso Especial interposto pela Ambev perante o TJRJ, motivo pelo qual a companhia interpôs o Agravo de Instrumento $\mathrm{n}^{\circ}$ 1.097.056 perante o STJ, o qual foi conhecido para dar parcial provimento ao recurso especial. Desta decisão, a Ambev apresentou Agravo Regimental, ao qual, por maioria, foi dado provimento e determinada a subida do recurso especial para melhor exame da controvérsia.

${ }^{304}$ Conjuntamente com Credit Suisse First Boston Garantia Próprio Fundo de Investimentos em Ações, Brasil Fixed Income Investments (Netherlands) B.V. e Credit Suisse First Boston Equity Investments (Netherlands) B.V.

${ }^{305}$ Este processo tramitou perante a $23^{a}$ Vara Cível do Foro Central Cível da comarca de São Paulo, SP.
} 
Especial e Extraordinário. Admitido apenas parcialmente o primeiro e autuado como REsp $n^{\circ}$ 717.327, este não foi conhecido pela Quarta Turma do Superior Tribunal de Justiça ante a verificação da ausência de titularidade do direito subjetivo pleiteado, tendo sido declarada a autora companhia de ação por ilegitimidade ativa ad causam, sem julgamento de mérito da demanda.

Opostos Embargos de Declararação contra o acórdão, estes foram rejeitados e a decisão transitou em julgado em 19/10/2006. Apenas poucos dias depois, sobreveio despacho do relator designado para o julgamento dos Recursos de Apelação interpostos pelas partes que tramitavam perante o Tribunal de Justiça de São Paulo (Processo $\mathrm{n}^{\circ}$ 9067761-22.2005.8.26.0000) homologando a desistência manifestada pelas partes das apelações interpostas nos autos da demanda principal.

Em resumo, prevaleceu perante o Poder Judiciário, até o momento, a tese defendida pelos titulares dos bônus de subscrição de que é aplicável a cláusula de ajustamento à subscrição de ações decorrente do título, por entenderem que a lei não faz distinção sobre a subscrição de ações decorrentes do exercício de opção de compra de ações destinada a administradores, empregados ou de bônus de subscrição. No caso concreto, entendeu-se que, caso as companhia desejasse excepcionar o aumento de capital provocado pela subscrição de açoes em plano de opções, deveria tê-lo feito expressamente.

Tampouco foi admitida a pretensão da companhia de obrigar os titulares de bônus de subscrição a exercerem o direito diante da manifestação de interesse declarado por meio da propositura de ação para exigir a emissão de ações. De acordo com os competentes julgadores tal demanda é obstada pela impossibilidade jurídica do pedido, diante da inadmissibilidade de se exigir o exercício de direito potestativo em relação ao qual não concordaram os titulares não concordaram com todos os seus termos, notadamente o preço de exercício, condição inafastável para considerar admitir o pleito da companhia. 


\section{CONCLUSÃO}

Ao longo do estudo aqui desenvolvido, traçamos os contornos do regime jurídico do bônus de subscrição com o objetivo de aprofundar a compreensão do instituto, o qual é pouco tratado na doutrina pátria.

A análise acerca da natureza jurídica do bônus de subscrição como valor mobiliário contribuiu para a compreensão do seu funcionamento como mecanismo de capitalização das sociedades anônimas. A sua condição como título de crédito nos levou a considerar aspectos atuais relacionados à teoria geral dos títulos de crédito e o tratamento da matéria pelo Código Civil de 2002. Consequentemente, o exame dessa matéria provocou a reflexão sobre os requisitos do bônus de subscrição reputados como indispensáveis para a sua existência jurídica. Diante das especificidades do bônus de subscrição contrapostas às características dos títulos cambiários, foram ressaltados os elementos daquele que afastam a possibilidade de emissão de bônus de subscrição incompleto.

A decomposição da essência e das particularidades que fundam e discriminam o bônus de subscrição propiciou uma melhor compreensão dos mecanismos que sustentam o título. O direito de subscrição de ações, objeto do bônus de subscrição, também é encontrado em outros instrumentos regulados pela lei de sociedades anônimas, tais como a opção de compra de ações destinada a administradores, empregados e prestadores de serviços e a debênture conversível em ação. Ao investigarmos a finalidade da emissão de cada um desses instrumentos e, também da opção de compra de ações negociada em bolsa de valores, alcançamos uma abordagem diferenciada que nos permitiu explorar as potencialidades práticas e teóricas destes institutos e, em função disso, entender como melhor aplicá-los.

Além disso, ao confrontarmos o bônus de subscrição com outros instrumentos que possuem afinidades com a sua emissão ou aplicação, pudemos identificar traços importantes do objeto de estudo que individualmente não haviam sido evidenciados em toda sua extensão, tais como a formação do preço de subscrição de ações, a natureza da operação resultante do exercício do título, as vantagens da subscrição em face da conversão.

Por meio da pesquisa da lei e da sua interpretação proporcionada pela doutrina, procuramos aproximar os conceitos e as características atribuídos ao bônus de subscrição 
da sua aplicação prática, contribuindo para a construção teórica e para a operacionalidade do instrumento na prática societária.

A propósito do exercício do bônus de subscrição, investigamos a tutela jurídica adequada para remediar a hipótese de inadimplemento da companhia em relação à obrigação de subscrever ações. A execução específica tratada pelos artigos 461 e 644 do Código de Processo Civil foi o procedimento apontado pela doutrina e identificado empiricamente que atende às necessidades do titular de bônus de subscrição quando este não recebe as ações cujo direito de subscrição lhe foi conferido. A análise do caso da Companhia de Bebidas das Américas - Ambev no Capítulo 5 exemplifica concretamente a adaptação do direito material à solução processual, em que pese ainda não ter sido definitivamente julgado pelo Poder Judiciário.

Apesar de pouco difundido e utilizado, o bônus de subscrição consiste em um instrumento útil para a captação de recursos pela companhia e desperta desafios na sua implementação, especialmente frente ao seu uso com o objetivo de diluir a participação de outros acionistas, seja em operações de aquisição de controle ou para viabilizar o aporte de recursos de investidores externos à companhia, conforme identificamos nos casos abordados no Capítulo 5.

Não obstante a agilidade que o caracteriza, o bônus de subscrição não tem sido amplamente utilizado. Segundo apuramos, o volume de negociação deste título na BM\&FBOVESPA é baixo em comparação com o volume total de instrumentos negociados. Parte da explicação dessa realidade pode ser atribuída às características de valor mobiliário não padronizado do bônus de subscrição, o qual não alcança a liquidez no mercado de capitais que os títulos padronizados possuem. Isso porque, este últimos implicam em menores riscos e custos de transação, atraindo mais investidores em decorrência da segurança jurídica que dispões.

Além disso, há uma redução em sua atratividade o fato do bônus de subscrição se sujeitar às limitações inerentes aos títulos emitidos por sociedades anônimas, como o direito de preferência, a vedação à diluição injustificada, parâmetros para fixação do preço de exercícios, entre outros, ressalvadas as hipóteses em que a lei admite convenção em contrário.

Finalmente, alcançamos com o presente trabalho a ampliação do tratamento doutrinário dado ao bônus de subscrição, de modo a contribuir com o fortalecimento de suas bases legais e teóricas. Com o aprimoramento da formulação teórica desse 
instrumento jurídico, esperamos colaborar com a expansão do seu uso ${ }^{306}$, tanto pelas companhias fechadas como por aquelas que participam do mercado de capitais, auxiliando na sua expressão além da previsão legal.

${ }^{306}$ YAZBEK, Otávio. A Modernização do Regime das Debêntures e a Criação de um Mercado de Dívida de Longo Prazo, p. 566. 


\section{BIBLIOGRAFIA}

ABBUD, André de Albuquerque Cavalcanti. O Acordo de Acionistas e a sua Execução Específica. In: CARMONA, Carlos Alberto; AMENDOEIRA JUNIOR, Sidnei (coords.). Direito, Gestão e Prática: Estratégias Processuais na Advocacia Empresarial. São Paulo: Saraiva, 2011.

ALVIM, Arruda; ASSIS, Araken de; ALVIM, Eduardo Arruda. Comentários ao Código de Processo Civil. Rio de Janeiro: GZ Editora, 2012.

AMENDOEIRA JÚNIOR, Sidnei. Tutela jurisdicional de obrigação a declarar vontade e celebrar contrato ("adjudicação compulsória"). In: CARMONA, Carlos Alberto (coord.). Reflexões sobre a reforma do código de processo civil: estudos em homenagem a Ada Pellegrini Grinover, Cândido R. Dinamarco e Kazuo Watanabe. São Paulo: Atlas, 2007.

ARAGÃO, Paulo Cezar. Opções de Compra de Ações e Bônus de Subscrição. In: Revista dos Tribunais, v. 631, p. 63, maio, 1988.

ALLEGRI, Vincenzo. Sull'Impiego del Sopraprezzo d'Emissione degli Azioni. In: Rivista delle Società, n. 6, nov-dez, 1965.

AMARAL, José Romeu Garcia do. Regime Jurídico das debêntures. São Paulo: almedina, 2014.

ASCARELlI, Tullio. Problemas das Sociedades Anônimas e Direito Comparado. São Paulo: Saraiva, 1945.

Teoria Geral dos Títulos de Crédito. Campinas: Servanda, 2009.

BALLANTINE, Henry Winthrop. Ballantine on Corporations, Chicago: Gallaghan and Company, 1927.

BALLANTINE, Henry Winthrop; LATTIN, Norman D.; JENNINGS, Richard W. Cases and materials on corporations. Chicago: Callaghan, 1953.

BATALHA, Wilson de Souza Campos. Sociedades Anônimas e Mercado de Capitais. Rio de Janeiro: Forense, 1973.

BERLE JUNIOR., Adolf Augustus; MEANS, Gardiner Coit. The Modern Corporation and Private Propriety. New York: Macmillan, 1940.

BERLE JUNIOR, Adolf Augustus. Corporate for diluting Stock Participations. In: Columbia Law Review, vol. XXXI, nº 8, 1931.

Studies in the Law of Corporation Finance, Chicago: Callaghan, 1928.

BETES, Miguel A. Sasot. Acciones, bonos, debêntures e obligaciones negociables, Buenos Aires: Ábaco de Rodolfo Depalma, 1985. 
BIMBATO, José Maria. O preço de emissão das ações em aumento de capital. In: Revista de Direito Mercantil, Industrial, Econômico e Financeiro, n. 93, jan./mar., 1994.

BOGEN, Jules I. Corporation Finance. New York: Alexander Hamilton Institute, 1958.

BORBA, José Edwaldo Tavares. Direito Societário. Rio de Janeiro: Renovar, 2001. . Das Debêntures. Rio de Janeiro: Renovar, 2005.

BRUDNEY, Victor. Cases and materials on corporate finance. Mineola: Foundation Press, 1979.

BULGARELLI, Waldirio. Os valores mobiliários brasileiros como títulos de crédito. In: Revista de Direito Mercantil, Nova Série, ano XIX, n. 37, jan./mar., 1980.

. Questões de Direito Societário. São Paulo: Revista dos Tribunais, 1978.

. Títulos de crédito. 11. ed., São Paulo: Atlas, 1995.

CAMPOS, Francisco. Sociedade por Ações: Emissão de Ações com Ágio ou Acima de seu Valor Nominal. Rio de Janeiro: Revista Forense, 1944.

CANTIDIANO, Luiz Leonardo. Direito Societário e Mercado de Capitais. Rio de Janeiro: Renovar, 1996.

CARMONA, Carlos Alberto. Arbitragem e Processo: Um Comentário à Lei n. 9.307/96, 2 ed., rev., atual. e ampl., São Paulo: Atlas, 2004.

CARVAlHOSA, Modesto. Comentários à Lei de Sociedades Anônimas. 5 ed., Saraiva: São Paulo, 2011.

CARVAlHOSA, Modesto; EIZIRIK, Nelson. Estudos de Direito Empresarial. Saraiva: São Paulo, 2010.

CARY, William L.; EISENBERG, Melvin Aron. Cases and Materials on Corporations. 5. ed., Mineola: Foundation Press, 1980.

CASTRO, Carlos Osório de. Valores Mobiliários: Conceitos e Espécies. 2. ed., Porto: Universidade Católica Portuguesa, 1998.

CHARLESWORTH, John. Company Law. 11ª ed. London: Stevens, 1977.

CHEFFINS, Brian. Company Law: theory, structure and operation. Oxford: Clarendon Press, 2005.

CHOPER, Jesse H.; COFFEE JUNIOR., John C.; MORRIS JUNIOR., C. Robert. Cases and Materials on Corporations. 3 ed., Boston: Little, Brown and Company, 1989. 
CINTRA, Maria Lúcia de Araújo. Aspectos jurídicos do bônus de subscrição. São Paulo, Ed. Universidade de São Paulo, 1980.

CLARK, Robert Charles. Corporate Law. Boston: Little, Brown \& Co., 1986.

COMPARATO, Fábio Konder. Novos Ensaios e Pareceres de Direito Empresarial. Rio de Janeiro: Forense, 1981

. O direito de subscrição em aumento de capital no fideicomisso acionário.

In: Revista de Direito Mercantil, n. 40.

A Fixação do Preço de Emissão das Ações no Aumento de Capital de Sociedade Anônima. In: Revista de Direito Mercantil, Industrial, Econômico e Financeiro. n. 81, jan./mar., 1991.

COMPARATO, Fabio Konder; SALOMÃO FILHO, Calixto. O poder de controle na sociedade anônima. Rio de Janeiro: Forense, 2008.

CONARD, Alfred F. Corporations in Perspective. Mineola, Foundation Press, 1976.

CORRÊA-LIMA, Osmar Brina. Sociedade Anônima. 2 ed., Belo Horizonte: Del Rey, 2003.

COSTA, Philomeno Joaquim da. Operações da Anônima com Ações do seu Capital. São Paulo, 1965.

CUNHA, A. Correia da. Acções, Obrigações e outros Valores Mobiliários: coletânea de notas e apontamentos. Lisboa: LCE, 1972.

DALMARTELLO, Arturo. I Rapporti Giuridiche Interni nelle Società Commerciali, Milano: Giuffrè, 1937.

DÉFOSSÉ, Gaston. Les Obligations Convertibles en Actions. Paris: Presses Universitaires de France, 1970.

DINAMARCO, Cândido Rangel. Fundamentos do processo civil moderno, t. 1, 6 . ed., São Paulo: Malheiros, 2010.

2001.

. Instituições de Direito Processual Civil, vol. II, São Paulo: Malheiros,

EASTERBROOK, Frank. The Economic structure of Corporate Law. Cambridge: Harvard University Press, 1996.

EIZIRIK, Nelson. A Lei das S/A comentada. São Paulo: Quartier Latin, 2011.

. Temas de Direito Societário. Rio de Janeiro: Renovar, 2005.

. Aspectos Modernos do Direito Societário Rio de Janeiro: Renovar, 1992. 
EIZIRIK, Nelson L. GAAL, Ariádna B., PARENTE, Flávia; HENRIQUES, Marcus de Freitas. Mercado de Capitais: Regime Jurídico. 3 ed., rev. e ampl., Rio de Janeiro: Renovar, 2011.

ENTERRIA, Le Obbligazioni Convertibili in Azioni. Milão: Giuffrè, 1989.

ERKLENTZ, Enno W. Modern German Corporation. New York: Ocean Publications, 1979.

FERREIRA, Amadeu José. Valores mobiliários escriturais: um novo modo de representação e circulação de direitos. Coimbra: Almedina, 1997.

FOLK, III, Ernest L., The Delaware General Corporation Law: a commentary and analysis. Boston: Little, Brown, 1972.

GARCIA DE ENTERRÍA, Javier. Le Obbligazioni Convertibile in Azioni. Milano: Giuffrè, 1989.

GARNER, Russel D., FORSYTHE, Alfred S. Stock Purchase Warrants and Rights. In: Southern California Law Review, vol. 4, 1930-1931.

GEVURTZ, Franklin A. Business Planning. Westbury: Foundation Press, 1991.

GOMES, Orlando. Contratos. 26 ed., Rio de Janeiro: Forense, 2009.

GOWER, L.B.C; DAVIES, Paul. Gower \& Davies' Principles of Modern Company Law. $9^{\mathrm{a}}$ ed., London: Sweet and Maxwell, 2012.

GREENSPAN, Alan. Stock Options and Related Matters. In: WALD, Arnoldo. Doutrinas Essenciais: Direito Empresarial, v. 3, São Paulo: Revista dos Tribunais, 2011.

GUERREIRO, José Alexandre Tavares. Regime Jurídico do Capital Autorizado. São Paulo: Saraiva, 1984.

. Sobre opção de compra de ações. In: Revista de Direito Mercantil, Industrial, Econômico e Financeiro. São Paulo: Revista dos Tribunais, v. 39, jul./set., 1980.

Execução Específica do Acordo de Acionistas. In: Revista de Direito Mercantil, São Paulo: Revista dos Tribunais, v. 41, jan./mar., 1981.

O conselho fiscal e o direito a informação, In: Revista de Direito Mercantil, Industrial, Econômico e Financeiro, São Paulo: Revista dos Tribunais, v. 45, jan./mar., 1982

GURSKY, Karl-Heinz. Wertpapierrecht. C.F. Müller, 2007.

HAMILTON, Robert W. The Law of Corporations. 5 ed., St. Paul: West Group, 2000. 
HENN, Harry G; ALEXANDER, John R. Law of corporations and other business enterprises. 2 ed., St. Paul: West Publishing, 1983.

HOVASSE, Henri, Les Augmentations de capital a souscription conditionelle, Paris: Économica, 1988.

HULL, John C., Options, futures and other derivatives, 7 ed., Pearson Prentice Hall: Upper Saddle River (New Jersey), 2009.

IGLESIAS, Felipe Campana Padin. As opções de compra ou venda de ações no direito brasileiro: natureza jurídica e tutela executiva judicial. Dissertação de mestrado, Orientador Professor José Alexandre Tavares Guerreiro, Faculdade de Direito da Universidade de São Paulo, 2013.

ISRAELS, Carlos L. Corporate Practice. 3 ed. New York: Practising Law Institute, s.d.

JENNINGS, Richard W.; MARSH JUNIOR, Harold; SELIGMA, Joel. Securities Regulations. Foundation Press, 1998.

JOHNSON JUNIOR, Charles J.; MCLAUGHLIN, Joseph. Corporate Finance and the Securities Laws. $3^{\text {a }}$ ed. New York: Aspen Publishers, 2004.

KAPLAN, Stanley A. Piercing the corporate boilerplate: anti-dilution clauses in convertible securities. In: The University of Chicago Law Review, vol. 33, nº 1, 1965.

KEITH, Clifford Charles. Convertible Securities and Stock Purchase Warrants. In: Rocky Mountain Law Review, vol. 2, 1929-1930.

KOHLER, Claudio. Bônus de Subscrição. In: Revista dos Tribunais. São Paulo: Editora Revista dos Tribunais, v. 641, março, 1989.

LAMY FILHO, Alfredo; PEDREIRA, José Luiz Bulhões (coord.). Direito das Companhias. Rio de Janeiro: Forense, 2009.

LATTIN, Norman Dunhan. The Law of Corporations. Mineola: Foundation Press, 1971.

LEÃS, Luis Gastão Paes de Barros. Estudos e Pareceres sobre Sociedades Anônimas. São Paulo: Revista dos Tribunais, 1989.

LE GALL, Jean Pierre. French Company Law. London: Oyez Publishing, 1974.

LOBO, Jorge. Direto dos Acionistas. Rio de Janeiro: Elsevier, 2011.

LOPES, Mauro Brandão. S/A: Títulos e Contratos Novos. São Paulo: Revista dos Tribunais, 1978.

LOSS, Louis. Securities Regulation. Boston: Little Brown, 1951.

MARQUES, José Frederico. Instituições de Direito Processual Civil. vol. I, Campinas: Millennium, 2000. 
MARINONI, Luiz Guilherme; ARENDHART, Sérgio Cruz. Curso de Processo Civil, vol. 2, 11 ed., rev. e atual, São Paulo: Revista dos Tribunais, 2013.

MARTINS, Fran. As sociedades de capital autorizado na nova lei das sociedades anônimas. In: Revista de Direito Mercantil, n. 26, São Paulo: Malheiros, 1977.

Comentários à Lei das Sociedades Anônimas. 4 ed., rev. e atual., Rio de Janeiro: Forense, 2010.

MASCHERONI, Fernando H. Capital Social y acciones nominativas. Buenos Aires: Cangallo, 1974.

Buenos Aires: Cangallo, 1970.

. El Vínculo Accionista: Sociedade Anónima y El Contrato de Suscripción.

MATTOS FILHO, Ary Oswaldo de. O Conceito de Valor Mobiliário. In: Revista de Administração de Empresas, Rio de Janeiro: Fundação Getúlio Vargas, n. 25, abr./jun

MENDONÇA, José Xavier Carvalho de. Tratado de Direito Comercial Brasileiro. Rio de Janeiro, Freitas Bastos, 1948.

MICCIO, Renato. Il diritto di opzione nell'aumento di capitale delle società per azioni. Napoli: Jovene, 1957.

MIRANDA, Pontes de. Tratado de Direito Privado: Direito das Obrigações, Negócios Jurídicos Bancários e de Bôlsa, Corretagem de Seguros, Transferência de Propriedade Mobiliária, em Segurança, Subscrição, Distribuição e Colocação de Títulos e Valores Mobiliários, t. 52, atualizado por Bruno Miragem, São Paulo: Revista dos Tribunais, 2012

Tratado de Direito Privado: Direito das Obrigações, Sociedades por Ações, t. 50, atualizado por Alfredo de Assim Gonçalves Neto, São Paulo: Editora Revista dos Tribunais, 2012.

. Comentários ao Código de Processo Civil, t. 5, 3. ed., rev., e aum., atualização legislativa de Sergio Bermudes, Rio de Janeiro: Forense, 1997

MITCHELL, Lawrence E; SOLOMON, Lewis D. Corporate Finance and Governance: Cases, Materials and Problems for an Advanced Course in Corporations. Durham: Carolina Academic Press, 1992.

MOREIRA, José Carlos Barbosa. O novo processo civil brasileiro, vol. II, 29 ed., Rio de Janeiro: Forense, 2012.

MORSE, Geoffrey; WORTHINGTON, Sarah, (editores). Palmer's Company Law: annotated guide to The Companies Act 2006. Londres: Sweet \& Maxwell, 2008.

MUNHOZ, Eduardo Secchi. A importância do sistema de solução de conflitos para o direito societário: limites do instituto da arbitragem. In: YARSHELL, Flávio Luiz; PEREIRA, Guilherme Setoguti J. Processo Societário, São Paulo: Quartier Latin, 2012. 
MUSSNICH, Francisco Antunes Maciel. As recentes alterações com respeito à competência para emissão de debêntures. In CASTRO, Rodrigo Rocha Monteiro de; WARDE JÚNIOR, Walfrido Jorge; GUERREIRO, Carolina Dias Tavares. Direito Empresarial e outros estudos de direito em homenagem ao Professor José Alexandre Tavares Guerreiro. São Paulo: Quatier Latin, 2013.

NERY JUNIOR, Nelson; NERY, Rosa Maria de Andrade. Código de processo civil comentado e legislação extravagante. $13^{\mathrm{a}}$ ed., rev., atual. e ampl., São Paulo, Revista dos Tribunais, 2013.

NESS, Theodore. Corporate Stock. In: Financial Handbook. New York: Ronald Press Company, 1968.

NICKLES, Steve H. Negotiable Instruments and related commercial papers. Eagen: West Publishing, 1993.

NOBILI, Raffaele. Contributo allo Studio del Diritto d'Opzione nelle Società per Azioni. Milano: Giuffrè. 1957.

OCHMAN, Renato. Atos Societários Relevantes: a Companhia e os Investidores. São Paulo: Impressão Régia, 2013.

PALMER, Fancis Beaufort. Palmer's Company Law. 20 ed. London: Stevens, 1959.

PASTERIS, Carlo. L'Emissione di Azioni com Sopraprezzo. In: Rivista delle Società, fasc. $1,1962$.

PEDREIRA, José Luiz Bulhões; LAMY FILHO, Alfredo. A Lei das S.A.: Pressupostos, Elaboração, Aplicação. Rio de Janeiro: Renovar, 1992.

PENTEADO, Mauro Rodrigues. Aumentos de Capital das Sociedades Anônimas. São Paulo: Saraiva, 1988.

PENTEADO, Mauro Rodrigues (coord.). Títulos de crédito. São Paulo: Walmar, 2004.

PEREIRA, Caio Maio da Silva. Instituições de Direito Civil, vol. III, 11. Ed., Rio de Janeiro: Forense, 2004,

PINTO JUNIOR, Mario Englert. A capitalização da companhia, In: FINKELSTEIN, Maria Eugênia Reis e PROENÇA, José Marcelo Martins (coords.). Sociedades Anônimas, 2. ed., São Paulo: Saraiva, 2011.

PUOLI, José Carlos Baptista. Os Poderes do Juiz, a Tutela Processual Específica e o Direito Societário. In: YARSHELL, Flávio Luiz; PEREIRA, Guilherme Setoguti J. (Coords.). Processo Societário, São Paulo: Quartier Latin, 2012.

RADIN, Stephen A. The Business Judgement Rule: Fiduciary of Corporate Directors. vol. I, 6. ed., Wolters Kluwer Law \& Business/Aspen Publisher, 2009. 
REILING, Henry B. Warrants in Bond-Warrants Units: A Survey and Assessment. In: Michigan Law Review, n. 70, 1971-1972.

RIZZARDO, Arnaldo. Títulos de Crédito. Rio de Janeiro: Forense, 2006.

ROMANO, Roberta. Foundations of Corporate Law. New York: Foundation Press, 1993.

ROSSET, Paul René, Les Titres Américains, R. Pichon \& Durand-Auzias: Paris, 1931.

SALOMÃO FILHO, Calixto. O novo direito societário. 4. ed., rev. e ampl., São Paulo: Malheiros, 2011.

SÁNCHEZ ANDRÉS, Aníbal. El derecho de suscripción preferente del accionista. Madrid: Civitas, 1973.

SEALY, Len; WORTHINGTON, Sarah. Cases and materials in Company Law. $8^{\mathrm{a}}$ ed. New York: Oxford, 2008.

SILVA, João Paulo Hecker da. Processo Societário: Tutelas de Urgência e da Evidência. Brasília: Gazeta Jurídica, 2014.

SPINELLI, Luis Felipe. Os títulos de crédito eletrônicos e as suas problemáticas nos planos teórico e prático. In: Revista do Ministério Público do Rio Grande do Sul, Porto Alegre, n. 67, set./dez., 2010.

SOUZA JUNIOR, Francisco Satiro de. Regime Jurídico das Opções Negociadas em Bolsas de Valores, Tese de doutorado, Orientador Professor Waldírio Bulgarelli, Faculdade de Direito da Universidade de São Paulo, 2002.

TEIXEIRA, Egberto Lacerda; GUERREIRO, José Alexandre Tavares. Das Sociedades Anônimas no Direito Brasileiro. São Paulo: José Bushatsky Editor, 1979.

TEIXEIRA, Egberto Lacerda. Os Aumentos de Capital e o Direito dos Portadores de Ações Preferenciais. In: Revista dos Tribunais. v. 43, n. 220, São Paulo, Revista dos Tribunais, fev., 1954.

A Conversão de Debêntures em Ações e o Aumento do Capital Social. In: Revista de Direito Mercantil, Industrial, Econômico e Financeiro, n. 54, abr./jun., 1984.

TEIXEIRA, Sálvio de Figueiredo (coord.). Comentários ao novo código civil, vol. XII, Rio de Janeiro: Forense, 2003.

VALLADÃO, Erasmo Azevedo e Novaes França; ADAMEK, Marcelo Vieira von. Da Invalidade da Deliberação Assemblear Contrastante com as Regras de Fixação do Preço de Emissão de Ações (LSA, Art. 170, $1^{\circ}$ ). In: Revista de Direito Mercantil, Industrial, Econômico e Financeiro, n. 161/162, ano LI (nova série), jan./ago., São Paulo: Malheiros, 2012.

VALUET, Jean-Paul, Stock Options, Paris: Joly editions, 1997. 
VALVERDE, Trajano de Miranda. Sociedades por Ações. Rio de Janeiro: Forense, 1953.

VELASCO SAN PEDRO, Luis Antonio. El Derecho de Suscripción Preferente. In Derecho de Sociedades Anónimas: Estudios coordinados por Alberto Alonso Ureba y otros. Madrid: Civitas, 1991.

VERÓN, Alberto Víctor. Sociedades Comerciales, Tomo 3, Buenos Aires: Astrea, 1998, p. 662-663.

YARSHELL, Flávio Luiz. Tutela jurisdicional específica nas obrigações de declaração de vontade. São Paulo: Malheiros Editores, 1993.

YAZBEK, Otávio. A Modernização do Regime das Debêntures e a Criação de um Mercado de Dívida de Longo Prazo. In: CASTRO, Rodrigo Rocha Monteiro de; WARDE JÚNIOR, Walfrido Jorge; GUERREIRO, Carolina Dias Tavares. Direito Empresarial e outros estudos de direito em homenagem. ao Professor José Alexandre Tavares Guerreiro. São Paulo: Quatier Latin, 2013 


\section{RELAÇÃO DE JULGADOS CONSULTADOS}

Comissão de Valores Mobiliários. Processo CVM n. RJ2009/9251, Reg. Col. n. 6740/2009, Relator Diretor Marcos Barbosa Pinto, 17 de novembro de 2009.

Comissão de Valores Mobiliários. Processo CVM n. SP 2002/0474, Reg. Col. n. 3948/2002, Relatora Diretora Norma Jonssen Parente, 31 de março de 2003.

Comissão de Valores Mobiliários. Processo CVM n. RJ 2011/1532, Reg. Col. n. 7671/2011, Relator Diretor Eli Loria, 14 de junho de 2011.

Comissão de Valores Mobiliários. Processo CVM n. RJ 2008/11861, Reg. Col. n ${ }^{\circ}$ 6366/2009, Relator Diretor Eli Loria, 03 de março de 2009.

Comissão de Valores Mobiliários. Processo CVM n. RJ 2002/2935, Reg. no 3764/02 Relatora Diretora Norma Jonssen Parente, 10 de outubro de 2002.

Comissão de Valores Mobiliários. Processo CVM n. RJ 2006/645, Ata da reunião do colegiado n. 05, Reg. Col. n. 5020/06, 07 de fevereiro de 2006.

Comissão de Valores Mobiliários. Processo CVM n. RJ 2003/11177, Reg. Col. n. 4230/2003, Relator Diretor Luiz Antonio de Sampaio Campos, 04 de novembro de 2003.

Tribunal de Justiça do Rio de Janeiro. Terceira Câmara Cível, Relator Desembargador Antônio Eduardo F. Duarte, Apelação Cível no 0047299-63.2003.8.19.0001, 28 de agosto de 2007.

Superior Tribunal de Justiça. Quarta Turma, Recurso Especial n. 717.327, Relator Ministro Cesar Asfor Rocha, 27 de março de 2006.

Superior Tribunal de Justiça. Quarta Turma, Recurso Especial n. 1.190.755, Relator Ministro Luis Felipe Salomão, julgado em 21 de junho de 2011. 